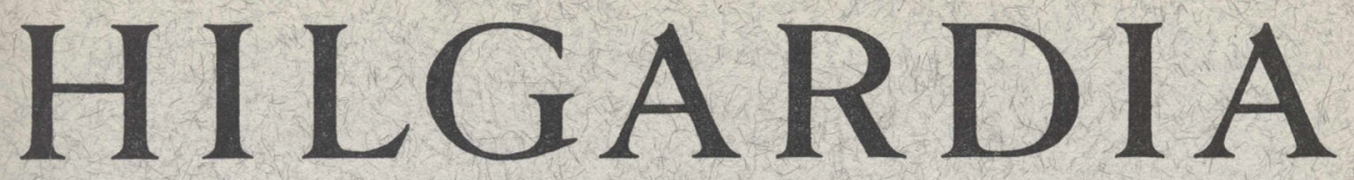

A Journal of Agricultural Science Published by the California Agricultural Experiment Station

\title{
ECONOMIES OF SCALE FOR EVAPORATED MILK PLANTS IN CALIFORNIA
}

JAMES N. BOLES 
The primary objective of this report is to estimate the relationship between unit cost of processing evaporated milk and scale or capacity of plant. A secondary objective is to estimate the relationship between unit cost of processing evaporated milk and output rate for each of several specific plants.

The study is limited in scope. Evaporated milk plants considered here receive whole milk from regular patrons, produce a single product, and possess a common technology and operating environment typical of California plants. Only in-plant costs are analyzed. Costs incurred in the purchase and assembly of the raw product are not included, nor are the costs of distribution and sale of the final product. 


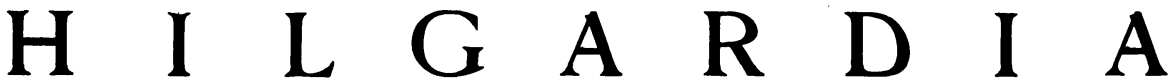

A Journal of Agricultural Science Published by

the California Agricultural Experiment Station

\section{ECONOMIES OF SCALE FOR EVAPORATED MILK PLANTS IN CALIFORNIA ${ }^{1}$}

\author{
JAMES N. BOLES 2
}

\section{Section I}

\section{INTRODUCTION}

"In the decade between 1940 and 1950, the population in the Western Region has increased by more than 40 per cent, which is roughly the equivalent of one third of the increase which occurred throughout the United States as a whole. This increase-representing approximately $5,700,000$ additional consumers of dairy products-is about the same as the total combined population of the states of Minnesota and Iowa. During the same period of time, the production of milk in the region increased by only 10 per cent, which has meant that certain drastic changes have been required in the nature of the dairy industry in the region. A relatively larger proportion of the total milk produced has been used for fluid milk products, and where, in the past, the region has been in a surplus position with respect to most manufactured dairy products-most notably butter - many of these products are now being shipped into the region from the Midwest.

"Furthermore, as the development of large new irrigated agricultural areas nears completion, the region faces the problem of how to establish the most efficient system of marketing facilities within these new areas. It has been estimated that within the next 30 years, $2,000,000$ acres of irrigated land will be added to the resources of the region. In the Columbia Basin project alone, 500,000 acres will be available within five years. A study made by the Bureau of Agricultural Economics has indicated that about one half of this new land (250,000 acres) will probably be devoted to dairy production

${ }^{1}$ Submitted for publication May 28, 1957.

${ }^{2}$ Assistant Professor of Agricultural Economics and Assistant Economist in the Experiment Station and on the Giannini Foundation, Berkeley. 
and that this new land will potentially produce about one half as much again the amount of dairy products now being produced in the state of Washington."

These paragraphs were taken from the annual report for 1951 of the Western Region Dairy Technical Committee. The rapid and drastic changes in population, milk production, and utilization which have occurred or are expected to occur have confronted the dairy industry in the Western Region (consisting of 11 states: Montana, Wyoming, Colorado, New Mexico, and those states farther west) with a series of difficult problems. The degree to which the industry can properly adjust to the changed and changing environment, in order to provide a more efficient ${ }^{3}$ marketing system for manufactured dairy products, is strongly conditioned by the amount of relevant information available. The Committee has sponsored research and publication of findings in three general areas: (1) reporting and forecasting changes in population, milk production, and utilization; (2) analyzing the complex interrelationships in the marketing of manufactured dairy products-interregional, interproduct, and intertemporal price relationships and their basic causes; and (3) analyzing what have been called "cost and efficiency" relationships in processing plants. The present study belongs in this third category.

Previous work of this kind has been published concerning butter-nonfat dry milk plants in the Pacific Northwest ${ }^{4}$ and cheese plants in Oregon. ${ }^{5}$ The results of these studies are applicable, at least in large part, to similar plants in other areas of the Western Region or even in other regions. The choice of areas was made on the basis of: (1) the existing intraregional specialization in manufactured dairy products, and (2) the increase in both travel time and cost if plants were studied in all parts of the Western Region.

California was the leading producer of evaporated milk in the Western Region in 1955, producing 55 per cent of the total regional output. Eleven plants were currently producing evaporated milk in California, while the largest number in any other state in the Western Region was four. One prerequisite for evaporated milk production is an area where the average production per acre of manufacturing milk is relatively large, since evaporated milk plants tend to be of greater capacity than plants designed to produce other manufactured dairy products from whole milk. This condition is satisfied in parts of California but so is it satisfied in several other states in the Western Region. Existing intraregional specialization is due primarily to the large

${ }^{3}$ For extended discussions of marketing efficiency, see Hassler, James B., "Pricing Efficiency in the Manufactured Dairy Products Industry," in Hilgardia 22(8):235-334, August, 1953 ; and Bressler, R. G., "Efficiency in the Production of Marketing Services." Soc. Sci. Res. Coun. Proj. in Agr. Econ., Economic Efficiency Series Paper No. 6; 67 pp. Chicago. Crudely put, the concept of economic efficiency involves: (a) the production of space, form, and time utilities to conform, subject to technological and cost considerations, to ultimate consumer demands and (b) the performance of this function at minimum cost. See "Bibliography" at the end of this study.

"Walker, Scott H., Homer J. Preston, and Glen T. Nelson. "An Economic Analysis of Butter-Nonfat Dry Milk Plants." Idaho Agr. Exp. Sta. Res. Bul. 20. 90 pp. 1953.

${ }^{5}$ Rowe, Gordon A. "Economics of Cheese Manufacturing in Tillamook County, Oregon." Oregon Agr. Exp. Sta. Bul. 529. 31 pp. 1952. See also Nelson, Glen T. "Whether to Manufacture Butter and Powder . . o or Cheese.” Oregon Agr. Exp. Sta. Bul. 546:1-9. 1954. 
population of California relative to other states, coupled with the fact that evaporated milk is not so concentrated a product as butter or cheese and thus tends to be produced nearer the consumption centers.

The foregoing discussion serves as a background for two decisions that were made: (1) that the California Agricultural Experiment Station be given the primary responsibility in exploring the cost and efficiency relationships in evaporated milk plants, and (2) that the technology and operating characteristics of California plants furnish the basis for an analysis of plant costs.

The method of analysis is similar to that of the architect or engineer. Costvolume relationships are estimated for each of six hypothetical plants similar in all respects except in their eight-hour capacity to process evaporated milk. In order to estimate costs using this method it is necessary to select equipment for each plant, to prepare rough sketches of equipment layouts, and to determine approximately the sizes of the buildings required. The resulting plant designs are not comparable with the final detailed designs prepared by an engineer or architect. They are preliminary designs for cost estimation. Minor modifications in equipment selection or layout might be made with relatively little effect on cost-volume relationships.

\section{Section II}

\section{OPERATING CONDITIONS}

To isolate the effect of a change in the scale of plant on unit processing costs, it is necessary to specify certain characteristics and operating conditions common to each plant studied. Except where noted otherwise, the specifications are typical of California plants currently producing evaporated milk.

\section{Product Specification and Standardization}

In order to avoid the problems of allocating joint costs to each of several products, all of the plants studied produce a single product, cases of evaporated milk, each case containing forty-eight $141 / 2$-ounce cans. (This is not typical of California plants. Most of them also produce cases containing 96 six-ounce cans, while several produce a wide variety of other products.)

Federal standards require evaporated milk entering into interstate commerce to contain by weight at least 7.9 per cent $F$ (fat) and 25.9 per cent TS (total solids). To provide for experimental error, most plants standardize at slightly higher levels. Consequently, 7.93 per cent $F$ and 26.1 per cent TS are the standards used here.

For a similar reason, can filling equipment is generally set to slightly exceed the specified content per can. The standard used here is an average of one gram overfill per can. Thus a case of product contains 43.6 pounds of evaporated milk. (Forty-eight cans, each containing 141/2 ounces, would require 696 ounces of product. Forty-eight grams of product are equivalent to 1.69 ounces, making a total of 697.69 ounces or 43.6 pounds of evaporated milk per case.)

During most of the year in California, the fat content of the milk received is in excess of the amount required to insure the proper ratio between $\mathrm{F}$ and 
TS in the final product. For at least 10 months of the year, then, plant managers have a choice between purchasing additional SNF (solids-not-fat) in the form of some concentration of skim milk or separating a portion of the milk received, selling the cream, and standardizing the remaining milk with the resulting skim milk. If standardization is accomplished by purchasing skim milk or cream from other sources, the plant does not need to install equipment or provide labor to separate milk and to pasteurize and market the resulting cream or skim milk. Most California plants are multipleproducts plants and are therefore equipped to standardize using either method. For simplicity in analysis, all plants studied here standardize with purchased 32 per cent SNF concentrated skim milk and 30 per cent $F$ cream.

\section{Characteristics of Milk Supply and Utilization}

California evaporated milk plants receive most of their milk from regular patrons producing manufacturing grade milk. At various times, liowever, milk is received from other than regular patrons. The amounts so received vary from plant to plant and from time to time in response to changing price relationships between the various manufactured dairy products and/or changing inventory positions. Again for simplicity, for the purposes of this study, all plants receive milk only from regular patrons.

They receive whole milk daily in 10-gallon cans directly from these regular patrons. All of them receive milk twice per day during the summer months; most of them receive milk twice per day all year. The standard specified here is that all plants receive whole milk in 10-gallon cans twice daily with approximately the same volume per shift except the smallest plant which receives once per day during the period from November through January. (At least two men per shift are required for the receiving operation by all the plants except the smallest, which requires only one. Other plants adjust to a decreased volume of receipts by reducing the size of crew; the smallest plant adjusts by reducing the number of shifts per day.)

Additional specifications for milk receipts are:

(1) There are no cooling facilities on farms so that milk is at approximately air temperature when received. Air temperatures used are monthly average maximum temperatures recorded at Fresno by the United States Weather Bureau (Table 1). (This specification is used to estimate refrigeration requirements. Minor variations in temperature specifications would not alter appreciably the results.)

(2) The average shipment per producer during the flush season is 250 pounds of whole milk per shift or 500 pounds per day.

(3) The average weight of whole milk per can is 65 pounds.

(4) During the flush season, 85 per cent of the producers ship less than 500 pounds of whole milk per shift, 10 per cent ship more than 500 but less than 1,000 pounds per shift, while the remaining 5 per cent averages 2,000 pounds per shift. (The figures shown in (2), (3), and (4) were derived from data collected from one California plant. While these figures may not be representative of other plants, alternative values would not alter appreciably the final results.) 
Both the quantity and composition of milk receipts vary during the year. For the purposes of this study, variation in the quantity of milk receipts can be reasonably represented by the average seasonality of the total amount of manufacturing milk purchased from producers. Using data from the period 1946 through 1952, a seasonal index of quantity variation was computed (Table 2). The figures show the average percentage each month's quantity is of the average amount received per month. Thus, for example, if the average amount of whole milk received per month is 100,000 pounds $-75,000$ would be received in January; 132,000 in May; and 87,000 in October.

\section{TABLE 1 \\ AVERAGE MAXIMUM TEMPERATURE, FRESNO, CALIFORNIA}

\begin{tabular}{|c|c|}
\hline Month & $\begin{array}{c}\text { Degrees } \\
\text { Fahrenheit }\end{array}$ \\
\hline January ................ & 54.3 \\
\hline February $\ldots \ldots \ldots \ldots \ldots \ldots \ldots \ldots \ldots \ldots \ldots \ldots$ & 61.4 \\
\hline 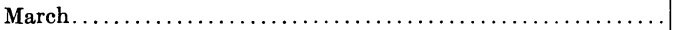 & 66.0 \\
\hline April $\ldots \ldots \ldots \ldots \ldots \ldots \ldots \ldots \ldots \ldots \ldots \ldots \ldots \ldots \ldots$ & 73.6 \\
\hline May..$\ldots \ldots \ldots \ldots \ldots \ldots$ & 81.3 \\
\hline June............ & 91.2 \\
\hline July $\ldots \ldots \ldots \ldots \ldots \ldots \ldots$ & 99.0 \\
\hline August............... & 97.3 \\
\hline September............ & 89.0 \\
\hline October..... & 78.4 \\
\hline November........... & 66.5 \\
\hline December............... & 54.8 \\
\hline
\end{tabular}

Source: U. S. Weather Bureau. Summary of the Climatological Data for the United States by Sections. Section 15-18, California. (1934 edition.)

The only component of milk receipts tested is milk fat. Using data from 1948 through 1952, the average fat test of milk received at California condenseries was calculated for each month (Table 2).

Although no tests are made for the SNF component, it can be estimated by the following equation which expresses the average relationship between the $\mathrm{F}$ and SNF percentages of the California milk supply.

$$
\mathrm{SNF}=7.07+0.444 \mathrm{~F}^{8}
$$

Using this equation and the average $\mathrm{F}$ tests listed previously, the corresponding average SNF percentages were calculated (Table 2 ).

Due to the seasonal variation in milk composition, there is also a seasonal variation in the quantity of evaporated milk which can be produced from a given quantity of whole milk. Using the specifications and data from the preceding sections, monthly conversion rates were calculated (Table 3 ).

The seasonal index of milk receipts and seasonal conversion rates are used to estimate monthly and annual production of evaporated milk and average daily production of evaporated milk for each of the six plants to be studied. Table 8 specifies the average quantity of whole milk received per day during May for each plant.

${ }^{6}$ E. L. Jack, E. B. Roessler, F. H. Abbott, and A. W. Irwin, "Relationship of Solidsnot-fat to Fat in California Milk." Calif. Agr. Exp. Sta. Bul. 726:6. 1951. 


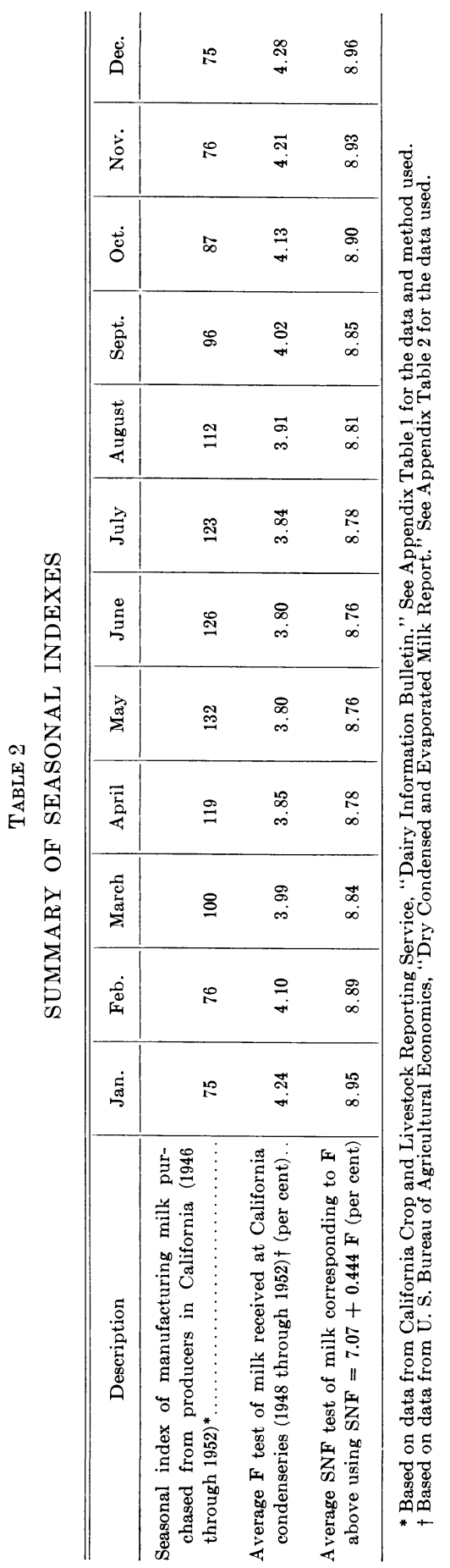




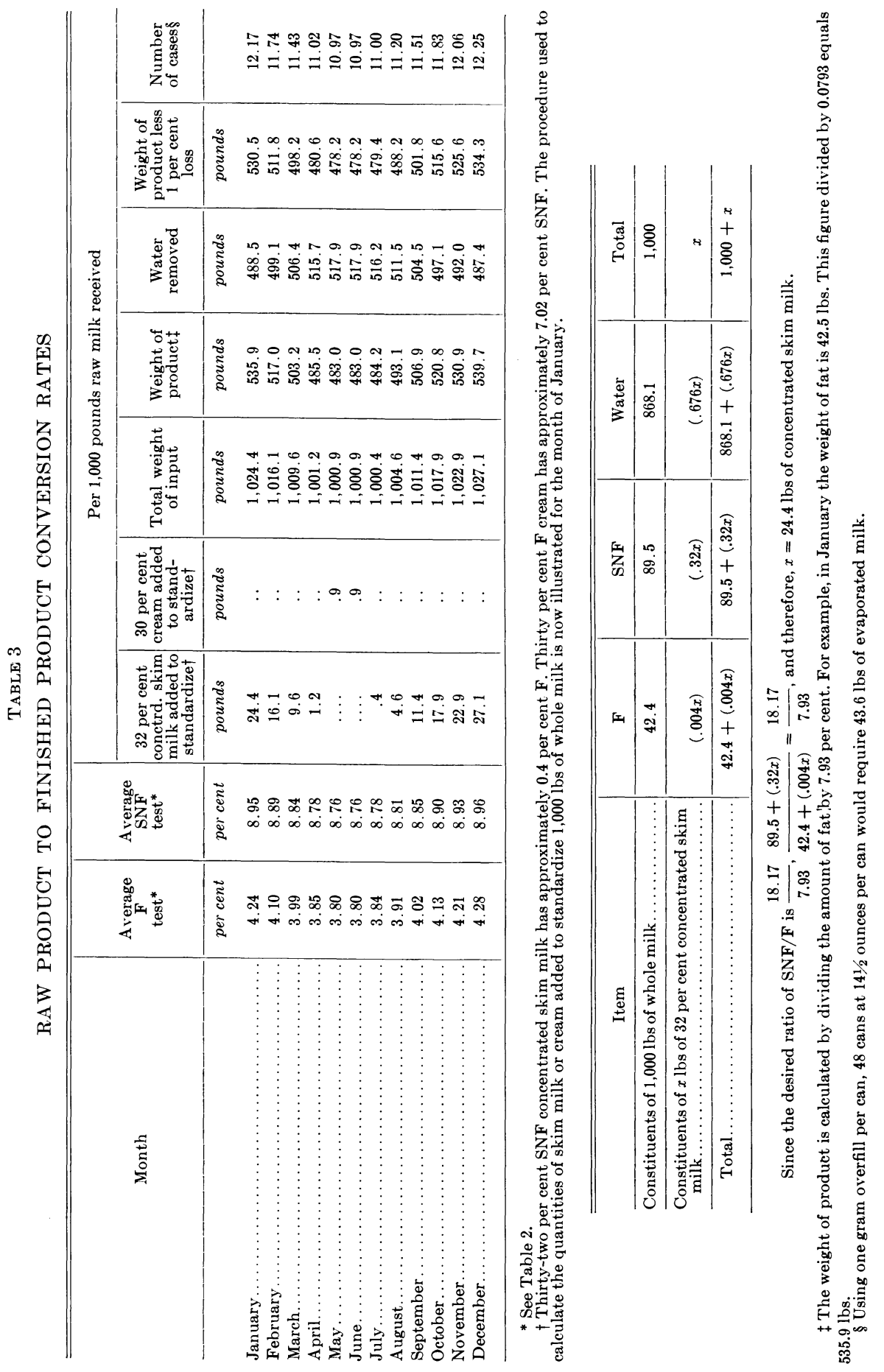


Plant I receives an average of 146,000 pounds of milk per day during May. This is equivalent to total May receipts of 4,526,000 pounds of whole milk. Using a conversion rate for May of 10.97 cases of evaporated milk per thousand pounds of whole milk, this is equivalent to 49,650 cases of evaporated milk per month or an average of 1,600 cases of evaporated milk per day.

The seasonal index of milk receipts is used to estimate total receipts of whole milk by Plant I for each of the other months. The seasonal index for March is 100 while that for May is 132 . Thus, March receipts are estimated

\section{TABLE 4}

ESTIMATION OF MONTHLY AND ANNUAL PRODUCTION AND AVERAGE DAILY PRODUCTION OF EVAPORATED MILK FOR PLANT I

\begin{tabular}{|c|c|c|c|c|c|}
\hline Month & $\begin{array}{c}\text { Seasonal } \\
\text { index of milk } \\
\text { receipts* }\end{array}$ & $\begin{array}{l}\text { Monthly } \\
\text { milk } \\
\text { receipts } \dagger\end{array}$ & $\begin{array}{c}\text { Converson } \\
\text { rates } f\end{array}$ & $\begin{array}{c}\text { Evaporated } \\
\text { milk } \\
\text { production§ }\end{array}$ & $\begin{array}{c}\text { Average } \\
\text { daily } \\
\text { production }\end{array}$ \\
\hline & & $1,000 \mathrm{lbs}$ & $\begin{array}{c}\text { cases per } \\
1,000 \mathrm{lbs}\end{array}$ & 1,000 cases & cases \\
\hline January . . . . . . & 75 & 2,572 & 12.17 & 31.30 & 1,010 \\
\hline March...... & 100 & 3,429 & 11.43 & 39.19 & 1,260 \\
\hline April. . & 119 & 4,080 & 11.02 & 44.96 & 1,500 \\
\hline May......... & 132 & 4,526 & 10.97 & 49.65 & 1,600 \\
\hline June......... & 126 & 4,320 & 10.97 & 47.39 & 1,580 \\
\hline July . . . . . . . & 123 & 4,217 & 11.00 & 46.39 & 1,500 \\
\hline December $\ldots \ldots \ldots \ldots \ldots \ldots \ldots$ & 75 & 2,572 & 12.25 & 31.51 & 1,020 \\
\hline Annual. . & . & $\ldots \ldots$ & $\ldots \ldots$ & 468.60 & 1,280 \\
\hline
\end{tabular}

* See Table 2.

† The May figure is obtained by multiplying 146,000 lbs per day by 31 days. The March figure is obtained by dividing the figure for May by the index for May. The remaining figures are obtained by multiplying the March figure by the corresponding monthly index.

t See Table 3 .

$\$$ Product of entries in preceding two columns. Figures are rounded.

Entry in previous column divided by number of days per month. Figures are rounded.

by dividing May receipts by 132 . Receipts for other months are estimated by multiplying the March receipts by the seasonal index of the corresponding months. Table 4 summarizes the results for Plant I.

Table 5 lists estimated monthly receipts and average daily receipts of whole milk for each month for each plant. Table 6 lists monthly and annual production and average daily production of evaporated milk for each plant.

\section{Labor Agreement}

Wage rates and certain working conditions in California plants producing manufactured dairy products are determined by collective bargaining between the Milk Products Manufacturers' Association and local unions whose collective bargaining agent is the International Brotherhood of Teamsters, Chauffeurs, Warehousemen, and Helpers of America. 


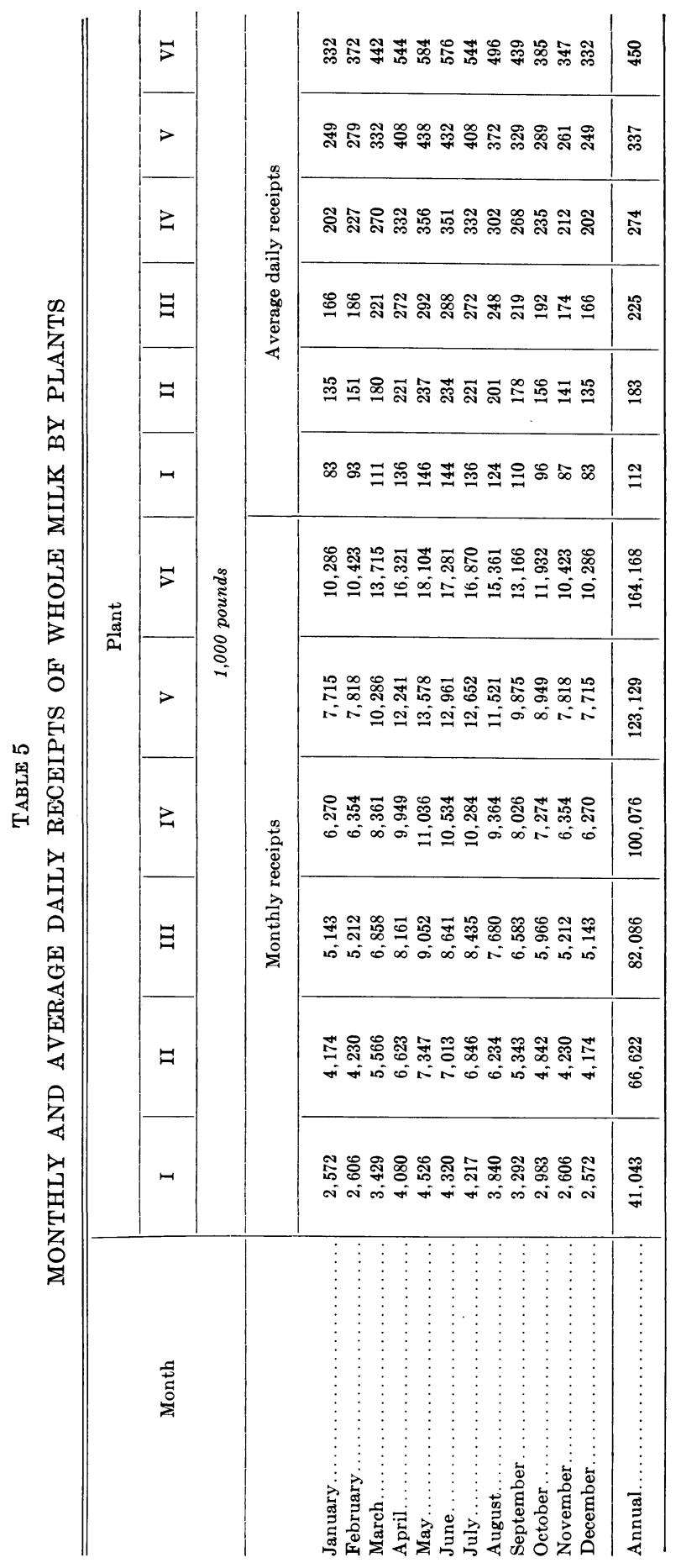




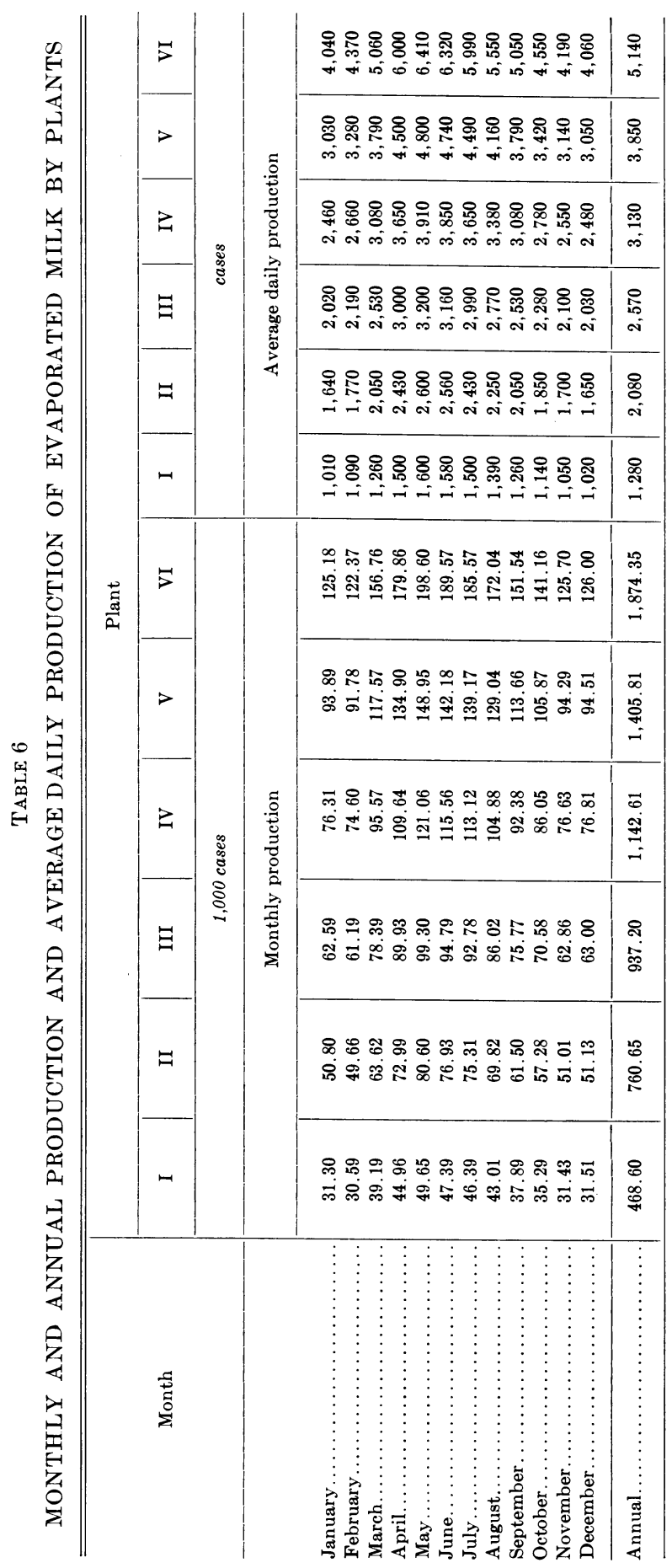


The 1953 agreement specifies the following categories and hourly rates:

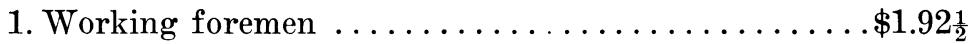

2. Skilled relief men .................... 1.87

3. Maintenance men ...................... 1.87

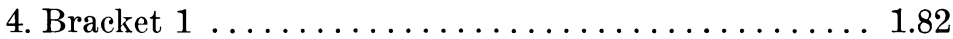

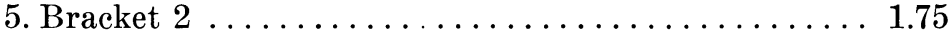

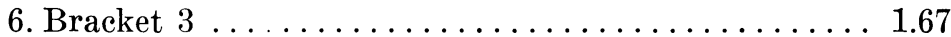

Skilled relief men are those men working on Bracket 1 jobs on two or more shifts during the week or in two or more classifications or outside their regular classification.

Job classifications in Bracket 1 for evaporated milk plants are: testers (Babcock or Mojonnier); shipping clerks or receiving clerks; receivers, weighers or samplers of milk and cream; operators of vacuum pans, sterilizers, can fillers, and power lift trucks; casers and labelers; and relief men working in jobs classified as Brackets 2 or 3 .

Job classifications in Bracket 2 are machine operators not listed in Bracket 1 , cleaners and sterilizers of milk line and processing equipment, and maintenance helpers.

Job classifications in Bracket 3 include all others not listed above except office employees. Categories and monthly salaries for office employees are:

1. Junior clerk . . . . . . . . . . . . . . . . . . . . . \$197.65

(New hires may be employed at $\$ 10.00$ below scale for first 90 days.)

2. Intermediate clerk . . . . . . . . . . . . . 222.65

3. Senior clerk ...................... 252.65

4. Principal clerk ..................... 282.65

(Office employees in classifications other than junior clerk may be started at $\$ 20.00$ below seale for first 90 days.)

Other major sections of the 1953 agreement which directly affect labor costs follow.

"Hours. Not more than forty (40) hours shall constitute a week's work, to be completed within five (5) days, with time and one-half paid for all hours worked above eight (8) hours within nine (9) consecutive hours in any one day, or forty (40) hours in any one week, whichever is greater. Weekly work schedules shall be posted one week in advance. Any employee required to work on his scheduled day off shall be paid at the one and a half times the straight time hourly rate, unless the employee takes off another day during such a work week for reasons other than the request of the Employer, or unless a change in work schedule results from a promotion or change of shift assignment pursuant to the operation of Section 14 hereof. In this event, new days off shall be scheduled to meet the new assignment and no penalty shall result for working a scheduled day off under the former assignment while effecting such a change. 
Employees called to work, or scheduled and reporting for work, or working four (4) hours or less in any day shall be offered a minimum of four (4) hours of work, and all employees working more than four (4) hours shall be offered eight (8) hours of work.

Any delays in daily operations caused by circumstances beyond the control of the Employer, such as failure of power or break-down of plant machinery or equipment, shall not require the payment of overtime, except to employees who may be continued at work during such delay interval.

"Holidays. (a) The following holidays will be recognized for eligible employees as hereinafter defined: New Year's Day, Memorial Day, Fourth of July, Labor Day, Thanksgiving Day, Christmas Day.

(b) Every employee is eligible for holiday benefits who has been on the Employer's payroll for thirty (30) days or more immediately prior to the holiday, and who works on his regularly scheduled work day next before and next after the holiday unless absence is with the Employer's consent.

(c) If a holiday falls on an eligible employee's regularly scheduled work day and he performs no work he shall receive holiday pay in an amount equal to eight times his regular straight time hourly rate of pay.

(d) If a holiday falls on an eligible employee's regularly scheduled work day and he works on the holiday he will receive holiday pay as provided in Section 5 (c) plus straight time pay for the first eight hours worked. Two times straight time pay will be paid for all hours worked over eight.

(e) If a holiday falls on an eligible employee's regularly scheduled day off and he works on the holiday he will receive two times straight time pay for all hours worked.

(f) Neither normal plant operation nor work schedules may be changed for the sole purpose of avoiding the operation of this section.

(g) It is mutually understood that regular part time employees working three or less days a week shall not be entitled to pay for holidays not worked.

"Vacations. Any employee who has been on the pay roll of the Employer for twelve (12) months or more within the preceding fourteen (14) months, shall receive one (1) week's vacation at his or her regular weekly rate of pay. All employees who have been in the employ of the Employer for two (2) years shall receive two (2) weeks' vacation at his or her regular weekly rate of pay. All employees who have been in the employ of the Employer for fifteen (15) years or more shall receive three (3) weeks' vacation at his or her regular weekly rate of pay. Any employee who has been employed at least twelve (12) months of straight time hours within the preceding fourteen (14) months and whose employment is termi- 
nated for any reason other than theft, drinking intoxicating liquor or intoxication on the job is entitled to pro rated vacation pay. Any employee who has been employed at least six (6) months of straight time hours within the preceding twelve (12) months, and who is laid off through no fault of his own, shall, upon being reemployed by the same company in the following year, be entitled to a pro rated vacation based upon his service in the preceding year.

Vacations are to be given normally between May 1st and October 1st, unless seniority or plant operation will be unusually affected; provided, however, other vacation periods may be mutually agreed to by both parties. Vacation allowances shall be computed on the basis of the employee's straight time hourly rate during the week immediately preceding the commencement of the vacation, plus any night work pay earned during such week. Where night work is regularly rotated, the night work pay shall be pro rated for this purpose. Employees entitled to vacation pay shall, upon their request, receive it at commencement of their vacation period.

"Night Work Pay. Any employee working between 6:00 p.m. and 6:00 a.m. shall receive ten cents per hour premium above the regular hourly rates.

"Welfare Plan. The Employer shall pay the sum of seven (\$7.00) dollars per month for each eligible employee to a trustee fund for the sole purpose of providing a hospital, medical and group life insurance under a plan to be executed."

One additional category of wage and salary expense is that of Social Security payments. The rate in 1953 was $1 \frac{1}{2}$ per cent of the salary or wages paid to an individual up to a maximum amount of $\$ 3,600$.

\section{Utility Rate Schedules}

Most of the California evaporated milk plants purchase gas and electricity from the Pacific Gas and Electric Company. The rates charged are subject to the approval of the California Public Utilities Commission. The following data are extracted from Schedule A-13 and Schedule G-50-A. The first of these contains electrical rates, the second gas rates.

Certain technical definitions are needed in order to understand and use the electrical rate schedule.

"(a) Maximum Demand: The maximum demand in any month will be the maximum average power taken during any 15 minute interval in the month, provided, however, that whenever such monthly maximum demand has exceeded $400 \mathrm{kw}$. for three consecutive months and thereafter until it has fallen below $300 \mathrm{kw}$. for 12 consecutive months, a 30-minute interval will be used; provided further, that in cases where the use of energy is intermittent or subject to violent fluctuations, a 5 -minute interval may be used....

"(b) Billing Demand: The billing demand to be used in computing charges under the ... schedule [below] will be the mean of the 
actual maximum demand as determined under (a) for the current month and the highest such demand occurring in the year ending with the current month."

The schedule of rates is as follows:

\section{Energy Charge:}

First $6,000 \mathrm{kwh}$ or less per month . . . . . . . . \$150.00

For all excess over $6,000 \mathrm{kwh}$ per month

First $50 \mathrm{kwh}$ per $\mathrm{kw}$ of billing demand..... 2.10 $\phi / \mathrm{kwh}$

Next $150 \mathrm{kwh}$ per kw of billing demand

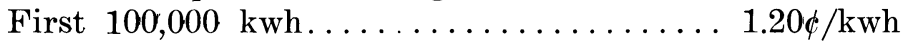

Balance .................... $0.85 \phi / \mathrm{kwh}$

Next $100 \mathrm{kwh}$ per $\mathrm{kw}$ of billing demand....... $0.85 \phi / \mathrm{kwh}$

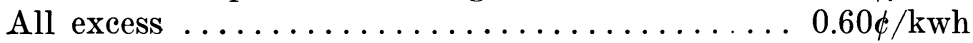

Minimum Charge, per month:

$\$ 150.00$ but not less than $90 \phi / \mathrm{kw}$ of billing demand.

To illustrate the use of this rate schedule, suppose that the billing demand as defined above is $300 \mathrm{kw}$. Using this figure, the rate schedule above can be converted to an effective rate schedule. The first class interval in excess of $6,000 \mathrm{kwh}$ per month is designated as $50 \mathrm{kwh}$ per $\mathrm{kw}$ of billing demand. Since the billing demand is $300 \mathrm{kw}$ the effective class interval is ( $50 \mathrm{kwh} / \mathrm{kw}$ ) $(300 \mathrm{kw})=15,000 \mathrm{kwh}$. The next class interval is $(150 \mathrm{kwh} / \mathrm{kw})(300 \mathrm{kw})=$ $45,000 \mathrm{kwh}$. The final class interval is $30,000 \mathrm{kwh}$. Thus, for a plant having a billing demand of $300 \mathrm{kw}$, the following rate schedule would be in effect.

\section{Energy Charge:}

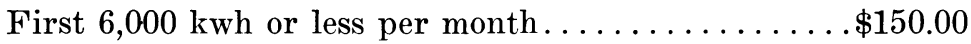

For all excess over $6,000 \mathrm{kwh}$ per month:

First 15,000 kwh................ 2.10 $\phi / \mathrm{kwh}$

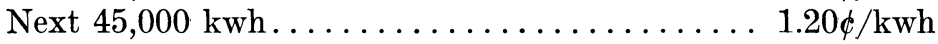

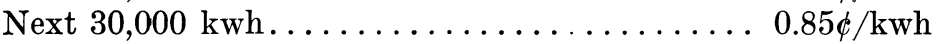

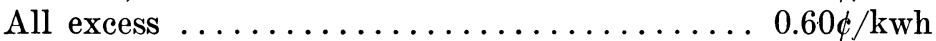

Minimum charge, per month:

$(\$ 0.90 / \mathrm{kw})(300 \mathrm{kw})=\$ 270.00$

Two rate schedules for gas were in effect during 1953. The one listed below was effective from March 23 through December 31, 1953, and is the one used in this study.

\section{Schedule G-50-A (1,100 Btu)}

Mcf $(1,000$ cubic feet $)$

cents/Mcf

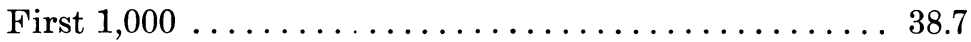

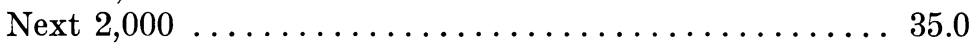

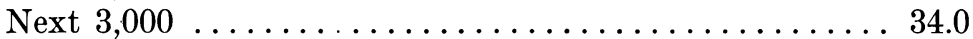

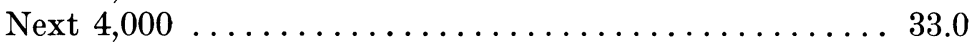

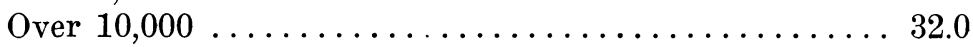




\section{Section III}

\section{TECHNOLOGY}

The primary purpose of this study is to estimate the relation between unit processing costs for evaporated milk and the capacity or scale of plant. If this objective were to be met fully, it would be necessary to consider alternative methods or techniques which could be used to perform each of the various functions necessary to produce evaporated milk. Such a complete analysis would require much larger research inputs than are currently available. Thus, the technology discussed below is, in general, typical of California plants. Certain minor modifications have been made. The equipment described is of modern design, which is frequently more efficient than similar equipment purchased at various times during the past twenty or more years. Reference has already been made to one simplification-no provision is made for separation of milk or pasteurization of cream since standardization is accomplished by the purchase of skim milk or cream.

Selecting equipment for a plant processing milk is simplified by the fact that many firms have designed and mass-produced efficient equipment to perform under specified conditions the various functions common to several milk products or peculiar to one. Many of the basic operations, such as transporting, testing, standardizing, heating, cooling, mixing, homogenizing, and evaporating, are present in all plants processing milk, affording the firm a certain flexibility in switching equipment from one product or plant to another or assuring a market for the equipment should liquidation become necessary.

The design of milk-processing equipment is generally the function of equipment producers. The price of equipment designed in this way and mass-produced in several models and with various capacities is generally below what it would be if every piece of equipment was specifically designed for each application and built on special order.

Equipment manufacturers or their agents have published extensive technical literature listing available models with their specifications. Although equipment companies may be inclined to exaggerate the general advantages of their equipment, their ratings of performance of particular pieces or types of equipment may be regarded as fairly reliable. Data from such publications and from textbooks of dairy engineering furnish the major part of the input-output information which economic theory usually assumes is furnished the economist by technical specialists.

Another characteristic of equipment used in evaporated milk plants, as well as in many other mechanized plants, is its suitability for operation at a fixed rate of output per unit of time. Variation in the quantity of output

${ }^{7}$ Much of the material presented in this chapter was obtained from a survey of the 11 California plants. Much was also obtained from technical literature supplied by equipment manufacturers. Finally, many of the technical details were found in Hunziker, Otto Frederick, "Condensed Milk and Milk Powder" (6th ed., published by the author, 1946, La Grange, Ill.) ; and Farrall, Arthur W., "Dairy Engineering" (2d ed.), New York: John Wiley and Sons, Inc., 1953. 
per month is achieved principally by altering the length of the operating day or the number of processing days per month. Perhaps the most important reason for this is the fact that milk is a complex substance. A slight variation in heat or agitation may cause a significant change in the characteristics of the finished product. A second reason is that the provision for alternative rates of output often involves an increase in investment cost which may not be justified by the increased flexibility. For example, a Waukesha Shiftspeed pump and electric motor designed to pump from 4,000 to 60,000 pounds of fluid per hour against 20 pounds head pressure costs approximately $\$ 1,968$. The same pump with the same electric motor in a constant speed combination costs approximately $\$ 1,106$. Several of the operations in evaporated milk plants are controlled by automatic equipment which can only be set to maintain approximately a constant pressure and/or temperature. Other items of equipment could operate at a slower rate than their maximum but would require just as much labor per hour with little or no saving in other inputs. Finally, as soon as some processes in a plant possess a fixed output rate, it becomes economical to operate others at corresponding rates to avoid intermediate storage operations.

Plant technologies may partially reflect the firm's uncertainty. As mentioned above, where it is possible with either no extra cost or only a slight extra cost, general-purpose equipment may be used instead of specialized equipment. Parallel processes utilizing smaller pieces of equipment may be substituted for a process using a single large piece of equipment in order that: (1) average variable and marginal costs be constant over a wide range of output, or (2) production not stop completely as a result of equipment breakdown. For example, it is typical for several steam boilers and refrigeration compressors to be provided rather than one large unit.

The scale of plant selected by a firm may also be influenced by uncertainty. In order to process a given flow of whole milk, a firm must choose between small plants operating a large number of hours per month and larger plants operating a smaller number of hours per month. If a small plant is selected, where the number of hours of plant operation is close to its upper limit, output can be increased only by the construction of new facilities.

For this reason and in order to minimize the problem of scheduling labor, each of the plants studied receives a sufficient quantity of whole milk per day during the month of maximum milk receipts to afford approximately eight hours of operation to each of the processes directly concerned with product flow.

\section{Product Flow}

The production of evaporated milk requires an integrated temporal sequence of elementary processes in each of which the basic raw material changes in location or form (fig. 1). For the purposes of this analysis, the sequence begins with the arrival at the plant of a truck loaded with 10-gallon cans containing whole milk and ends when cases of evaporated milk are loaded into trucks or railroad cars for distribution to the ultimate consumer. This long sequence of processes is typically split into three subsequences, here- 


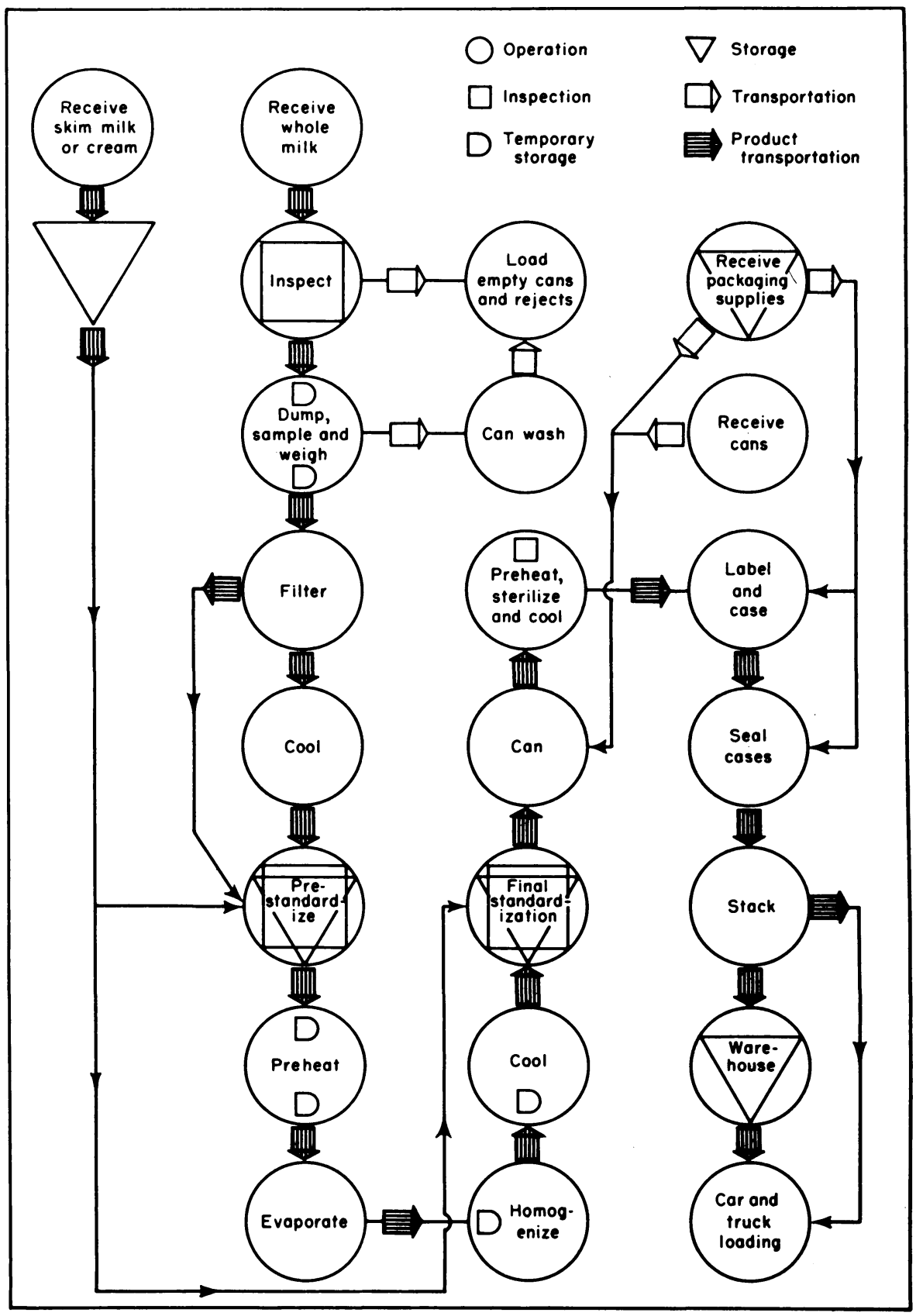

Fig. 1. Process flow chart for evaporated milk plants. 


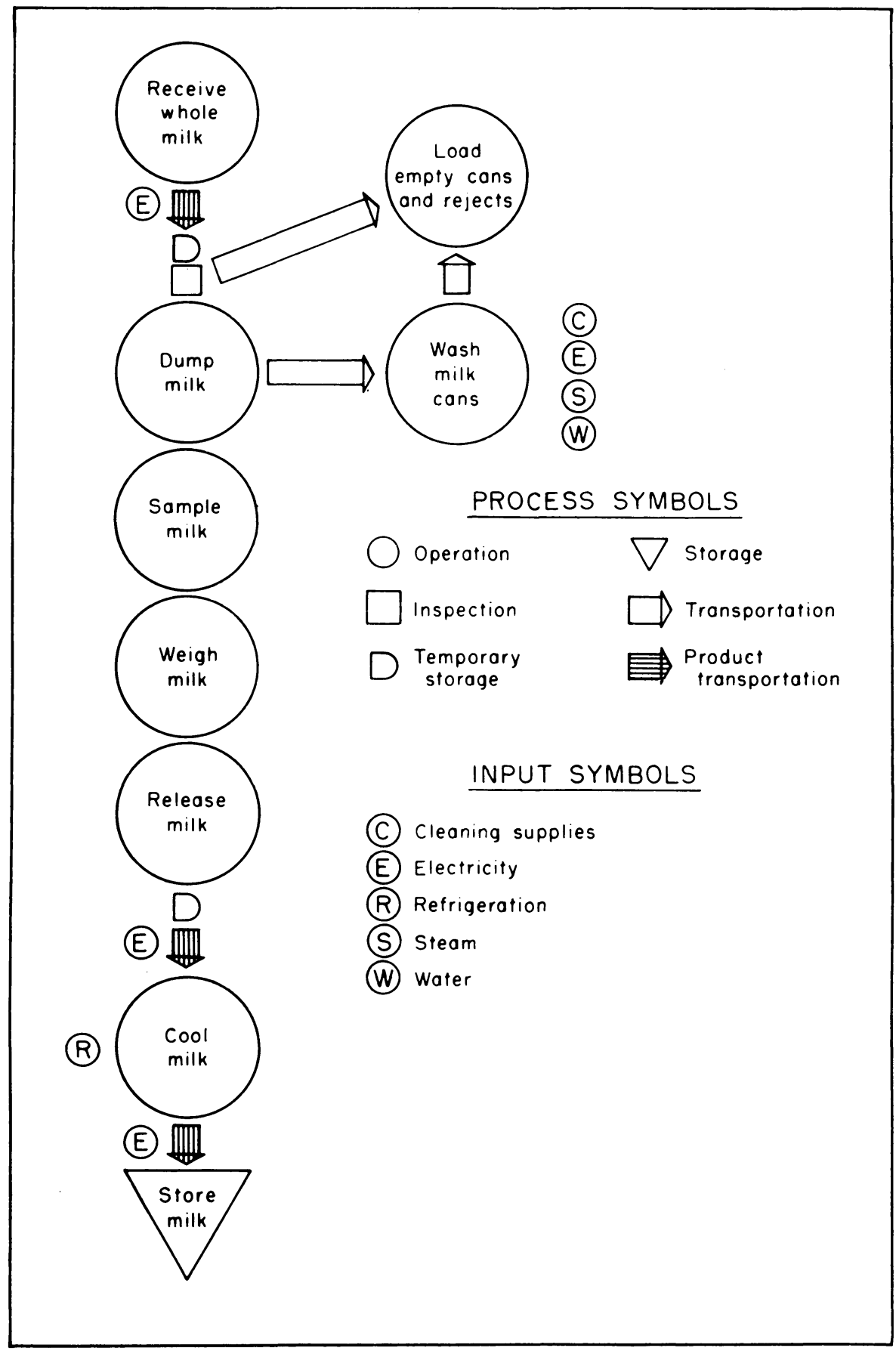

Fig. 2. Process flow chart for receiving stage. 
after called stages, each followed by a major storage operation, with the final process being the transfer of cases of evaporated milk from the warehouse to the trucks or railroad cars. The three stages are receiving, evaporating, and canning. Within each of these three stages, equipment is selected and operated so that the product output rate of the preceding elementary process is approximately or exactly the same as the product input rate of the following elementary process.

\section{Receiving Stage (Fig. 2)}

The truck driver lifts the 10-gallon cans from his truck and places them on a powered chain conveyor which carries them into the receiving room to an automatic can stop. Here the milk is inspected and, if satisfactory, dumped into a weighing tank which is suspended from a balance scale. Milk with a bad odor or bad appearance is returned to the dairy producer. The lids and empty cans are placed in a continuously operating automatic can washer where they are cleaned, sterilized, and dried. Then by another chain conveyor they are delivered to a location where they can be reloaded on trucks.

When all the milk from a single dairy producer is in the weighing tank or when the tank capacity is fully utilized, the weigher-sampler records the weight, dips a small sample for testing fat content, places it in a sample bottle, and releases a large valve which allows the milk to flow quickly into a receiving vat capable of holding from one and one half to two times as much milk as the weighing tank.

Stored in racks, the sample bottles are kept in a refrigerator when not in use. Daily samples are accumulated in the same bottle for several days and eventually tested in the plant laboratory to determine the average percentage of milk fat contained in the shipments from each producer.

Milk is pumped continuously from the receiving vat through a cloth filter to storage tanks if it is to be processed shortly or to a cabinet cooler if it is to be stored for some time prior to its utilization. If the plant is receiving twice per day, the usual arrangement is that the milk received during the evening of one day and the morning of the following day is processed during the second day. It is necessary to cool the milk received during the evening to about $40^{\circ} \mathrm{F}$ for overnight storage while the morning milk is not cooled. Some deviation from this procedure is necessary during the season of low milk supply since on some days milk is received but no processing takes place.

Cabinet coolers operate by directing the flow of milk in a thin film over a vertical stainless steel surface covering a collection of tubes containing ammonia. The heat is transferred from the milk through the stainless steel to the ammonia.

A major storage operation follows the receiving stage. Storage tanks are insulated with corkboard so that milk ean be stored for 24 hours or longer at $40^{\circ} \mathrm{F}$ with only an insignificant rise in temperature. Several tanks are needed so that the processing activities can be properly scheduled. ${ }^{8}$ For example, at a particular time, one tank could be used to receive milk pumped from the cooler, one tank could be used to store milk while it is being stand-

\footnotetext{
${ }^{8}$ See figures 12 and 13 , pp. 678 and 679.
} 
ardized, while milk could be pumped from a third tank to the preheater and evaporator.

According to a study made on labor utilization in milk receiving rooms, a one-man crew can dump milk, record weights, and take samples while handling from 14,000 to 17,500 pounds of milk per hour of operating time. A two-man crew under the same conditions can handle from 26,500 to 34,000 pounds of milk per operating hour. Larger crews achieve only a negligible increase in handling capacity.

\section{Evaporating Stage (Fig. 3)}

While in the holding tanks, the whole milk is standardized to the proper ratio of SNF to F by adding either skim milk or cream. Since the evaporated milk is homogenized immediately after passing from the evaporator, any fat present in the final product should also be present prior to evaporation.

After the milk is standardized, it is pumped into a holding tank through a heat exchanger utilizing milk vapor from the evaporator as the heating medium. From the holding tank or hot well, it is recirculated through another heat exchanger using steam as the heating medium until the temperature of the milk is approximately $212^{\circ} \mathrm{F}$, at which time it is introduced into the evaporator. The flows are adjusted so that the milk is held at approximately $212^{\circ} \mathrm{F}$ for 10 to 25 minutes.

This forewarming increases the output rate of the evaporator since the milk is at the boiling point prior to its introduction into the evaporator. It makes the finished product more stable to heat so that it can be safely exposed to the $240^{\circ} \mathrm{F}$ temperature used in the sterilization process. It also affects the viscosity of the finished product, an increase in the forewarming temperature and time of exposure being associated with a decrease in viscosity. The choice of forewarming temperature and holding time depends on their effects on the quality of finished product and so may vary from one plant to another. In the same plant, forewarming temperature and holding time may be varied from time to time to match the seasonal characteristics of the milk received.

All but two of the evaporators used in California evaporated milk plants are double-effect, vacuum-type evaporators designed to process milk continuously. "Double effect" means that a sequence of two evaporators is used, the first employing steam as the heating medium and operating with a vacuum corresponding to a boiling point for milk at approximately $170^{\circ} \mathrm{F}$. The milk vapor from the first evaporator is used as the heating medium of the second evaporator which operates at a vacuum corresponding to a boiling point for milk at approximately $140^{\circ} \mathrm{F}$.

Evaporated milk is withdrawn continuously from the evaporator at a rate which depends upon the capacity of the evaporator and the quantity of water to be removed per 1,000 pounds of whole milk. The operator observes a hydrometer floating in the finished product and adjusts the outflow to achieve the desired density. It is typical to overcondense slightly so that,

\footnotetext{
${ }^{\circ}$ French, Charles E., and G. B. Wood "Labor Utilization in Milk Receiving Rooms of Indiana Milk Plants." Purdue (Lafayette, Indiana) Agr. Exp. Sta. Bul. 576:34-35. 1952.
} 


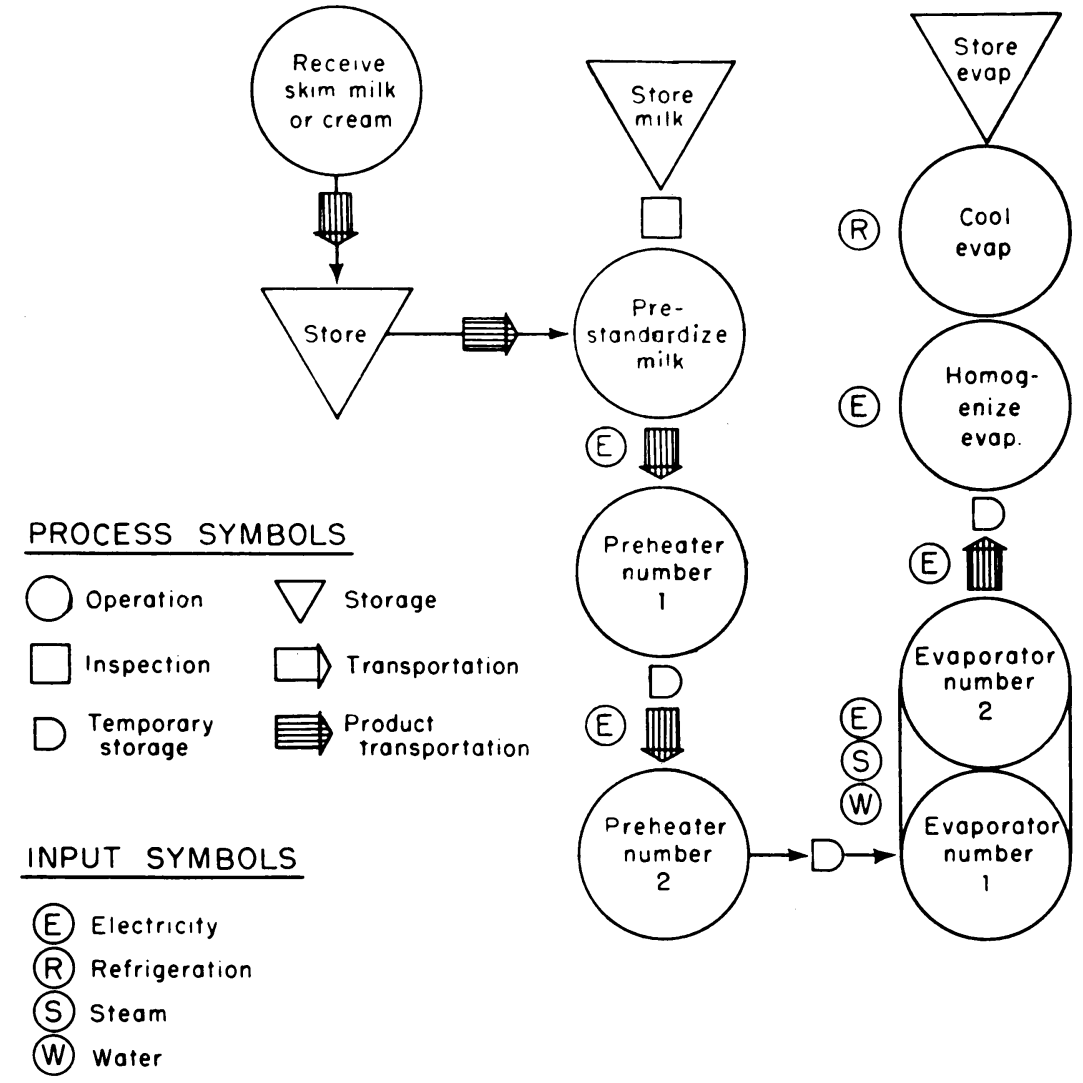

Fig. 3. Process flow chart for evaporating stage.

providing the proper ratio of $\mathrm{F}$ to $\mathrm{SNF}$ was achieved when the milk was prestandardized, final standardization is accomplished by adding a small amount of water.

Immediately after passing from the evaporator into a small surge tank, the evaporated milk is pumped through a homogenizer, a device which forces the milk through fine orifices at a pressure of about 2,500 pounds per square inch. This process breaks up the fat globules into particles so small that they will remain indefinitely in suspension.

After the evaporated milk is homogenized, it flows over a cabinet cooler whose upper tubes contain water and lower tubes contain ammonia. Cooling to about $40^{\circ} \mathrm{F}$ is necessary both to insure minimum bacterial growth prior to canning and sterilizing and to prevent foaming if the milk is to be canned immediately. If the milk foams during the canning process, the inlets of the cans become wet and prevent effective soldering. 


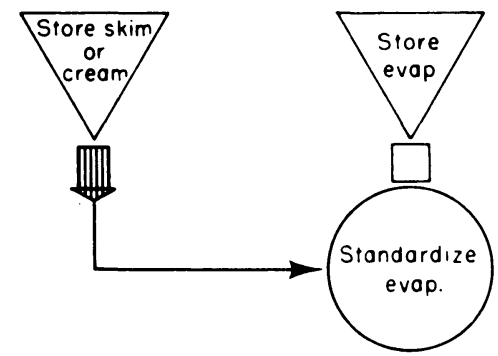

(E)
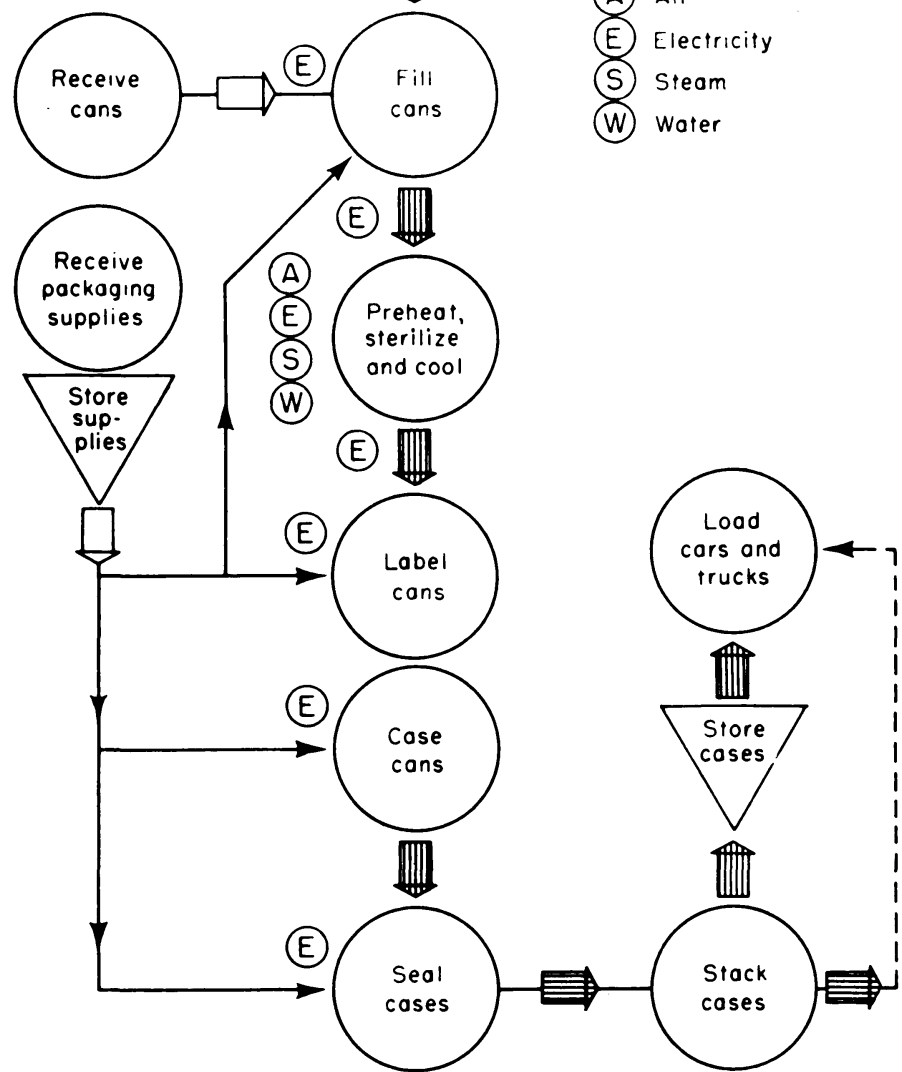

Fig. 4. Process flow chart for canning stage.
PROCESS SYMBOLS

Oiperation $\nabla$ storage

$\square$ Irspection $\square$ Tronsportation

$D \begin{gathered}\text { Temporary } \\ \text { storage }\end{gathered}$

INPUT SYMBOLS

(A) Air

(E) Electricity

(S) Steam

(W) water 
From the cooler, the evaporated milk flows to insulated storage tanks where final standardization takes place. Here, too, several tanks are required so that one tank receives evaporated milk, a second contains milk being standardized, and a third contains standardized milk flowing to the can fillers. ${ }^{10}$

A two-man crew is typical for the evaporating stage. One man operates the evaporator while the second assists him in controlling the flow of whole milk from and the flow of evaporated milk to the various storage tanks. The helper also washes tanks and pipe lines.

\section{Canning Stage (Fig. 4)}

After final standardization, the evaporated milk is pumped from the storage tanks to a pressure tank at least $\mathbf{1 4}$ feet above the can fillers, affording sufficient static pressure to actuate the free-floating pistons of the can fllers. Almost all evaporated milk plants in California employ the Dickerson automatic vent-hole filler and sealer, models of which are available for filling the two standard cans containing 141/2 or 6 ounces, respectively. Two sizes are available for 141/2-ounce cans-one having 60 filling units and the other 48. Although rates listed by the manufacturer are 125 to $155 \mathrm{cpm}$ (cans per minute) for the larger filler and 100 to $115 \mathrm{cpm}$ for the smaller one, these rates have been exceeded in practice. Providing the sterilizer capacity is sufficiently large, rates in excess of $165 \mathrm{cpm}$ and $140 \mathrm{cpm}$ have been achieved. ${ }^{11}$ The same machine, after the cans are filled, seals the small vent in the top of the can with a drop of solder. Auxiliary equipment is used to reject automatically cans which are light weight or are incompletely sealed or which contain solder pellets. Improperly sealed cans are hand soldered. Other rejected cans are opened and the milk retained for further use.

A continuous flow of empty cans is required to allow continuous operation of the can fillers. Several of the evaporated milk plants, producing cans in an adjacent room or building, are able to feed cans at the appropriate rate directly from the production line, but the majority of California plants obtain cans from other evaporated milk plants or can factories. Although a small stock of eans is usually stored at the plant, the tendency is to purchase them in carload lots and feed them directly from the railroad cars through can rolls and elevators to the filling machines.

The filled cans are fed through can rolls to one or more continuous automatic preheater-sterilizer-coolers set to operate at a slightly higher rate than the can-filler combination. All California plants employ AndersonBarngrover continuous sterilizers. Although other sizes have been furnished in the past, the company is standardizing current production on two capacities for the 141/2-ounce can, one containing 1,974 cans in the sterilizer and the other, 2,585. For a given capacity, the rate in cans per minute is determined by the length of the sterilization cycle. At one time ranging from 15 to 18 minutes, current sterilizing times now range from about 12 to 15 minutes and are inversely related to the sterilization temperature. In order

${ }^{10}$ See figures 12 and 13, pp. 678 and 679.

11 This statement is based on data obtained from a representative of Food Machinery and Chemical Corporation, producer of the Anderson-Barngrover continuous sterilizer. 
to prevent buckling of the cans as their contents are heated to about $240^{\circ} \mathrm{F}$, the retorts through which the cans pass are kept at higher than atmospheric pressure by compressed air. The heating medium is steam, while the cooling medium is water.

The cans, now containing sterilized evaporated milk, are transported on can rolls through an automatic labeling machine to a casing machine. Here, the cans are separated into four rolls so that it is possible to insert 24 or 48 cans into a cardboard case with each operation of a control lever. When the case is full, it is lowered to a moving belt which carries it through an automatic top and bottom case gluer and sealer. The sealed cases are then transferred on rolls to a position where they are stacked by hand on pallets. As the pallets are filled, they are transferred by fork-lift truck to the warehouse where they are stored prior to shipment.

Each can filler requires one operator. His duties include: (1) making minor adjustments on the equipment to keep it operating effectively ; (2) hand-soldering cans not properly sealed; and (3) providing rolls of solder as needed. Men are required to transfer cans from railroad cars to can rolls. The rate used here as standard is 100 cans per minute per person. One man can operate one or two sterilizers. One man operates a labeler and caser and one or more men stack cases. The rate used as a standard for stacking cases is nine cases per minute per man. One man operates the fork-lift truck.

\section{Cleaning Stage}

Where time permits, much of the cleaning and sterilization of equipment is performed by the equipment operators. In almost all plants, however, there is need for a separate crew to disassemble, clean, and sterilize some of the equipment of the evaporating and canning stages.

\section{Utility Stage}

In addition to the direct processing stages, evaporated milk plants are equipped to produce steam, refrigeration, and water. Most California plants purchase rather than produce electricity.

All California plants produce steam from a multiple installation of boilers, allowing for the shutdown of at least one boiler at a time for repair and maintenance. All are equipped for and burn natural gas except for short periods during the winter when they may be cut off by excessive demand for gas for residential heating. Oil is used during these periods. After the steam is produced and distributed at a pressure of 100 psi (pounds per square inch), it is used to heat cleaning water, to heat and evaporate the milk, to sterilize 10-gallon cans and other equipment, and to sterilize the evaporated milk after it is canned. In most cases steam is available at all times since a large amount of cleaning and sterilizing of equipment is scheduled while other processes are not in operation.

A refrigeration system is required to provide the necessary cooling of raw milk for storage and evaporated milk either for storage or as a preliminary to can filling. A multiple installation of compressors is used. Although other refrigerants may be employed, by far the most common is ammonia. Evapora- 
tive condensers are used to cool the ammonia after it leaves the compressors. Typical operating conditions are: (1) cooling water at $70^{\circ} \mathrm{F}$; (2) back pressure at $40 \mathrm{psi}$; and (3) head pressure at $165 \mathrm{psi}$.

California plants provide water from their own wells. Typical operating conditions are: (1) a total pumping head of approximately 200 feet, including an operating pressure aboveground of approximately 100 feet, and (2) a water temperature of approximately $70^{\circ} \mathrm{F}$.

Although most of the utility equipment is automatic or semiautomatic, almost all plants maintain a continuous supervision with three one-man shifts per day.

\section{Laboratory Stage}

Laboratory work consists of two phases: (1) testing the fat content of milk receipts for payment purposes, and (2) testing milk for the purpose of controlling the quality of raw and finished product. Accurate tests are made of composition, bacterial count, sediment, viscosity, stabilization requirements, et cetera.

\section{Management Stage}

The primary functions of the general office are: (1) keeping general accounting records; (2) handling personnel and payroll matters; (3) keeping records of and making payments for milk receipts ; and (4) keeping other records of management and control. Since most evaporated milk plants are owned by firms having their main offices elsewhere, there is a possibility of rather wide variation in the quantity of this work performed at the plant as compared with that performed elsewhere. Variation is also possible in the amount of additional work required for reports to the parent firm.

The functions of shipping product and receiving supplies are almost selfexplanatory. The receiving function includes keeping an inventory of, and handling supplies which are used directly, such as cans, cartons, labels, paste, and solder as well as such general supplies as brushes, brooms, and cleaning agents. A further requirement is that of scheduling receipts of supplies to avoid production delays. The shipping function is primarily one of transferring, on order, cases of evaporated milk from the plant warehouse to trucks or railroad cars and of keeping inventory control over the warehouse stock.

Perhaps the most important management activity is scheduling the activity of each of the stages. Given the daily flow of milk to the plant, management's primary opportunity to reduce costs is to develop work schedules which, subject to the conditions of the labor agreement, will result in a minimum labor cost.

\section{Section IV}

\section{SPECIFICATION OF THE ECONOMIC MODEL}

As stated before, the primary objective of this study is to measure the relationship between scale or capacity of plant and unit cost of processing evaporated milk under previously specified institutional and operating conditions. 
A secondary objective is to measure, for each of several specific plants, the relationship between annual output and unit processing costs. Prior to measurement, it is necessary to consider all cost categories that enter into unit processing cost and to define the conceptual framework to which they apply. ${ }^{12}$

\section{Choice of Accounting Period}

The choice of accounting period depends on the analytical objective. If the primary objective were to measure how unit processing cost varies with alternative seasonal patterns of milk receipts, it would be necessary to estimate costs on a monthly or weekly basis. For the purposes of this study, the average seasonal pattern of milk receipts is assumed to be fixed. Consequently, an annual accounting period is used and annual average unit cost estimated.

\section{Cost Categories}

\section{Durable Asset Costs}

Certain costs are associated with the ownership of durable assets. The first of these to consider is the original total cost of acquisition. Total investment cost is further classified into costs of site purchase and development, equipment purchase and installation, building construction, and inventory provision. (Strictly speaking, working capital in the form of inventories of raw material, supplies, goods in process, and finished goods is not a durable asset. It does, however, continue to exist over time and constitutes, on the average, a definite amount of investment.) These costs do not enter directly into unit processing cost but give rise to certain annual costs.

Equipment, buildings, and site improvements are durable assets which depreciate in value due to: (1) physical wear and tear while in use; (2) deterioration, such as decay, not caused by use but associated with the passage of time; and (3) obsolescence. The annual reduction in value is a cost which is charged against annual output. While there is considerable disagreement over the correct way to allocate the original cost of a depreciable asset to specific accounting periods, by far the most common method is to: (1) estimate the normal useful life of the asset; (2) estimate salvage value at the end of its useful life ; and (3) allocate the difference between original installed cost and salvage value uniformly to each accounting period during the useful life of the asset. For a specific plant, the application of this method results in a constant amount of depreciation cost to be charged against annual output.

Other recurrent costs are associated with the ownership of durable assets. During each year, interest cost applies to the undepreciated balance of the initial investment. Insurance premiums and property taxes are recurrent costs which are related to estimated current value of assets. Finally, repair

\footnotetext{
${ }^{12}$ For a more general development of cost theory and measurement see: Committee on Price Determination, "Cost Behavior and Price Policy." New York: National Bureau of Economic Research. 1943; Bressler, R. G., Jr., "Research Determination of Economies of Scale," in Journal of Farm Economics 27:526-539, August, 1945; and French, B. C., L. L. Sammet, and R. G. Bressler, "Economic Efficiency in Plant Operations with Special Reference to the Marketing of California Pears," in Hilgardia 24(19) :543-721. 1956.
} 
and maintenance cost must be included. Conceptually, repair and maintenance cost can be split into two categories: (1) a constant annual cost, and (2) a variable annual cost which depends upon the number of hours of plant operation. Practically, it is difficult to distinguish sharply between the various categories of depreciation and repair and maintenance costs. Since there is significant interaction between repair and maintenance expenditures and normal useful life, they should be estimated jointly.

Even though several of these costs vary from one year to another, principally in response to increasing plant age and diminishing undepreciated investment, for the purpose of estimating unit processing cost they are aggregated for the useful life of the plant and allocated uniformly to each year.

\section{Fixed Labor and Management Costs}

Within a normal range of alternative annual output rates, certain annual labor and management costs do not vary. Plant management typically consists of a general plant manager, an office superintendent, and a plant superintendent, all of whom are usually paid an annual salary.

Various processes within each plant require water, steam, and refrigeration to be available throughout the entire day. While much of the equipment is automatic or semiautomatic, most plants maintain continuous supervision of utility equipment.

One of the primary functions of laboratory personnel is to test milk samples for fat content in order to determine the proper payment to milk producers. The number of personnel required is more closely related to the number of milk producers than to the volume of milk received and processed. Similarly, a major part of the office function is not closely related to the volume of milk received and processed. Consequently, within the range of variation in annual output considered here, each plant is assigned a fixed number of laboratory and office personnel.

\section{Fixed Supply Costs}

Just as the annual labor costs for office and laboratory are approximately constant within a range of alternative annual output rates, so are the supply costs for these two functions.

\section{Variable Costs}

All other processing costs vary with alternative annual output rates. Variable inputs purchased by evaporated milk plants are labor, electricity, gas, cleaning supplies, packaging supplies, and the services of certain equipment.

Almost all equipment in evaporated milk plants operates at constant time rates of inputs and corresponding constant time rates of output. Consequently, there tends to be a constant ratio between the quantities of inputs and the quantity of output. Variation in annual output is achieved principally by varying the number of days of plant operation.

There are minor variations in input-output ratios. These are due to: (1) seasonal variation in organization of the receiving crew in response to seasonal variation in daily milk receipts; (2) seasonal variation in the rate of 
refrigeration per thousand pounds of milk received in response to seasonal variation in temperature and processing schedules; and (3) seasonal variation in the output rate of the evaporator in response to seasonal variation in milk composition. One further variation is due to the indivisibility of labor inputs. The basic labor unit is the eight-hour day. Average daily receipts must fall significantly below the amount which can be processed during eight hours before it becomes practicable to store milk receipts for more than 24 hours. Thus, a step function is needed to express exactly the relationship between annual milk receipts and man-hours of direct processing labor.

Increases in daily receipts above the amount that can be processed in eight hours causes a proportional increase in the quantity of direct processing labor, but variable labor costs increase more rapidly through overtime payments.

Not only do input-output ratios vary. Cost rates for gas and electricity depend upon the quantities used per month, larger quantities being associated with lower rates.

\section{Cost Functions}

In order to develop in broad outline the conceptual framework to which the various cost categories belong, the relatively minor variations in inputoutput ratios and cost rates will be ignored for the time being.

Only a limited range of alternative annual outputs will be considered, a range within which total variable costs are approximately proportional to annual output. The upper limit of this range is the output per year which, given the seasonal variation in milk receipts and the eight-hour processing capacity of the particular plant, results in daily plant operation at eight hours per day during the period of maximum daily milk receipts.

The lower limit cannot be defined so precisely. For total variable costs to be directly proportional to annual output, plants must be able to vary the number of processing days in direct proportion to annual output, and fixed costs must remain fixed. Plants are limited in the number of successive days during which no direct processing occurs. This may be due to a limitation in whole milk storage capacity or to potential milk spoilage if the milk is stored too long. In addition, certain labor categories such as laboratory and office personnel, assumed above to be fixed, would probably not be fixed if annual output were far below annual capacity.

\section{Cost Function for a Specific Plant-Short Run Cost Function}

Total annual processing cost for a specific plant is found by adding total annual fixed cost and total annual variable cost. Suppose that these costs are available for annual output corresponding to the upper limit defined above. Total variable cost is then divided by annual output to obtain average variable cost per case. Total annual processing cost for alternative outputs within the range of definition would then be the sum of annual fixed cost and the product of average variable cost per case and annual output. 
Rather than use hypothetical figures to illustrate this concept, the estimated short run cost function for Plant I is used. (See Section VIII.) For capacity output of 468,600 cases of evaporated milk, total fixed cost is estimated to be $\$ 115,000$ and total variable cost is estimated to be $\$ 111,000 .^{13}$ Average variable cost per case is $\$ 0.2369$. Thus the cost-volume relationship for Plant $I$ is summarized in the following equation:

$$
\mathrm{TC}_{\mathrm{I}}=115,000+0.2369 \mathrm{Q}_{\mathrm{I}}
$$

where $\mathrm{TC}_{\mathrm{I}}$ represents total annual processing cost measured in dollars and $\mathrm{Q}_{\mathrm{I}}$ represents annual output measured in cases of evaporated milk. This equation is defined only for outputs less than 468,600 cases. For ease of interpretation, this equation is converted to an average cost equation by dividing both sides by $Q_{\text {I }}$.

$$
\mathrm{AC}_{\mathrm{I}}=\frac{115,000}{\mathrm{Q}_{\mathrm{I}}}+0.2369
$$

$\mathrm{AC}_{\mathrm{I}}$ is average processing cost per case for Plant I. Processing cost for an annual output of 300,000 cases is $\$ 0.62$ per case. For capacity output of 468,600 cases it is $\$ 0.48$ per ease. This average short run processing cost function is illustrated in fig. 5 .

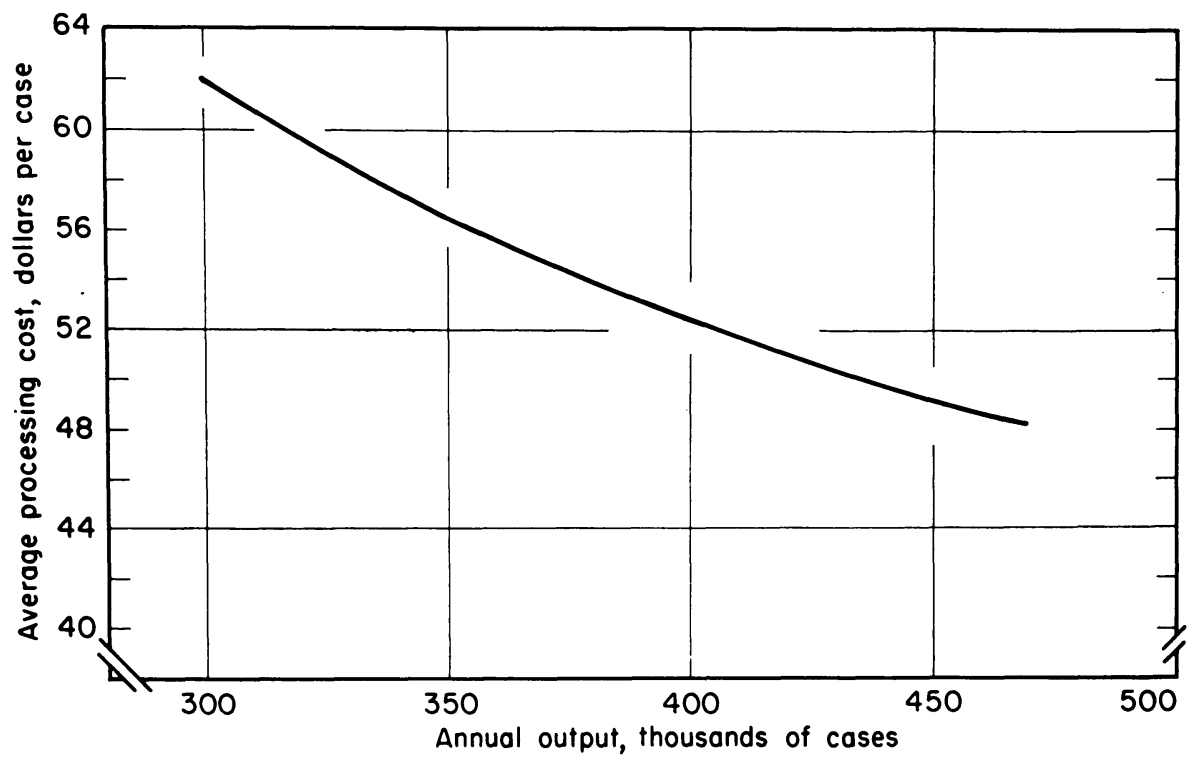

Fig. 5. Short run average processing cost function.

\section{Long Run or Planning Cost Function}

The long run or planning cost function is best defined operationally. For each of a large number of alternative annual output rates, a particular plant is selected which proeesses that annual quantity at minimum average cost per unit of output. The locus of minimum cost points for all alternative annual outputs forms the long run cost function. Each point on the function

\footnotetext{
${ }^{13}$ Packaging supply cost is excluded.
} 
may correspond to a different plant. On the other hand, if the number of possible plants is limited, the same plant may be the minimum cost plant for a range of alternative annual outputs. The long run cost function is of primary interest to a firm faced with the problem of selecting the particular size or scale of plant to construct, hence its alternative title, the planning cost function.

The long run cost function developed in subsequent sections is more limited in scope than the concept defined above. The two major limitations are:

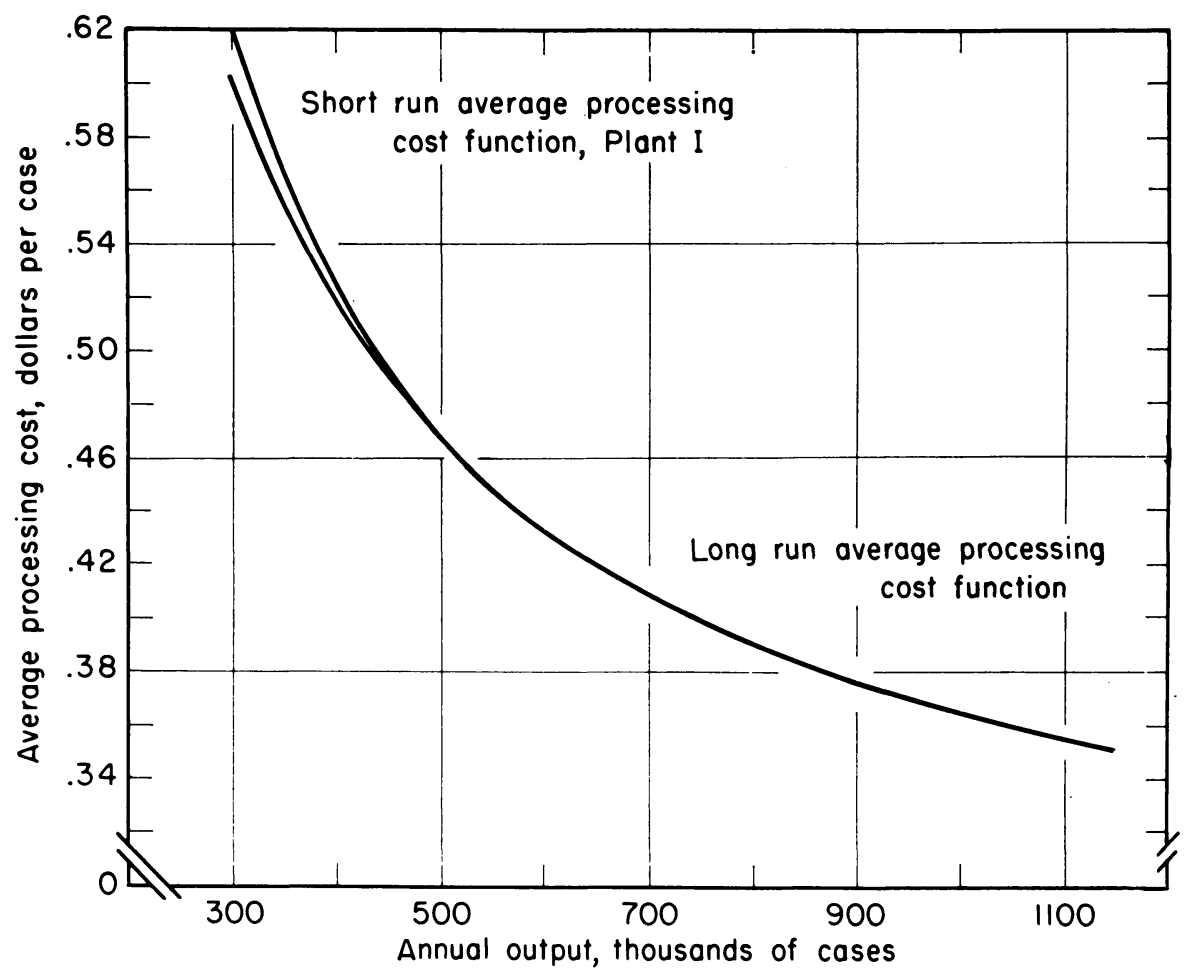

Fig. 6. Short run and long run average processing cost functions.

(1) the specification of stage and plant capacity or scale in terms of the amount of raw product that can be processed in eight hours, and (2) the specification that each plant employs approximately the same technology. Thus, for a particular annual output rate, lower average processing costs per unit of output than those estimated might be achieved by: (1) building a smaller plant and operating it for a longer period of time, or (2) by selecting an alternative technology.

The long run cost function is also illustrated by a particular equation derived in succeeding sections.

$$
\mathrm{TC}=102,200+0.2626 \mathrm{Q}
$$

where TC is annual processing cost measured in dollars; $Q$ is annual output in cases for a plant operating at capacity as here defined, and $Q$ is less than 
1,143,000 cases of evaporated milk. Each value for Q represents a different plant designed for that particular capacity. This function is also converted to an average cost function by dividing by $\mathrm{Q}$,

$$
\mathrm{AC}=\frac{102,200}{\mathrm{Q}}+0.2626
$$

Average processing costs for plants having annual capacities of 500,000 and $1,000,000$ cases are $\$ 0.47$ and $\$ 0.36$ per case.

The short and long run cost functions are closely related. Each point on the long run cost function represents the cost for a specific plant designed to process the corresponding output. Thus a specific short run function has as its common point with the long run function the cost at capacity output. An average cost of $\$ 0.48$ per case for capacity output of Plant I has already been derived from the short run function. This output, 468,600 cases, applied to the long run function also yields the same value, $\$ 0.48$ per case. Both functions are illustrated in figure 6. For output rates smaller than capacity, the costs for Plant I are higher than costs on the long run function for plants specifically designed for the smaller rates of output. For example, the average cost for Plant I for an annual output of 300,000 cases is $\$ 0.62$ per case. The long run average processing cost per case for the same annual output is $\$ 0.60$.

\section{Section V}

\section{PLANT SPECIFICATION AND ESTIMATION OF EQUIPMENT AND BUILDING COSTS}

\section{Plant Specification}

\section{Choice of Plant Capacities}

At least two procedures can be used to select plant capacities. One of these is to select arbitrarily a set of annual milk volumes which span the desired range. The second method is to select a set of plants in such a manner that the input-output rates of successive items of equipment mesh with one another. The second approach is used since it allows all the plants to be similar in their integration of the many necessary functions and yet be dissimilar in their eight-hour capacity for processing milk. Thus, differences in unit cost between plants can be more definitely associated with changes in scale.

Key elements in the choice of plant capacities are the can filler and sterilizer combinations. Only two sizes of each of these are available as standard equipment-can fillers handling 48 or 60 cans simultaneously and sterilizers handling 1,974 or 2,585 cans simultaneously. Sterilizer and can filler combinations are chosen so that the potential output rate for each sterilizer is approximately $5 \mathrm{cpm}$ greater than the anticipated input rate from the can fillers. Standard rates for the two can fillers are 130 and $160 \mathrm{cpm}$, respectively. The sterilizers can be set for a processing cycle of from 12 to 15 minutes, resulting in output ranges of 132 to $165 \mathrm{cpm}$ and 172 to 215 
cpm. The output of the larger can filler matches closely the upper limit of the small sterilizer. This combination is the one selected for Plant I, which has the smallest capacity of the plants to be studied. The effective output rate for this combination is $160 \mathrm{cpm}$. Other combinations extend the output range from 160 to $640 \mathrm{cpm}$. All but one of these combinations allow both the can fillers and sterilizers to operate at or near the upper limit of their capacity. Plant II, however, uses a sterilizer cycle of 14.6 minutes, which

TABLE 7

SELECTED CAN FILLER AND STERILIZER COMBINATIONS

\begin{tabular}{|c|c|c|c|c|c|}
\hline \multirow{2}{*}{ Plant } & \multirow{2}{*}{$\begin{array}{c}\text { Can filler } \\
\text { combinations }\end{array}$} & \multirow{2}{*}{$\begin{array}{l}\text { Sterilizer } \\
\text { combinations }\end{array}$} & \multicolumn{2}{|c|}{ Rates of operation } & \multirow{2}{*}{$\begin{array}{l}\text { Sterilizer } \\
\text { cycle }\end{array}$} \\
\hline & & & Can filler & Sterilizer & \\
\hline & cell & pocket & cpm & cpm & $\min$ \\
\hline I. $\ldots \ldots \ldots \ldots \ldots$ & $60(1)$ & $1,974(1)$ & 160 & 165 & 12.0 \\
\hline II $\ldots \ldots \ldots \ldots \ldots$ & $48(2)$ & $1,974(2)$ & 260 & 270 & $14.6^{*}$ \\
\hline III. . & $60(2)$ & $1,974(2)$ & 320 & 330 & 12.0 \\
\hline IV. & $48(3)$ & $2,585(2)$ & 390 & 400 & 12.9 \\
\hline V. & $60(3)$ & $1,974(3)$ & 480 & 495 & 12.0 \\
\hline VI. . & $60(4)$ & $1,974(4)$ & 640 & 660 & 12.0 \\
\hline
\end{tabular}

* This cycle is significantly longer than the others because the rate of output of a 48-cell can filler is less than the capacity rate of a 1,974-pocket sterilizer combination.

'TABLE 8

AVERAGE QUANTITY OF WHOLE MILK RECEIVED PER DAY DURING MAY, BY PLANTS

\begin{tabular}{|c|c|}
\hline Plant & $\begin{array}{l}\text { Average quantity } \\
\text { of whole milk } \\
\text { received per day } \\
\text { during May }\end{array}$ \\
\hline & $l b s$ \\
\hline I. & 146,000 \\
\hline II. & 237,000 \\
\hline III. & 292,000 \\
\hline IV. . & 356,000 \\
\hline V... & 438,000 \\
\hline VI $\ldots \ldots \ldots \ldots \ldots \ldots \ldots$ & 584,000 \\
\hline
\end{tabular}

is significantly slower than its potential of 12 minutes. Since rental payments on the sterilizer equipment are made on a per-case basis, it is less important that the sterilizer be operated at maximum capacity, providing a sufficient quantity is processed to cover the minimum annual charge. Table 7 lists the combinations chosen and the rates at which the components are operated.

Plant I, then, operating at $160 \mathrm{cpm}$ produces 1,600 cases of evaporated milk in eight hours. Using the conversion factor for milk received during May, 10.97 eases per 1,000 pounds of whole milk processed, ${ }^{14} 1,600$ cases of evaporated milk requires 145,850 pounds of whole milk. This figure is

\footnotetext{
${ }^{14}$ See Table 3.
} 
rounded to 146,000 . The application of this procedure to each of the plants results in the average daily receipts listed in Table 8.

\section{Receiving Stage}

The general procedure followed in this and subsequent sections is to describe in detail the selection of equipment and estimation of investment costs for Plant I and then to summarize the results obtained from similar analyses for the other five plants. Stage equipment lists for Plants II through VI are found in Appendix Tables 3 through 22.

In some cases, technical literature published by equipment companies is sufficiently detailed to allow a rational selection of equipment by the author. ${ }^{15}$ In other cases, representatives of these firms designated particular items of equipment to perform specified activities.

For Plant I, equipment must be selected which will enable the receiving crew to receive 146,000 pounds of whole milk per day or 73,000 pounds per shift. According to the specifications listed on page 624, this implies that Plant I receives milk from 292 producers and handles 1,123 ten-gallon cans per shift. If the eapacity of the weighing tank and scales is 500 pounds, the specifications further imply that the number of separate weighings per shift is 1.25 the number of producers or $365 .^{18}$

Whether receiving is a one-man or a two-man operation, only one man is used to dump the milk into the weighing tank. Standard time for this activity is 0.0918 minute per can, ${ }^{17}$ which is equivalent to a dumping rate of $10.9 \mathrm{cpm}$. Standard time for taking a milk sample from the weighing tank, recording the weight of milk, and releasing the milk into the receiving vat is 0.1882 minute when a one-man crew is used. ${ }^{18}$ Total receiving time per shift for a one-man crew for these two operations would then be: $(1,123$ cans) (0.0918 minute per can $)+(365$ weighings $)$ (0.1882 minute per weighing) $=172$ minutes. Adding 15 per cent to this for personal and fatigue time allowance, operating time would be 198 minutes or 3.3 hours, leaving the remainder of the eight-hour shift for setup, cleanup, and idle time while waiting for truck arrivals.

However, since the milk cannot be dumped faster than the cans are taken into the can washer, this rate could be achieved only with a 12-cpm washer even though the effective dumping rate is $6.5 \mathrm{cpm}$.

An 8-cpm washer would increase the unit dumping time from 0.0918 to

15 Such technical literature is supplied without charge by equipment manufacturers.

${ }^{16}$ (a) 146,00 lbs. of whole milk 500 lbs. per producer $=292$ producers

(b) $\frac{73,000 \mathrm{lbs} \text {. of whole milk per shift }}{65 \mathrm{lbs} \text {. per can }}=1,123$ cans per shift

(c) $(.85)$ ( 1 weighing per producer $)+(.10)$ ( 2 weighings per producer $)+$ (.05) ( 4 weighings per producer) $=1.25$ weighings per producer.

${ }^{17}$ French and Wood, op. cit., p. 53. Standard times represent reasonably efficient rates which can be achieved by most plants. These standards were estimated by work measurement procedures.

${ }^{18}$ Loc. cit. 
0.1250 minute per can and increase total receiving.time from 172 minutes to 209 minutes. Including a personal and fatigue allowance of 15 per cent, operating time would be 4.0 hours. This would still leave sufficient time for other activities and would require a smaller investment. Consequently, an 8-cpm can washer is selected for Plant I. Effective maximum rate of milk flow during working time would then be 21,000 pounds per hour ${ }^{19}$ or 349 pounds per minute.

Total conveyor length recommended for an 8 -cpm rate is 118 feet. ${ }^{20}$ This length provides adequate temporary storage for incoming full cans and outgoing empty cans. Other items selected are a 500-pound weighing tank and scale, a 1,000-pound receiving vat, power units, dump saddle, can stop for full and empty can conveyors, and a refrigerated case for holding at least 292 milk samples.

The next problem is that of selecting equipment to transfer the milk from the receiving vat through a filter and cabinet cooler to the storage tanks. A duplex filter capable of filtering approximately 21,000 pounds per hour per unit for up to two hours is selected. The milk is directed through one unit for two hours and then switched to the other for the remainder of the shift.

A pump is selected which is capable of forcing approximately 21,000 pounds of milk per hour through a 2 -inch sanitary pipe, through the filter to the top of a cabinet cooler. Friction head per 100 feet of 2 -inch sanitary pipe is approximately 5 feet. Each $90^{\circ}$ elbow is approximately equivalent in friction head to 8 feet of straight sanitary pipe. ${ }^{21}$ Milk must be pumped through the equivalent of 76 feet of pipe against the corresponding friction head of 4 feet. The maximum friction head of the filter is listed as approximately 30 feet. The static lift from the pump to the top of the cabinet cooler is approximately 4 feet, making a total operating pressure of 38 feet. A flow of 21,000 pounds per hour against 38 feet of head can be maintained by a $1 \frac{1}{2}$-hp centrifugal pump.

A cabinet cooler is selected to cool 21,000 pounds of milk per hour to $40^{\circ} \mathrm{F}$. The maximum temperature difference is $59^{\circ} \mathrm{F}$. This cooling range would require the removal of $116,500 \mathrm{Btu}$ per hour or 97 tons of refrigeration. ${ }^{22}$ Ammonia controls are selected to correspond to this maximum load.

The final major item required for the receiving stage is a pump to transfer the milk from the cooler to the storage tanks. The maximum resistance encountered here is the equivalent resistance of approximately 130 feet of straight 2-inch pipe or 6.5 feet of head, plus a static head from the bottom

1973,000 lbs. of milk

$\overline{(209 \text { minutes })(1 / 60 \text { hrs per minute })}=21,000 \mathrm{lbs}$. per hr.

(21,000 lbs.) (0.94 Btu per pound per degree Fahrenheit.) (59॰ F.) $=116,500 \mathrm{Btu}$

${ }^{21}$ Farrall, op. cit.

${ }^{22}$ The specific heat of milk is approximately $0.94 \mathrm{Btu}$ per pound per degree Fahrenheit. (21,000 lbs.) ( 0.94 Btu per pound per degree Fahrenheit.) ( $59^{\circ}$ F.) $=116,500$ Btu. One ton of refrigeration is defined as $12,000 \mathrm{Btu}$ per hour. 
of the cabinet cooler to the top of the storage tank of approximately 8 feet. A flow of 21,000 pounds per hour can be maintained against a 15-foot head by a $1 / 2$-hp centrifugal pump.

Now that the major items of equipment for the receiving stage are selected, the next step is to estimate the 1953 cost of purchasing and installing them and to estimate the corresponding average annual depreciation cost. Rather

TABLE 9

EQUIPMENT LIST, INVESTMENT, AND ANNUAL DEPRECIATION FOR RECEIVING STAGE, PLANT I, 1953

\begin{tabular}{|c|c|c|c|c|c|c|}
\hline Item & Quantity & Description & List price & Total cost* & $\begin{array}{c}\text { Esti- } \\
\text { mated } \\
\text { life }\end{array}$ & $\begin{array}{l}\text { Annual } \\
\text { deprecia- } \\
\text { tion }\end{array}$ \\
\hline & & & dollars & dollars & yrs & dollars \\
\hline Can conveyor. & 1 & & 4,066 & 4,269 & 16 & 267 \\
\hline Weigh $\tan k \ldots \ldots \ldots \ldots$ & 1 & $500 \mathrm{lbs} \ldots \ldots \ldots \ldots \ldots$ & 2,180 & 2,289 & 12 & 191 \\
\hline Receiving vat... & 1 & $1,000 \mathrm{lbs} \ldots \ldots \ldots \ldots \ldots$ & 1,040 & 1,092 & 12 & 91 \\
\hline Scale $\ldots \ldots \ldots \ldots$ & 1 & $500 \mathrm{lbs} . \ldots \ldots \ldots \ldots$ & 838 & 880 & 17 & 52 \\
\hline Sample cabinet. & 1 & 480 bottles........... & 979 & 1,028 & 15 & 69 \\
\hline Can washer............... & 1 & $8 \mathrm{cpm} . \ldots \ldots \ldots \ldots$ & 4,965 & 5,213 & 17 & 307 \\
\hline Pump $\ldots \ldots \ldots \ldots \ldots \ldots \ldots$ & 1 & $11 / 2$ hp centrifugal. .... & 300 & 315 & 12 & 26 \\
\hline Filter............. & 1 duplex & $\begin{array}{l}21,000 \text { lbs per hr per } \\
\text { unit. } \ldots \ldots \ldots \ldots \ldots \ldots\end{array}$ & 1,082 & 1,136 & 15 & 76 \\
\hline Cabinet cooler. & 1 & $21,000 \mathrm{lbs}$ per $\mathrm{hr} \ldots \ldots$ & 5,946 & 6,243 & 18 & 347 \\
\hline Ammonia control. & 1 & 97 tons $\ldots \ldots \ldots \ldots \ldots$ & 1,728 & 1,814 & 18 & 101 \\
\hline Pump............ & 1 & $1 / 2 \mathrm{hp}$ centrifugal $\ldots .$. & 161 & 169 & 12 & 14 \\
\hline Itemized total.. & & & & 24,448 & & 1,541 \\
\hline $\begin{array}{l}\text { Miscellaneous and installa- } \\
\quad \text { tion } \nmid \ldots \ldots \ldots \ldots \ldots \ldots \ldots\end{array}$ & & & & 2,445 & & 154 \\
\hline Total installed cost $\ddagger$. & & & & 26,900 & & 1,700 \\
\hline
\end{tabular}

* Includes 3 per cent for sales tax and 2 per cent for freight cost.

t Includes cost of piping and wiring equipment.

$\ddagger$ Figures are rounded.

than apply a single depreciation rate to the cost of receiving equipment, individual rates are applied to each item separately. ${ }^{23}$

List prices were obtained from equipment companies. These prices are increased by 3 per cent for sales tax and 2 per cent average freight cost. ${ }^{24}$ Table 9 summarizes the results obtained for the receiving stage of Plant I, a total installed equipment cost of $\$ 26,900$ and an average annual depreciation of $\$ 1,700$.

${ }^{23}$ Rates appearing in "Income Tax Depreciation and Obsolescence, Estimated Useful Lives and Depreciation Rates," U. S. Bur. Internal Revenue Bulletin F, 93 pp.. Wash.: Govt. Print. Off., 1948; and Farrall, op. cit., p. 409, were used as guides in estimating useful life. Lacking any basis for estimating scrap value of equipment at the end of its useful life, the assumption is made that the scrap value is zero. The effect of this assump. tion on final results is negligible.

${ }^{24}$ While the 2 per cent allowance for freight cost may over- or underestimate the freight cost for particular items of equipment, it results in realistic allowances for stages and plants. 


\section{Evaporating Stage}

For purposes of estimation, the storage operation linking the receiving and evaporating stages is included in the evaporating stage. A selection of insulated storage tanks is made, which satisfies three desirable characteristics: (1) at least four tanks are provided so that such activities as filling, emptying, and standardizing can be properly scheduled; (2) a capacity at least equivalent to a single day's receipts during the flush month is provided; and (3) additional capacity is provided where necessary to allow flexibility in the number of days per month that the evaporating stage operates during months when the average daily receipts are less than that of the peak month. ${ }^{25}$ These characteristics are provided for Flant I by the selection of four 5,000-gallon storage tanks.

Since the operating rates of all of the equipment in the evaporating stage must conform to the operating rate of the evaporator, it is selected first. Capacity has been defined in terms of an eight-hour output. This means that the evaporator should have an input rate of 18,250 pounds of whole milk per hour during May, the month of peak milk receipts. The evaporator which most closely approximates this rate has a capacity for removing 9,900 pounds of water per hour. During May, 518 pounds of water are removed per 1,000 pounds of whole milk received.$^{26}$ Therefore, the corresponding May input rate for this evaporator is 19,100 pounds of whole milk per hour while the May output rate is 9,130 pounds of evaporated milk per hour. ${ }^{27}$ Thus, the average daily receipt for May would require that the evaporator operate for 7.6 hours.

Two preheaters are used, the first employing milk vapor from the evaporator as the heating medium and the second employing steam. Technical information furnished by an equipment company sufficed to prescribe for Plant I preheaters having 161 and 141 square feet of heating surface.

The friction head of the tubing and first preheater is estimated and added to the static head from the storage tanks to the hot well. A 2-hp pump is adequate for this function. Since the flow of milk into the hot well must correspond to the flow of milk into the evaporator and since this flow rate varies with the seasonal composition of milk receipts, a variable speed positive action pump is selected. A $3 / 4$-hp centrifugal pump is sufficient to recirculate the milk from the hot well to the second preheater and back to the hot well.

To allow for minor fluctuations in flow, a surge tank capable of holding ten minutes' evaporated milk output is selected to connect the evaporator and homogenizer. The homogenizer selected is capable of pumping evaporated milk at 2,500 psi at the same rate of output as the evaporator. The evaporated milk is forced by the homogenizer to a cabinet cooler which uses water as the coolant for the upper half of each leaf and ammonia for the lower half. The temperature drop is from approximately $140^{\circ} \mathrm{F}$ to $40^{\circ} \mathrm{F}$. If the milk is cooled to approximately $90^{\circ} \mathrm{F}$ by the water, 9,130 pounds of evaporated milk per

${ }^{25}$ See figures 12 and 13, pp. 678 and 679.

${ }^{28}$ See table 3 .

${ }^{27}$ (a) $9,900 \mathrm{lbs}$. of water per hr. times $1,000 \mathrm{lbs}$. of whole milk per $518 \mathrm{lbs}$. of water = $19,100 \mathrm{lbs}$. of whole milk per hr. (b) $19,100 \mathrm{lbs}$. of whole milk per hr. times $478 \mathrm{lbs}$. of evaporated milk per $1,000 \mathrm{lbs}$. of whole milk $=9,130 \mathrm{lbs}$. of evaporated milk per hour. 
hour cooled from $90^{\circ} \mathrm{F}$ to $40^{\circ} \mathrm{F}$ requires the extraction of $425,000 \mathrm{Btu}$ per hour or 35.4 tons of refrigeration. ${ }^{28}$ Ammonia controls which are capable of handling this refrigeration rate are selected.

From the cabinet cooler, the evaporated milk flows to storage tanks. Two selection criteria are used: (1) at least three tanks are needed to allow proper timing of filling, standardizing, and emptying, and (2) storage capacity is at least equal to the quantity of evaporated milk produced per day in May.

\section{TABLE 10}

EQUIPMENT LIST, INVESTMENT AND ANNUAL DEPRECIATION FOR EVAPORATING STAGE, PLANT I, 1953

\begin{tabular}{|c|c|c|c|c|c|c|}
\hline Item & Quantity & Description & List price & Total cost* & $\begin{array}{c}\text { Esti- } \\
\text { mated } \\
\text { life }\end{array}$ & $\begin{array}{c}\text { Annual } \\
\text { deprecia- } \\
\text { tion }\end{array}$ \\
\hline Storage tanks........... & 4 & 5,000 gallons $\ldots \ldots \ldots \ldots$ & 6,145 & 25,809 & 20 & 1,290 \\
\hline 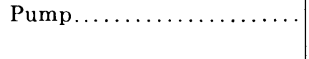 & 1 & $\begin{array}{l}2 \mathrm{hp} \text { positive action } \\
\text { variable speed } \ldots . . .\end{array}$ & 1,116 & 1,172 & 12 & 98 \\
\hline Hotwell........... & 1 & 500 gallons. . . . . . . . & 896 & 941 & 20 & 47 \\
\hline 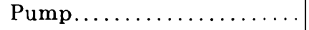 & 1 & $1 / 2 \mathrm{hp}$ centrifugal. & 200 & 210 & 12 & 18 \\
\hline Evaporator $† \ldots \ldots \ldots \ldots$ & 1 & 19,100 pounds per hour & 39,300 & 41,265 & 20 & 2,063 \\
\hline Surge tank... & 1 & 150 gallons. . . . . . . . & 600 & 630 & 20 & 32 \\
\hline Homogenizer............ & 1 & 9,130 pounds per hour & 5,969 & 6,267 & 15 & 418 \\
\hline Refrigerator tank......... & 1 & 2,000 gallons...... & 6,552 & 6,880 & 20 & 344 \\
\hline Itemized total $\ldots \ldots \ldots \ldots \ldots$ & & & & 106,640 & & 5,534 \\
\hline $\begin{array}{l}\text { Miscellaneous and installa- } \\
\text { tion } \ddagger \ldots \ldots \ldots \ldots \ldots \ldots \ldots\end{array}$ & & & & 5,332 & & 277 \\
\hline Total installed cost $\S \ldots \ldots \ldots$ & & & & 112,000 & & 5,810 \\
\hline
\end{tabular}

* Includes 3 per cent for sales tax and 2 per cent freight cost.

+ Cost of evaporator includes preheaters and auxiliary equipment.

† Includes piping and wiring equipment.

$\$$ Figures are rounded.

One 2,000-gallon and two 3,000-gallon tanks are selected for Plant I. In addition one 2,000-gallon refrigerated storage tank is provided to store concentrated skim milk.

The results of this analysis for Plant I are summarized in Table 10. Total evaporating stage installed equipment cost is $\$ 112,000$ with an annual depreciation of $\$ 5,810$.

\section{Canning Stage}

The can filler and sterilizer combination furnished the basis for the scale of plant. The combination selected for Plant I has an output rate of $160 \mathrm{cpm}$ or $31 / 3$ cases per minute. The only investment costs associated with the preheatersterilizer-cooler equipment are freight and installation costs since this is leased on a royalty basis. A can labeler, a can ejector for unlabeled cans, a

2. 9,130 lbs. of evaporated milk per hr. times 0.93 Btu per lb. per degree Fahrenheit times 50 degrees Fahrenheit $=425,000$ Btu per hr. or 35.4 tons of refrigeration:. 
TABLE 11

EQUIPMENT LIST, INVESTMENT, AND ANNUAL DEPRECIATION FOR CANNING STAGE, PLANT I, 1953

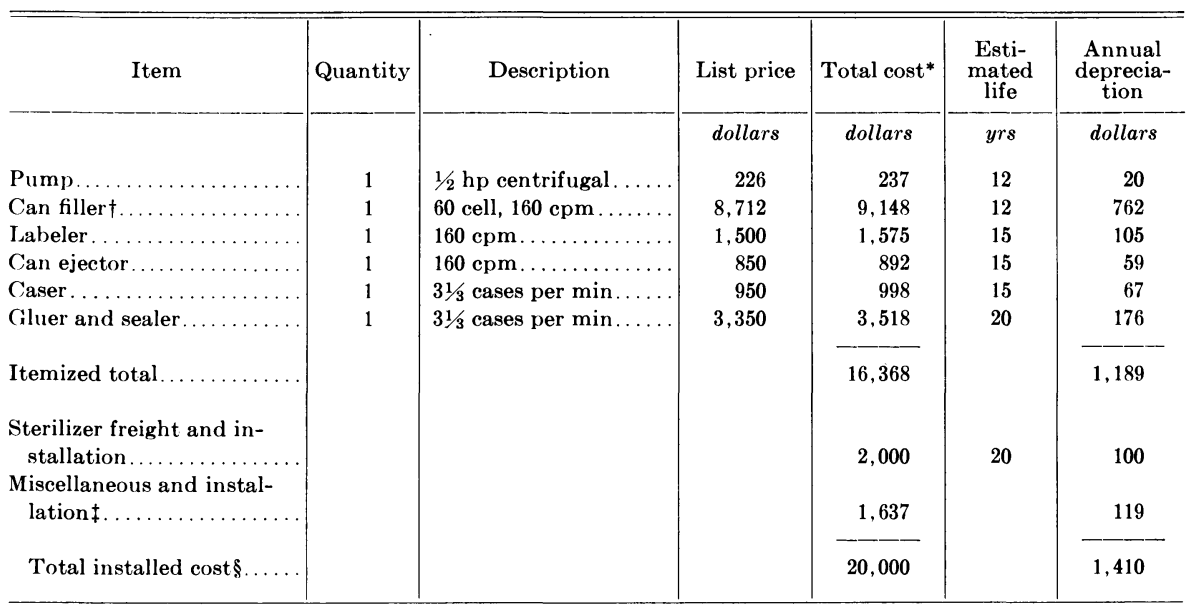

* Includes 3 per cent for sales tax and 2 per cent for freight cost.

$\dagger$ Includes leak detector and lightweight detector.

Includes piping and wiring equipment.

$\$$ Figures are rounded.

TABLE 12

CAPACITY OF UTILITY SY'STEMS

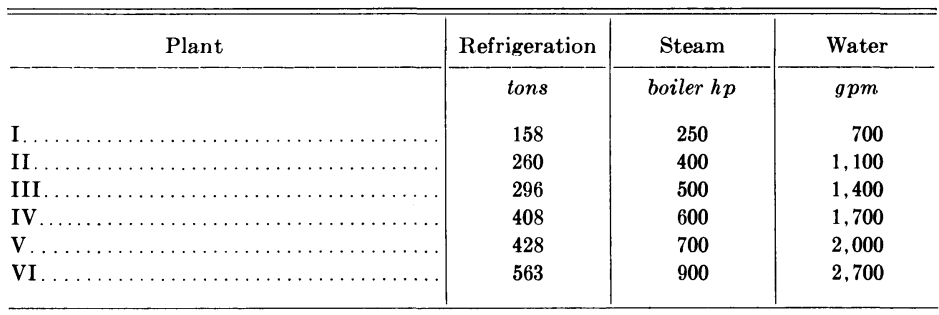

caser, and a gluer and sealer comprise the remaining items of equipment. These are selected to operate at the same rate as the can filler. The results for Plant I are summarized in Table 11. Total canning installed equipment cost is $\$ 20,000$ with an annual depreciation of $\$ 1,410$.

\section{Utility Stage}

For purposes of estimating equipment investment cost and annual depreciation, all equipment not listed in the preceding sections except office and laboratory equipment are included in the utility stage. Equipment is selected to meet the peak demands for the three utilities-refrigeration, steam, and water. In all cases an excess capacity of approximately 20 per cent is provided. Multiple steam boilers and refrigeration compressors are selected to avoid complete shutdown in case of unit failure and to provide output flexibility. Table 12 summarizes the capacities provided for each plant. 
An electric fork-lift truck of 4,000-pound lift capacity is provided for each plant to move pallets from and to the plant warehouse. Enough pallets are provided for each plant to store approximately 10 per cent of annual output.

The results for Plant I are summarized in Table 13. Total utility installed equipment cost is $\$ 95,500$ with an average annual depreciation of $\$ 5,390$.

TABLE 13

EQUIPMENT LIST, INVESTMENT, AND ANNUAL DEPRECIATION FOR UTILITY STAGE, PLANT I, 1953

\begin{tabular}{|c|c|c|c|c|c|c|}
\hline Item & Quantity & Description & List price & Total cost* & $\begin{array}{c}\text { Esti- } \\
\text { mated } \\
\text { life }\end{array}$ & $\begin{array}{c}\text { Annual } \\
\text { deprecia- } \\
\text { tion }\end{array}$ \\
\hline & & & dollars & dollars & yrs & dollars \\
\hline Refrigeration compressor. & 4 & $\begin{array}{r}6 \text { cylinders } 31 / 2 \times 31 / 2- \\
42.5 \text { tons } \ldots \ldots \ldots \ldots \ldots\end{array}$ & 4,345 & 18,249 & 20 & 912 \\
\hline Ammonia condenser. & 3 & evaporative -62 tons. . & 4,815 & 15,167 & 20 & 758 \\
\hline $\begin{array}{r}\text { Refrigeration miscellaneous, } \\
\text { and installation.......... }\end{array}$ & & & & 10,025 & 20 & 501 \\
\hline Steam boiler............ & 2 & $125 \mathrm{hp} \ldots$ & 10,578 & 22,214 & 20 & 1,111 \\
\hline $\begin{array}{l}\text { Boiler miscellaneous, and } \\
\text { installation............. }\end{array}$ & & & & 5,550 & 20 & 278 \\
\hline Water system ............ & 1 & 700 gal per $\min . . . . \ldots$ & & 12,100 & 20 & 605 \\
\hline Fork-lift truck . .......... & 1 & 4,000 lbs electric ....... & 8,000 & 8,400 & 10 & 840 \\
\hline Pallets.......... & 860 & $3^{\prime} \times 4^{\prime}$ wooden. . & 4.25 & 3.838 & 10 & 384 \\
\hline Total installed cost $\dagger \ldots .$. & & & & 95,500 & & 5.390 \\
\hline
\end{tabular}

* Includes 3 per cent for sales tax and 2 per cent for freight cost.

$\dagger$ Figures are rounded.

\section{Estimation of Equipment and Building Costs}

\section{Office and Laboratory Equipment Costs}

An alternative method is used to estimate equipment investment for the office and laboratory. There is no comparable technical information available to assist in the specification of particular items of equipment required for plants of various sizes. The basic data used to develop reasonable estimates are the purchase costs of office and laboratory equipment recorded for butter-powder plants in a cost study based largely on accounting data. The basic data are summarized in Table 14. These costs are based on 1946 prices and consequently need to be adjusted to reflect 1953 conditions. Price relatives are available for certain individual items of office equipment for the period following $1947 .^{20}$ These price relatives were used to estimate the cost of office equipment for the butter-powder Plant V at 1953 prices. The 1953 cost is approximately 139 per cent of the 1946 cost. All other cost figures are increased in the same proportion. ${ }^{30}$ Then the average relationship between

* See U. S. Bureau Labor Statistics, "Abbreviated Specifications for Individual Commodities." Wash.: Govt. Print. Off., 1955, 48 pp.; U. S. Bureau Labor Statistics, "Prices and Price Relatives for Individual Commodities in the Revised Index 1947-50." Wash.: Govt. Print. Off., 1952, and subsequent periodical issues.

${ }^{30}$ The same percentage increase was used for laboratory equipment. No price relatives are available for laboratory equipment with which to construct a separate index. 
TABLE 14

PURCHASE COST OF PLANT EQUIPMENT AT 1946 PRICES FOR THREE MODEL BUTTER-POWDER PLANTS

\begin{tabular}{c|c|c|c}
\hline \hline \multicolumn{1}{c|}{ Plant } & $\begin{array}{c}\text { Maximum } \\
\text { daily milk } \\
\text { receipts }\end{array}$ & $\begin{array}{c}\text { Office } \\
\text { equipment }\end{array}$ & $\begin{array}{c}\text { Laboratory } \\
\text { equipment }\end{array}$ \\
\hline & $1,000 \mathrm{lbs}$ & dollars & dollars \\
V $\ldots \ldots \ldots \ldots \ldots \ldots \ldots \ldots \ldots \ldots \ldots \ldots \ldots \ldots \ldots$ & 153.0 & 9,040 & 5.775 \\
VI $\ldots \ldots \ldots \ldots \ldots \ldots \ldots \ldots \ldots \ldots \ldots \ldots \ldots \ldots$ & 203.0 & 10,120 & 6,980 \\
VII $\ldots \ldots \ldots \ldots \ldots \ldots \ldots \ldots \ldots \ldots \ldots \ldots \ldots \ldots$ & 324.8 & 13,455 & 7,480 \\
\hline
\end{tabular}

Source: Walker, Scott H., et al. "An Economic Analysis of Butter-Nonfat Dry Milk Plants." Idaho Agr. Exp. Sta. Res. Bull. 20:26, 83. 1953.

\section{TABLE 15}

ESTIMATED INVESTMENT COSTS AND ANNUAL DEPRECIATION FOR OFFICE AND LABORATORY EQUIPMENT BY PLANTS, 1953

\begin{tabular}{|c|c|c|c|c|c|}
\hline \multirow{2}{*}{ Plant } & \multirow{2}{*}{$\begin{array}{l}\text { Maximum } \\
\text { daily milk } \\
\text { receipts }\end{array}$} & \multicolumn{2}{|c|}{ Office equipment } & \multicolumn{2}{|c|}{ Laboratory equipment } \\
\hline & & Cost & Depreciation & Cost & Depreciation \\
\hline & $1,000 \mathrm{lbs}$ & dollars & dollars & dollars & dollars \\
\hline I. & 146 & 12,000 & 800 & 8,200 & 550 \\
\hline II. & 237 & 15,500 & 1,030 & 9,400 & 630 \\
\hline III. & 292 & 17,700 & 1,180 & 10,100 & 670 \\
\hline IV ... & 356 & 20,200 & 1,350 & 10,900 & 730 \\
\hline V.... & 438 & 23,400 & 1,560 & 11.900 & 790 \\
\hline VI.... & 584 & 29,100 & 1,940 & 13,600 & 910 \\
\hline
\end{tabular}

maximum daily receipts and 1953 office equipment and 1953 laboratory equipment costs are estimated using the least-squares procedure. The resulting equations are:

$$
\begin{aligned}
& \mathrm{I}_{\mathrm{O}}=6.3+0.039 \mathrm{R} \\
& \mathrm{I}_{\mathrm{L}}=6.6+0.012 \mathrm{R}
\end{aligned}
$$

where $I_{O}$ and $I_{L}$ are equipment investment for office and laboratory measured in thousands of dollars and $R$ is maximum daily receipts measured in thousands of pounds of whole milk. These equations are used to estimate office and laboratory equipment costs for the six plants studied here. The results are summarized in Table 15. Annual depreciation for office and laboratory equipment is based on an average useful life of 15 years.

\section{Summary of Equipment Investment Cost and Annual Depreciation}

Total equipment investment and annual equipment depreciation costs are shown for each plant in Table 16. Equipment investment ranges from $\$ 274$,600 for a plant capable of processing 146,000 pounds of milk in approximately eight hours to $\$ 680,000$ for a plant capable of processing 584,000 pounds of milk in approximately eight hours. Equipment investment cost per 1,000 pounds of capacity ranges from about $\$ 1,880$ for Plant I to $\$ 1,160$ for Plant VI. 


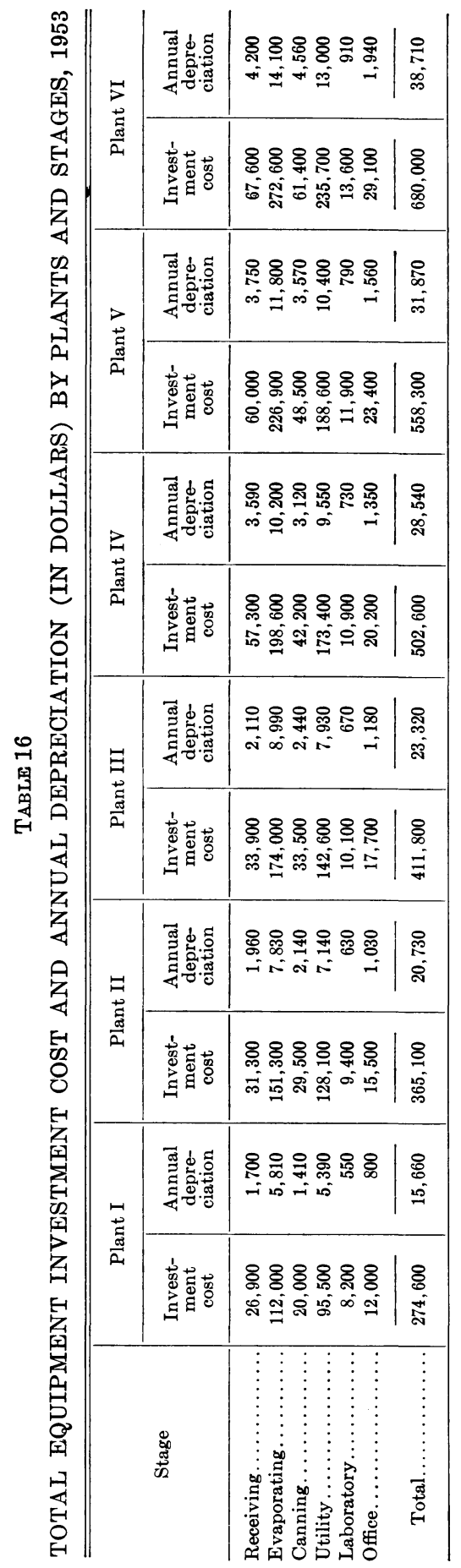


The average relationships between stage and total equipment investment costs and capacity of plant are of general interest. Table 17 contains equations derived from the data in Table 16 which can be used to estimate the investment required for stages having alternative capacities. ${ }^{31}$

To illustrate how the table can be used, suppose that an estimate is needed for the investment cost of evaporating stage equipment having an eight-hour

TABLE 17

PREDICTING EQUATIONS-EQUIPMENT INVESTMENT COST AS A FUNCTION OF EIGHT-HOUR CAPACITY, 1953

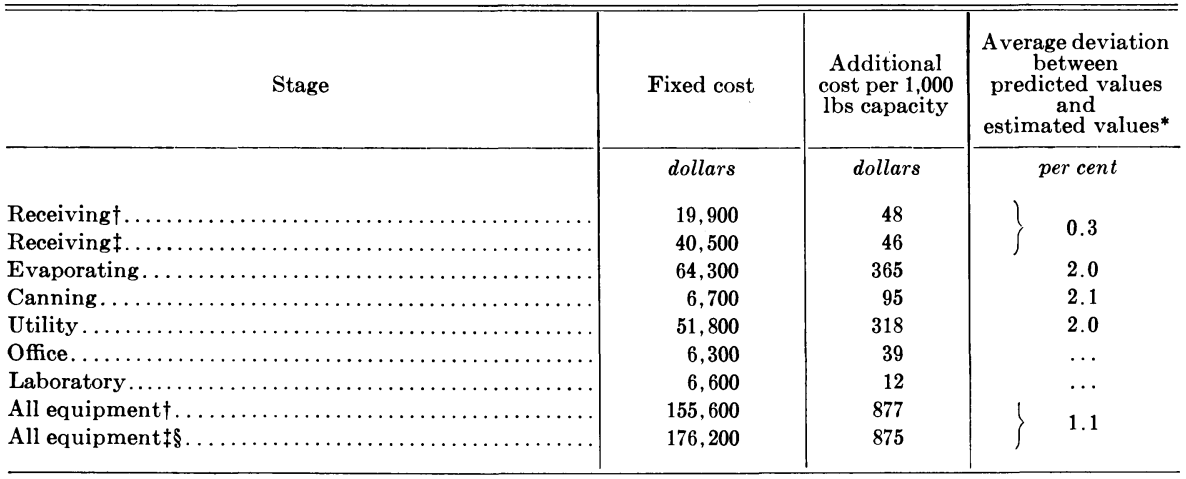

* The average deviation was found by using these equations to estimate the equipment investment cost for each plant and for each category by calculating the difference between these values and those found in Table 16 by expressing these differences as percentages of the values in Table 16, and finally by averaging these percentage differences disregarding their algebraic sign.

$\dagger$ For eight-hr capacities from 146,000 to $292,000 \mathrm{lbs}$ of milk.

$\ddagger$ For eight-hr capacities from 292,000 to $438,000 \mathrm{lbs}$ of milk.

$\S$ Sum of fixed and additional cost components for corresponding output ranges.

capacity of 300,000 pounds of milk. To the fixed cost, $\$ 64,300$, add the product of $\$ 365$ per 1,000 pounds capacity and 300,000 pounds capacity to obtain $\$ 64,300+\$ 109,500=\$ 173,800$.

Selected information contained in Table 17 is portrayed graphically in Figure 7. The approximate equipment investment cost for a utility stage associated with a plant handling 500,000 pounds of milk in eight hours is found by following the line leading vertically from 500 to its intersection with the slanted line marked "Evaporating" and then moving horizontally to the left edge of the chart to find the investment cost, $\$ 211,000$.

\section{Building Investment Cost}

In order to estimate building investment costs, it is necessary to estimate the floor space needed for each plant. This is done by developing tentative equipment layouts and floor plans. These plans are not to be interpreted as recommended or ideal. Alternative arrangements are possible, which would have little effect on total floor space and building investment costs.

The procedure used is to determine the floor space required for each piece of equipment and then to determine the approximate areas needed for par-

${ }^{31}$ These equations were derived by applying the method of least squares to the data in table 16 and the eight-hour capacities listed in table 15. 
ticular functions such as receiving, processing, canning, et cetera. These functions do not correspond exactly to the equipment stages. For example, part of the equipment belonging to the receiving stage is found in the receiving room, part in the processing room. These approximate areas are then used to develop specific floor plans for each plant. The general layout of each plant

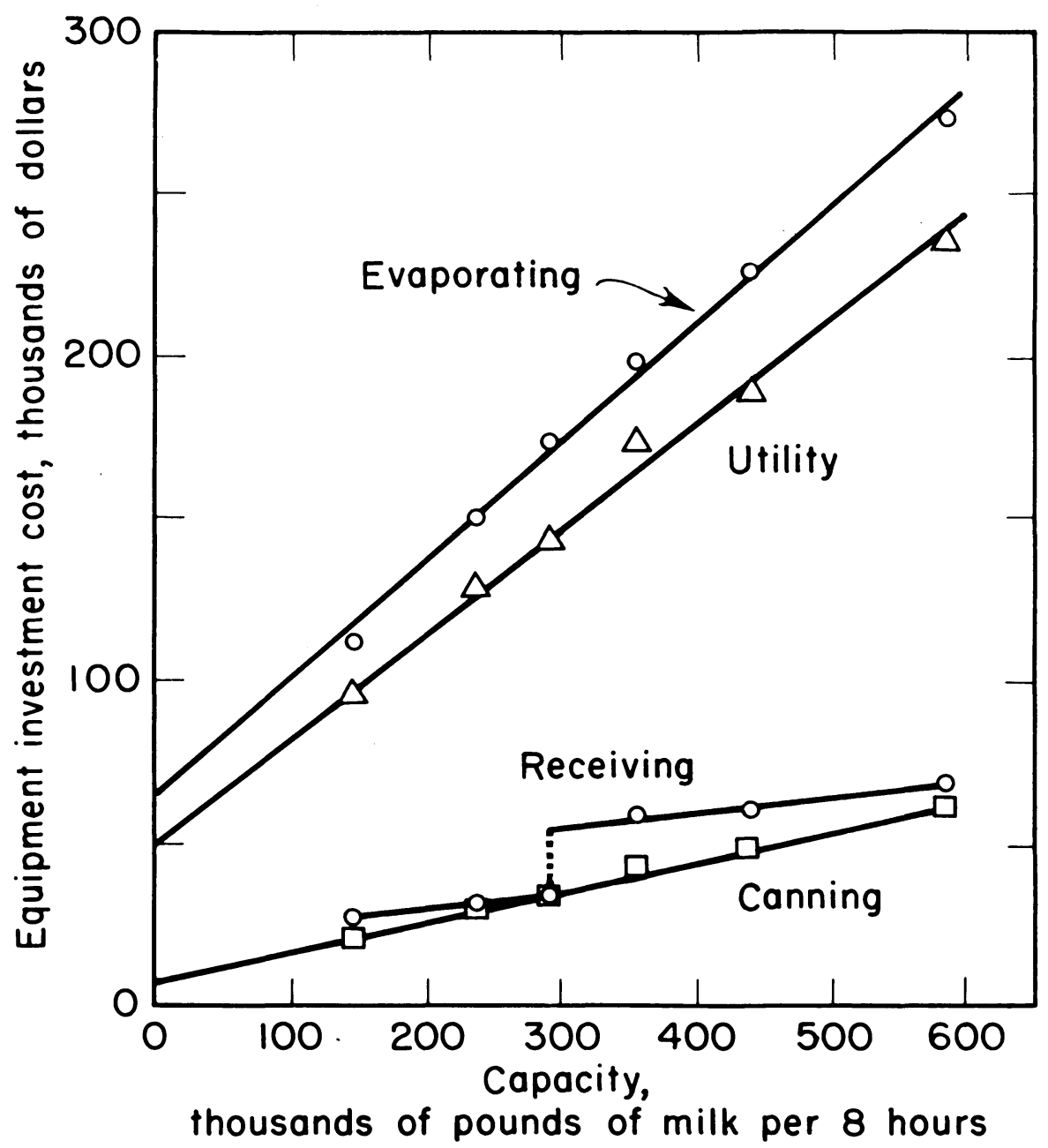

Fig. 7. Equipment investment cost functions for selected stages, 1953.

is approximately the same. Separate rooms are provided for the office, laboratory, locker, supplies, receiving, processing, utilities (including steam boilers and refrigeration compressors), and warehouse..$^{32}$ Although no separate partitions are provided, the warehouse contains space for the sterilizer and labeling and casing equipment. Sufficient floor space is available, in addition, to

${ }^{32}$ The separate rooms are, in general, the same as those found in California plants. 
store approximately 10 per cent of annual output. Sufficient floor space is available so that a minimum 3-foot distance can be maintained between adjacent equipment and between the equipment and walls. No special provision is made for potential plant expansion except that each plant has at least two sides where additional space could be added with relatively little disorganization of the existing plant. The floor plan for Plant I is shown in Figure 8. Equipment layout for the processing room for Plant $I$ is shown in Figure 9.

TABLE 18

DERIVATION OF BUILDING INVESTMENT COSTS BY PLANTS, 1953

\begin{tabular}{|c|c|c|c|c|c|c|c|}
\hline \multirow{2}{*}{ Item } & \multirow{2}{*}{ Cost rate } & \multicolumn{6}{|c|}{ Plant area } \\
\hline & & I & II & III & IV & V & VI \\
\hline & dollars per $s q f t$ & \multicolumn{6}{|c|}{$s q f t$} \\
\hline Building shell. ........ & $11,300+2.565 \mathrm{~A} \dagger$ & 13,200 & 17,600 & 20,300 & 24,000 & 28,500 & 36,300 \\
\hline Interior partitions ...... & 0.983 & 6,840 & 7,362 & 8,280 & 9,630 & 10,350 & 11,340 \\
\hline Ceiling.$\ldots \ldots \ldots \ldots \ldots$ & 0.678 & 5,600 & 6,580 & 7,500 & 9,425 & 12,000 & 12,400 \\
\hline Asphalt tile........... & 0.334 & 840 & 1,000 & 1,100 & 1,100 & 1,600 & 1,600 \\
\hline \multirow[t]{2}{*}{ Evaporator cupola walls } & 1.130 & 1,200 & 1,272 & 1,296 & 1,488 & 1,440 & 1,488 \\
\hline & & \multicolumn{6}{|c|}{ dollars } \\
\hline \multirow{2}{*}{\multicolumn{2}{|c|}{ 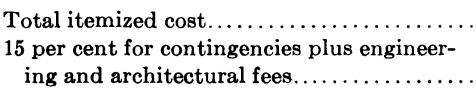 }} & 57,315 & 69,913 & 78,426 & 90,765 & 104,874 & 126,180 \\
\hline & & 8,597 & 10,487 & 11,764 & 13,615 & 15,731 & 18,927 \\
\hline \multicolumn{2}{|l|}{ Total construction cost*. } & 65,900 & 80,400 & 90,200 & 104,400 & 120,600 & 145,100 \\
\hline
\end{tabular}

* A is measured in thousands of square feet.

$\dagger$ Figures are rounded.

The estimation of building costs involves two steps: (1) estimating the cost of constructing a building shell of the proper dimension, and (2) estimating the cost of interior partitions, ceilings, and special floor coverings in addition to this preliminary estimate.

The cost of the building shell is estimated by the following equation based on data developed to estimate the construction cost of packing houses having a concrete slab at ground level, side walls of concrete, an 18-foot clear height to the underside of trusses, and a long-span roof construction. ${ }^{33}$

where $A=$ floor area in square feet.

$$
\text { Building cost }=\$ 11,300+2.565 \mathrm{~A}
$$

The coefficients in the original equation are $\$ 10,000$ and 2.27 . These are increased by 13 per cent to reflect the rise in material and labor costs from 1950 to 1953 . Table 18 lists the data used to estimate building investment costs

\footnotetext{
${ }^{33}$ Sammet, L. L., and I. F. Davis, "Building and Equipment Costs, Apple and Pear Packing." University of California, College of Agriculture, Agricultural Experiment Station, December, 1952. Giannini Foundation Mimeographed Report No. 141:38. (The fifth report in a series on "Efficiency in Fruit Marketing.") Estimates are derived in this publication for various types of building construction. The type selected for application here closely approximates that used for many dairy plants.
} 


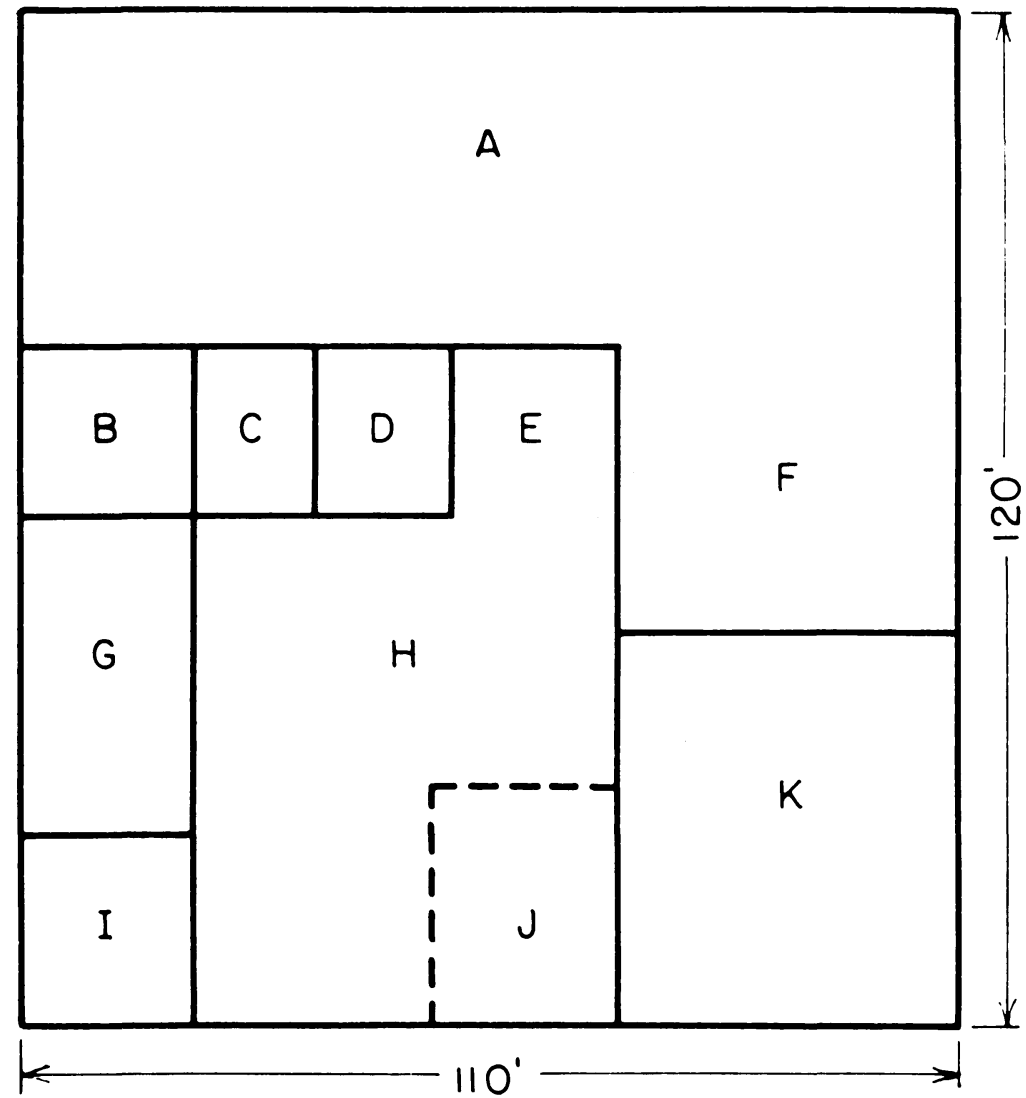

Fig. 8. Floor plan for Plant I.

and the corresponding cost estimates. The primary data are the number of square feet of floor space, interior partitions, ceiling, asphalt tile, and evaporator cupola wall required for each plant. The sum of these quantities multiplied by corresponding cost rates comprise the itemized building costs. These figures are then increased by 15 per cent to allow for contingencies and the engineering and architectural fees for preparing the detailed plant designs and specifications. Total building construction costs range from $\$ 65,900$ for a plant capable of processing 146,000 pounds of whole milk in approximately eight hours to $\$ 145,000$ for a plant capable of processing 584,000 pounds of whole milk in the same time period. Note that the average cost per 1,000 pounds of capacity drops from about $\$ 450$ for Plant I to slightly less than $\$ 250$ for Plant VI. This is due to two characteristics: (1) less space is required per unit of capacity, and (2) the cost per square foot is smaller in the larger plants.

Average relationships between these data are also of general interest. Two predicting equations are derived to predict the floor area and the construction costs required for plants having alternative eight-hour processing capacities. 


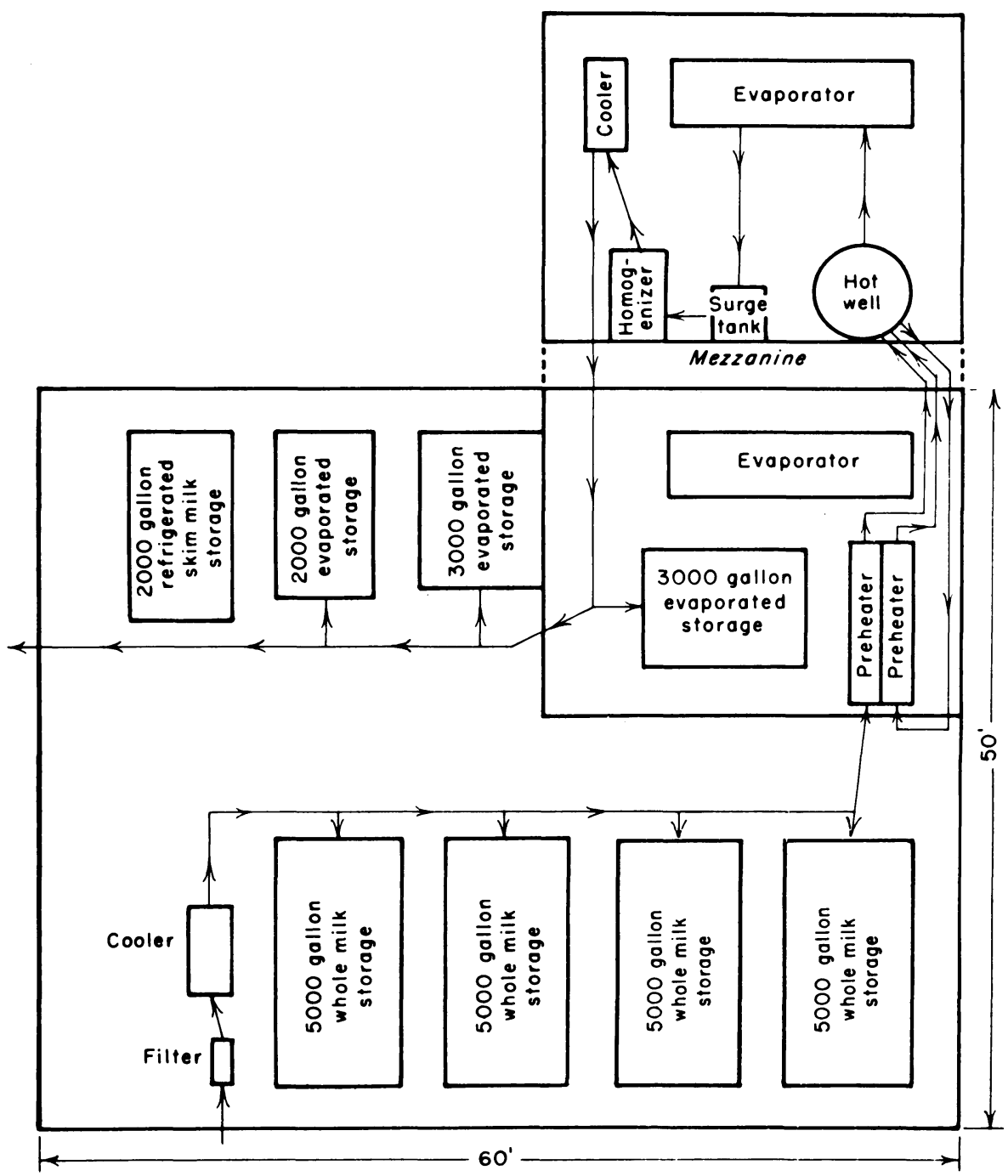

Fig. 9. Equipment layout for processing room of Plant I.

(The least squares procedure was applied to the data in Table 18 and the capacities shown in Table 15 to obtain the two predicting equations.) To estimate the floor space required for an evaporated milk plant of similar technology, add to the area, 5,100 square feet, the product: 53.2 square feet per 1,000 pounds capacity $\times$ capacity in thousands of pounds. Thus, a plant with an eight-hour capacity of 200,000 pounds of milk would require:

$$
5,100+(53.2)(200)=15,740 \text { square feet }
$$

The average relationship between capacity of plant and building construction costs can be expressed in a similar way. To estimate the 1953 building con- 


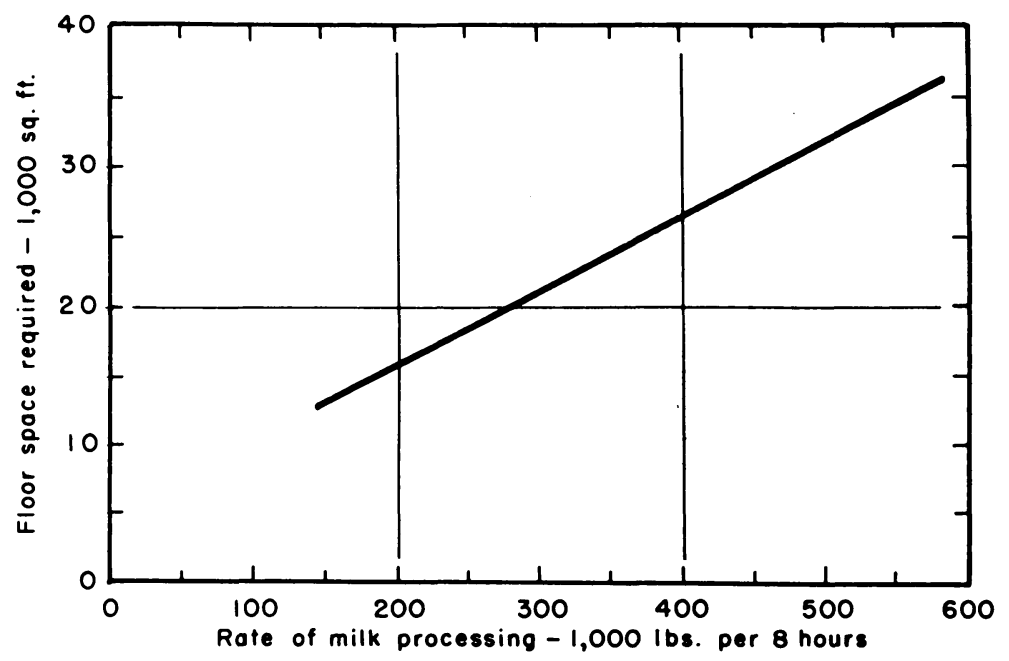

Fig. 10. Floor space requirement as a function of plant eapacity.

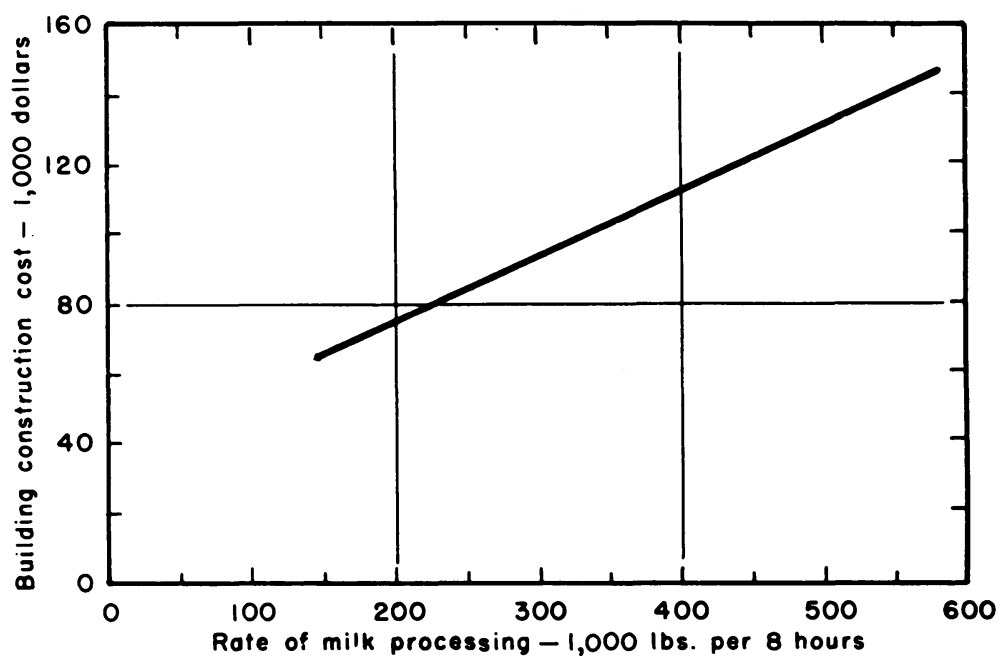

Fig. 11. Building construction cost as a function of plant eapacity, 1953.

struction costs for evaporated milk plants of similar technology to those analyzed here, add to the fixed cost, $\$ 37,900$, the product: $\$ 185$ per 1,000 pounds capacity $\times$ capacity in thousands of pounds. These average relationships are portrayed graphically in figures 10 and 11.

\section{Average Annual Fixed Costs of Equipment and Building}

One item in this category has already been estimated-average annual equipment depreciation. Those remaining are building depreciation, building and equipment repair and maintenance cost, interest cost on the undepreciated 

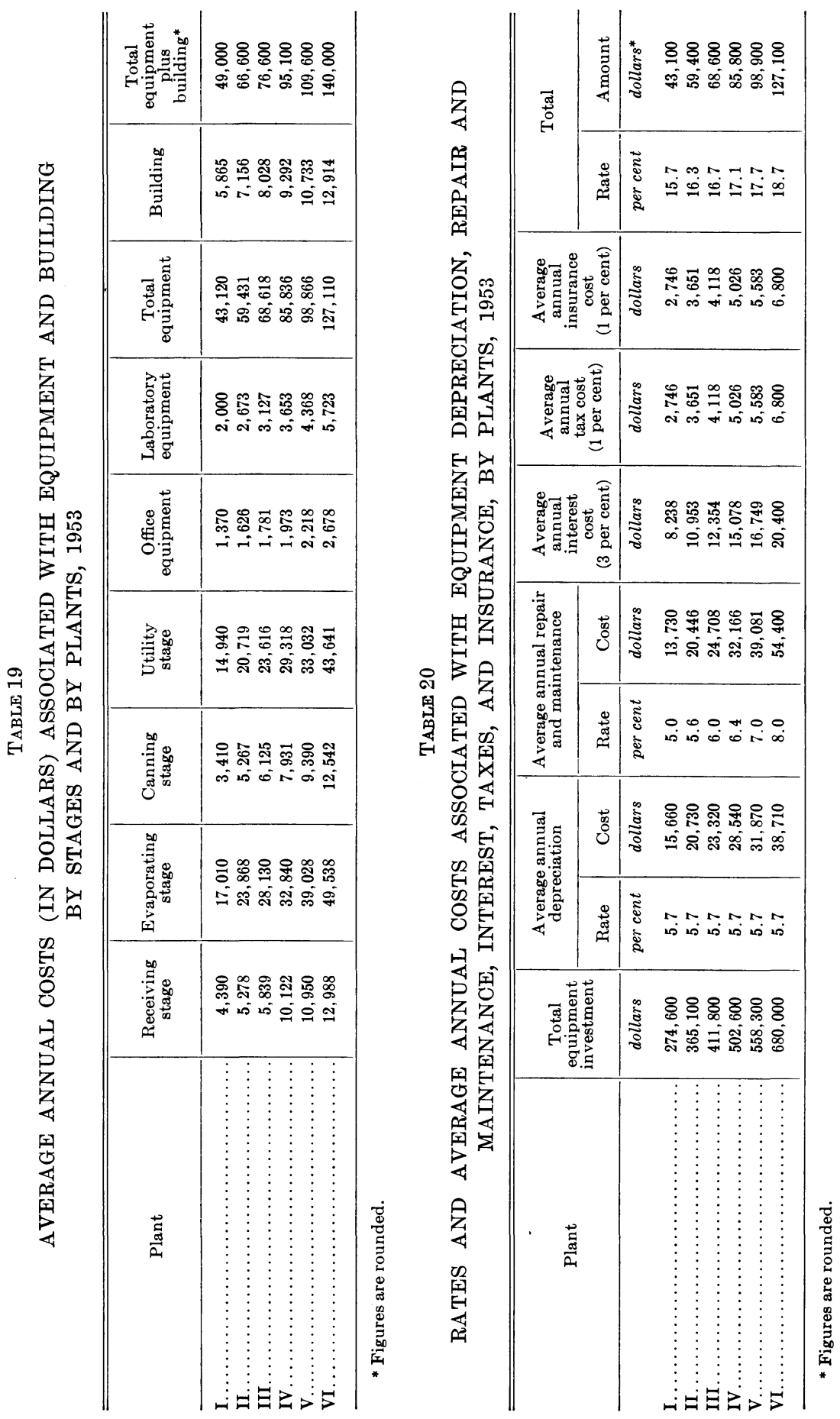
investment balance, and the costs of insurance and taxes. Two related items are omitted from this analysis. No attempt is made to estimate working capital for inventory and payroll or cost of site acquisition and development. (These items are omitted due to a lack of basic data from which to construct reasonable estimates. Land values are particularly influenced by local conditions. Both categories are relatively small and their omission will not affect the results significantly.)

The use life for a reinforced concrete building is estimated at forty years, equivalent to a depreciation rate of 2.5 per cent. Other average annual fixed costs are estimated to be 1.8 per cent of the original investment for repairs

TABLE 21

RATES AND ANNUAL AVERAGE COSTS (IN DOLLARS) ASSOCIATED WITH THE BUILDING DEPRECIATION, REPAIR AND MAINTENANCE, INTEREST, TAXES, AND INSURANCE, BY PLANTS, 1953

\begin{tabular}{|c|c|c|c|c|c|c|c|}
\hline Plant & $\underset{\text { investment }}{\text { Building }}$ & $\begin{array}{c}\text { Average } \\
\text { annual } \\
\text { depreciation } \\
\text { cost } \\
\text { (2.5 per cent) }\end{array}$ & $\begin{array}{c}\text { Average } \\
\text { annual } \\
\text { repair and } \\
\text { maintenance } \\
\text { cost } \\
(1.8 \text { per cent })\end{array}$ & $\begin{array}{c}\text { Average } \\
\text { annual } \\
\text { interest cost } \\
(3 \text { per cent })\end{array}$ & $\begin{array}{c}\text { Average } \\
\text { annual } \\
\text { tax cost } \\
(1 \text { per cent })\end{array}$ & $\begin{array}{c}\text { Average } \\
\text { annual } \\
\text { insurance } \\
\text { cost } \\
(0.6 \text { per cent })\end{array}$ & $\begin{array}{c}\text { Total } \\
(8.9 \text { per cent })\end{array}$ \\
\hline I $\ldots \ldots \ldots \ldots$ & 65,900 & 1,648 & 1,186 & 1,977 & 659 & 395 & 5,865 \\
\hline III. . . & 90,200 & 2,255 & 1,624 & 2,706 & 902 & 541 & 8,028 \\
\hline IV... & 104,400 & 2,610 & 1,879 & 3,132 & 1,044 & 626 & 9,292 \\
\hline V.... & 120,600 & 3,015 & 2,171 & 3,618 & 1,206 & 724 & 10,733 \\
\hline ViI.... & 145,100 & 3,628 & 2,612 & 4,353 & 1,451 & 871 & 12,914 \\
\hline
\end{tabular}

and maintenance, 0.6 per cent for insurance, 3 per cent for interest (approximately 5 per cent on the undepreciated balance), and 1 per cent for taxesmaking a total average annual fixed cost associated with the building of 8.9 per cent of its original investment cost. ${ }^{34}$

The average annual equipment depreciation has already been estimated. No attempt was made to differentiate explicitly that part of depreciation which is conceptually a function of time and that part which is a function of use. However, one crude adjustment is made which applies to this distinction. Several items of equipment are common to all six plants, resulting in a greater intensity of use in the larger plants. For example, the can-conveyor system is approximately the same in all plants, the weigh tank and scale are the same in the first three plants, the laboratory equipment is practically identical in all plants, and the fork-lift truck is common to all plants. With this in mind, the allowance for repair and maintenance is increased for the larger plants, ranging from 5 per cent per year of the original total equipment investment in the smallest plant to 8 per cent per year in the largest plant. Intermediate values are determined, which are proportional to the volume of milk handled. ${ }^{35}$

${ }^{34}$ Sammet, op. cit., p. 21.

${ }^{35}$ For a comparison with data developed primarily from accounting records, see Walker, et al., op. cit., p. . 35-36. Repair and maintenance rates for seven spray plants (also using evaporators) having maximum daily receipts from 61,000 to 325,000 pounds of milk per day are $4.59,4.66,4.81,5.28,5.49,5.86$, and 6.20 per cent. Butter powder Plant V has approximately the same capacity as Plant I. Butter-powder Plant VII is intermediate in capacity between Plants III and IV. 
The remaining average annual fixed cost rates associated with equipment are 1 per cent for insurance, 3 per cent for the average interest cost of undepreciated investment, and 1 per cent for taxes. ${ }^{36}$

Table 19 lists for each plant the average annual fixed costs associated with equipment and building. Tables 20 and 21 show the same total average annual fixed costs distributed according to the use to which the funds are budgeted.

\section{Section VI}

\section{ESTIMATION OF FIXED AND VARIABLE LABOR COST}

\section{Fixed Labor Cost}

\section{Management Cost}

Management for all six plants includes a general plant manager, an office superintendent, and a plant superintendent. Working foremen are included in the crew organization of the various stages of production. Managerial personnel receive annual salaries which have two reasonable characteristics: (1) they are significantly above the highest annual wage paid to the individuals supervised by management, and (2) they are positively correlated with size of plant.

To serve as a standard of comparison, a working foreman, at $\$ 1.921 / 2$ per hour receives approximately $\$ 4,000$ for 52 weeks at 40 hours per week (based on 1953 rate). Overtime, holiday pay, et cetra, could increase this figure to as much as $\$ 4,500$ per year. Reasonable management costs for Plant I are $\$ 6,500$, $\$ 5,500$, and $\$ 5,000$ respectively for plant manager, plant superintendent, and office superintendent. ${ }^{37}$ These costs are increased for the larger plants at approximately the rate of increase reported in the study just cited. Table 22 lists management cost for each plant.

\section{Office and Laboratory Labor Cost}

Work performed by office and laboratory personnel in evaporated milk plants is essentially similar to that performed in other milk plants. Lacking detailed accounting records from existing evaporated milk plants having a wide range of capacities and lacking detailed job descriptions and work standards to synthesize the number of personnel required, basic data from the butter-powder

${ }^{33}$ The percentages used for these categories are the same as those used by Sammet, op. cit., p. 21, and by R. G. Bressler in U. S. Bureau of Reclamation, op. cit., p. 88. An average interest rate of 3 per cent corresponds approximately to a rate of 5 per cent on the undepreciated balance. The corresponding percentages for the study cited in the preceding footnote are 1.205 per cent for insurance, 4.5 per cent for interest, and 2.8895 per cent for taxes. Insurance and tax rates are determined largely by the location and local conditions of a particular plant.

${ }^{37}$ For comparison, see Walker, et al., op. cit., pp. 39-40. Butter-powder Plants V, VI, and VII have combined annual management expenses for general manager and plant superintendent of $\$ 10,238, \$ 12,472$, and $\$ 15,173$. These expenses relate to 1948 and 1949 . Butter-powder Plant $\mathrm{V}$ has approximately the same maximum daily receipts of milk as Plant I. Butter-powder Plant VII is intermediate between Plants III and IV. 
study are used to estimate office and laboratory personnel requirements. ${ }^{3 *}$ Table 23 lists the basic data and corresponding estimates. The number of office personnel, including the office superintendent, ranges from four for Plant I to nine for Plant VI. The number of laboratory personnel ranges from two for Plant I to five for Plant VI.

TABLE 22

ANNUAL MANAGEMENT COST (IN DOLLARS) BY PLANTS, 1953

\begin{tabular}{c|c|c|c}
\hline \hline \multicolumn{1}{c|}{ Plant } & $\begin{array}{c}\text { Plant } \\
\text { manager }\end{array}$ & $\begin{array}{c}\text { Plant } \\
\text { superintendent }\end{array}$ & $\begin{array}{c}\text { Office } \\
\text { superintendent }\end{array}$ \\
\hline I. $\ldots \ldots \ldots \ldots \ldots \ldots \ldots \ldots \ldots \ldots \ldots \ldots$ & 6,500 & 5,500 & 5,000 \\
II $\ldots \ldots \ldots \ldots \ldots \ldots \ldots \ldots \ldots \ldots \ldots \ldots$ & 7,500 & 6,500 & 5,500 \\
III $\ldots \ldots \ldots \ldots \ldots \ldots \ldots \ldots \ldots \ldots \ldots$ & 9,000 & 7,000 & 6,000 \\
IV $\ldots \ldots \ldots \ldots \ldots \ldots \ldots \ldots \ldots \ldots \ldots$ & 10,000 & 7,500 & 6,500 \\
V $\ldots \ldots \ldots \ldots \ldots \ldots \ldots \ldots \ldots \ldots \ldots \ldots$ & 12,000 & 8,000 & 7,000 \\
VI $\ldots \ldots \ldots \ldots \ldots \ldots \ldots \ldots \ldots \ldots \ldots$ & 15,000 & 9,000 & 7,500 \\
\hline
\end{tabular}

TABLE 23

ESTIMATION OF THE NUMBER OF OFFICE AND LABORATORY PERSONNEL BY PLANTS

\begin{tabular}{|c|c|c|c|c|c|}
\hline Plant* & $\begin{array}{l}\text { Maximum } \\
\text { daily receipts } \\
\text { of milk }\end{array}$ & $\begin{array}{c}\text { Number of } \\
\text { office } \\
\text { personnel } \dagger \\
\text { including } \\
\text { office super- } \\
\text { intendent }\end{array}$ & $\begin{array}{c}\text { Number of } \\
\text { office } \\
\text { personnel } \\
\text { per } 1,000 \text { lbs } \\
\text { milk receipts }\end{array}$ & $\begin{array}{l}\text { Number of } \\
\text { laboratory } \\
\text { personnel } \dagger\end{array}$ & $\begin{array}{c}\text { Number of } \\
\text { laboratory } \\
\text { personnel } \\
\text { per } 1,000 \text { lbs } \\
\text { milk receipts }\end{array}$ \\
\hline & $1,000 \mathrm{lbs}$ & & & & \\
\hline IBP. & 60.9 & 2 & $1 / 30$ & 1 & $1 / 61$ \\
\hline IIBP... & 73.2 & 2 & $1 / 37$ & 1 & $1 / 73$ \\
\hline IIIBP. & 91.3 & 2 & $1 / 46$ & 1 & $1 / 91$ \\
\hline IVBP. & 121.8 & 3 & $1 / 41$ & 1 & $1 / 121$ \\
\hline I...... & 146 & 4 & $1 / 36$ & 2 & $1 / 73$ \\
\hline VBP. & 153.0 & 4 & $1 / 38$ & 2 & $1 / 77$ \\
\hline VIBP. & 203.0 & 5 & $1 / 41$ & 2 & $1 / 102$ \\
\hline II. ... & 237 & 5 & $1 / 47$ & 2 & $1 / 119$ \\
\hline III........ & 292 & 6 & $1 / 49$ & 3 & $1 / 97$ \\
\hline VIIBP... & 324.8 & 6 & $1 / 54$ & 3 & $1 / 108$ \\
\hline IV.... & 356 & 7 & $1 / 51$ & 3 & $1 / 118$ \\
\hline V. . & 438 & 8 & $1 / 55$ & 4 & $1 / 110$ \\
\hline VI. . & 584 & 9 & $1 / 65$ & 5 & $1 / 117$ \\
\hline
\end{tabular}

* Butter-powder plants are identified by BP.

$\dagger$ Boldfaced figures are those selected for evaporated milk plants.

No attempt is made to specify the number of junior, intermediate, senior, and principal clerks ${ }^{39}$ which comprise the office force of each plant. A representative salary which is applied to all office personnel except the office manager is $\$ 250$ per month, approximately the pay rate for senior clerks. This corresponds to a direct labor cost of $\$ 3,000$ per year. Additional typical costs per clerk are $\$ 84$ per year for welfare payments and $\$ 45$ per year for social security payments. Thus, average annual labor costs per clerk are estimated

ss See Walker, et al., op. cit., table 50, p. 86.

39 Monthly salaries for these categories are $\$ 197.65, \$ 222.65$, $\$ 252.65$, and $\$ 282.65$. 
to be approximately $\$ 3,130$. (There is some flexibility in scheduling part of the office work. It is assumed that this work is scheduled so that clerks are not replaced when on vacation. Office personnel are paid for but do not work on designated holidays.)

Laboratory personnel receive $\$ 1.82$ per hour. For a 40 -hour week, 52 weeks per year, this is equivalent to a direct annual wage of $\$ 3,786$. Additional annual costs are $\$ 84$ for welfare payments, $\$ 54$ for social security payments, $\$ 148$ for a replacement during two weeks' vacation, and $\$ 87$ for holiday pay. Average annual labor cost per laboratory worker is estimated to be approximately $\$ 4,160$.

Table 24 summarizes the annual labor costs for office and laboratory personnel, excluding office superintendent.

TABLE 24

ANNUAL LABOR COST OF OFFICE AND LABORATORY PERSONNEL BY PIAANTS, 1953

\begin{tabular}{|c|c|c|c|c|}
\hline Plant & $\begin{array}{l}\text { Number of } \\
\text { office } \\
\text { personnel, } \\
\text { excluding } \\
\text { office super- } \\
\text { intendent }\end{array}$ & $\begin{array}{l}\text { Annual labor cost } \\
\text { of office personnel, } \\
\text { excluding office } \\
\text { superintendent }\end{array}$ & $\begin{array}{l}\text { Number of } \\
\text { laboratory } \\
\text { personnel }\end{array}$ & $\begin{array}{c}\text { Annual } \\
\text { labor cost } \\
\text { of laboratory } \\
\text { personnel }\end{array}$ \\
\hline & & dollars & & dolli $i, s$ \\
\hline I. & 3 & 9,390 & 2 & 8,320 \\
\hline II. & 4 & 12,520 & 2 & 8,320 \\
\hline III. & 5 & 15,650 & 3 & 12,480 \\
\hline IV. & 6 & 18,780 & 3 & 12,480 \\
\hline V. & 7 & 21,910 & 4 & 16,640 \\
\hline VI. & 8 & 25,040 & 5 & 20,800 \\
\hline
\end{tabular}

\section{Utility Labor Cost}

The quantity of money invested in utility equipment is relatively large. Some items of utility equipment are likely to be operating at any time of the day or night. If equipment failure occurs when the equipment is untended, a serious loss of product or of invested capital is possible. For these reasons plants typically have at least one man on duty continuously. Four men are provided, each man working five days per week. One man works an additional eight hours of overtime per week. The wage rate for maintenance men is $\$ 1.87 \mathrm{per}$ hour. The relief man would receive an additional $\$ 0.05$ per hour and men working between 6:00 P.M. and 6:00 A.M. would receive an additional $\$ 0.10$ per hour. Thus, the effective average wage rate is approximately $\$ 1.98$ per hour. The annual direct utility labor cost is then $\$ 17,266$. (168 hours at $\$ 1.87$ per hour plus 8 hours at $\$ 0.935$ for overtime plus 84 hours at $\$ 0.10$ for night differential plus 40 hours at $\$ 0.05$ per hour for relief differential gives a direct cost per week of $\$ 332.04$. This amount divided by 168 hours gives $\$ 1.98$ per hour. $\$ 332.04$ times $52=\$ 17,266$.) Additional utility labor costs are $\$ 216$ for social security payments, $\$ 336$ for welfare payments, $\$ 285$ for holiday payments, and $\$ 634$ for cost of replacement during vacation. ( $\$ 54$ per person, $\$ 84$ per person, 144 holiday hours at $\$ 1.98$ per hour, and 320 vacation hours 
at $\$ 1.98$ per hour.) Annual utility labor cost is then approximately $\$ 18,740$ for each plant. (This corresponds to a weighted average cost rate of $\$ 2.14$ per hour.)

\section{Shipping Labor Cost}

A shipping-receiving clerk is in charge of receiving and storing supplies and shipping product. Basic wage rate for this position is $\$ 1.82$ per hour. Fiftytwo weeks at 40 hours per week would pay $\$ 3,786$. Additional costs are $\$ 84$ for welfare payments, $\$ 54$ for social security payment, and $\$ 87$ for holiday payment. (The shipping-receiving clerk can stock ample supplies to last during his two-week vacation. Other management personnel can supervise product shipment during his absence.) Total annual cost is $\$ 4,011$.

TABLE 25

SUMMARY OF ANNUAL AND DAILY FIXED LABOR COSTS (IN DOLLARS) BY PLANTS

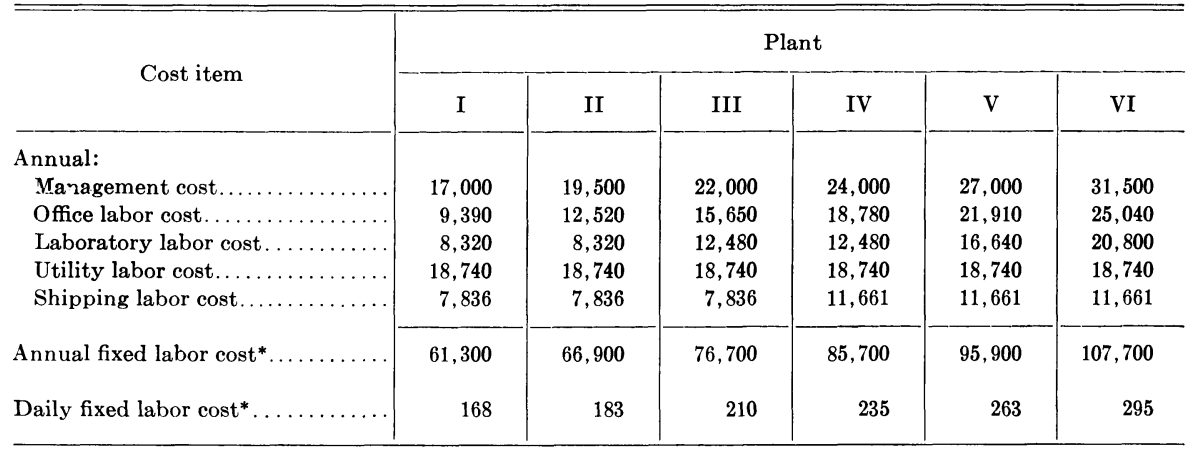

* Figures are rounded.

A fork-lift truck is used to transfer loaded pallets from the canning line to the warehouse and from the warehouse to trucks or railroad cars. Even in the largest plant, both of these jobs can be handled simultaneously by one truck and operator, providing shipping occurs only on the days when the canning line is operating. For this reason, labor cost for fork-lift operation is included in the section dealing with canning labor cost.

Standard rate for stacking cases in trucks or railroad cars is 450 cases per hour. One man working 40 hours per week, 52 weeks per year, can stack approximately 936,000 cases. This is approximately equal to the annual output of Plant III and one half the annual output of Plant VI. Thus, Plants I to III require one case stacker and Plants IV to VI require two.

Basic pay rate for case stackers is $\$ 1.67$ per hour. Annual labor cost for one case stacker is $\$ 3,474$ for straight time, $\$ 53$ for social security payment, $\$ 84$ for welfare payment, $\$ 80$ for holiday payment, and $\$ 134$ for vacation payment. Total annual cost per case stacker is $\$ 3,825$, equivalent to approximately $\$ 1.84$ per hour.

\section{Summary of Fixed Labor Cost}

Table 25 summarizes annual and daily fixed labor costs for each plant. Daily fixed labor costs range from $\$ 167$ for Plant I to $\$ 293$ for Plant VI. 


\section{Variable Labor Cost}

The procedure employed to estimate variable labor cost is: (1) to specify the crew organization for each stage and for each plant; (2) to schedule the number of days per month that each stage operates; (3) to estimate the corresponding input of man-hours per month; and (4) to use an average cost rate per man-hour to calculate total variable labor cost per year.

\section{Receiving Stage}

Seasonal variation in the quantity of milk received per day is associated with seasonal variation in the organization of the receiving crew. Plant I adjusts to a decrease in volume of daily milk receipts by reducing the number of shifts per day. The other plants adjust by reducing the size of crew.

Crew organizations are selected for particular plants and daily receipts so that: (1) no more than $4 \frac{1}{2}$ hours of receiving time are needed if a oneman crew is used, or 5 hours if a two-man crew is used, and (2) labor input is minimum.

The application of these criteria to Plant I results in the selection of one one-man shift per day during the period from November through January and two one-man shifts per day during the remainder of the year.

With an eight-cpm can washer, standard time for dumping cans of milk into the weigh tank is 0.1250 minute per can. For a one-man crew, standard time for weighing, sampling, and releasing the milk into the receiving vat is 0.1882 minute per sequence. If these two functions are performed at standard rates, the following equation is derived to show the operating time per shift for alternative quantities of milk received:

$$
\mathrm{T}=1.14+0.0321 \mathrm{R}
$$

where $\mathrm{T}$ is operating time in hours and $\mathrm{R}$ is milk receipts per shift measured in thousands of pounds..$^{\text {o }}$ To illustrate its use, the average quantity of milk received per shift during May is 73,000 pounds. Fixed operating time is 1.14 hours. Variable operating time is 2.34 hours, making a total operating time of 3.48 hours, corresponding to a flow rate of approximately 21,000 pounds per hour. This rate is possible only if the standard rates are maintained and the worker performs no other functions. In order to provide for other minor activity and for fatigue, standard operating time is increased by a delay allowance of 15 per cent. Thus, the time equation is modified to:

$$
\mathrm{T}=1.31+0.0369 \mathrm{R}
$$

This equation is used to estimate the operating time per shift for the receiving stage of Plant I. Its use indicates that the average daily milk receipts

${ }^{40}$ (a) $73,000 \mathrm{lbs}$. of milk $65 \mathrm{lbs}$. of milk /can $=1,123 \mathrm{cans}$

(b) $146,000 \mathrm{lbs}$. of milk

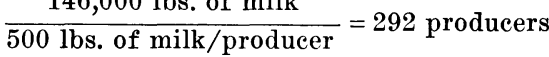

(c) (292 producers) (1.25 weighings/producer) $=365$ weighings

(d) Fixed time $=(365$ weighings $)(0.1882$ minutes $/$ weighing $)=68.7 \mathrm{~min} .=1.14 \mathrm{hrs}$.

(e) Variable time $=R(15.4$ cans $/ 1,000 \mathrm{lbs}$. of milk $)(0.1250 \mathrm{~min} . / \mathrm{can})$

$=\mathrm{R}(1.925 \mathrm{~min} . / 1,000 \mathrm{lbs}$. of milk $)$

$=\mathrm{R}(0.0321 \mathrm{hrs} . / 1,000 \mathrm{lbs}$. of milk $)$ 
for November through January can be received by one one-man shift per day with total operating time per shift (including delay allowance) not in excess of approximately $41 / 2$ hours.

This method is used to select crew organizations for the remaining plants. Standard can dumping times are 0.1 minute per can when a 10 -cpm can washer is specified and 0.0918 minute per ean with a 12-cpm can washer.

TABLE 26

CREW ORGANIZATION FOR RECEIVING STAGE BY TIME PERIODS AND PLANTS

\begin{tabular}{|c|c|c|c|c|c|c|}
\hline \multirow[b]{2}{*}{ Plant } & \multirow[b]{2}{*}{$\begin{array}{c}\text { Range in } \\
\text { daily receipts }\end{array}$} & \multirow[b]{2}{*}{ Time period } & \multicolumn{4}{|c|}{ Crew organization } \\
\hline & & & Shifts & $\begin{array}{c}\text { Number } \\
\text { of men } \\
\text { per shift }\end{array}$ & $\begin{array}{l}\text { Number } \\
\text { of can } \\
\text { washers }\end{array}$ & $\begin{array}{c}\text { Size } \\
\text { of can } \\
\text { washer }\end{array}$ \\
\hline & $1,000 \mathrm{lbs}$ & & & & & cpm \\
\hline \multirow[t]{2}{*}{ I... } & $83-87$ & November-January & 1 & 1 & 1 & 8 \\
\hline & $87-146$ & February-October & 2 & 1 & 1 & 8 \\
\hline \multirow[t]{2}{*}{ II. } & $135-156$ & Ọctober-February & 2 & 1 & 1 & 10 \\
\hline & $106-237$ & March-September & 2 & 2 & 1 & 10 \\
\hline \multirow[t]{2}{*}{ III. } & 166 & December-January & 2 & 1 & 1 & 12 \\
\hline & $166-292$ & February-November & 2 & 2 & 1 & 12 \\
\hline \multirow[t]{2}{*}{ IV. } & $202-270$ & September-March & 2 & 2 & 1 & 10 \\
\hline & $270-356$ & April-August & 2 & $\{2$ & 1 & 10 \\
\hline \multirow[t]{3}{*}{$\mathrm{V} \ldots \ldots \ldots \ldots \ldots$} & $249-289$ & October-February & 2 & 2 & 1 & 12 \\
\hline & $289-438$ & March-September & 2 & $\{2$ & 1 & 12 \\
\hline & & & & 1 & & 10 \\
\hline \multirow[t]{3}{*}{ VI. } & $332-442$ & September-March & 2 & 2 & 1 & 12 \\
\hline & $442-584$ & April-August & 2 & $\{1$ & 1 & 12 \\
\hline & & & & $\{4$ & 2 & 12 \\
\hline
\end{tabular}

TABLE 27

DAILY LABOR INPUTS FOR RECEIVING STAGE BY PLANTS-HOURS

\begin{tabular}{|c|c|c|c|c|c|c|c|c|c|c|c|c|}
\hline Plant & Jan. & Feb. & Mar. & Apr. & May & June & July & Aug. & Sept. & Oct. & Nov. & Dec. \\
\hline I. & 8 & 16 & 16 & 16 & 16 & 16 & 16 & 16 & 16 & 16 & 8 & 8 \\
\hline II. & 16 & 16 & 32 & 32 & 32 & 32 & 32 & 32 & 32 & 16 & 16 & 16 \\
\hline III. & 16 & 32 & 32 & 32 & 32 & 32 & 32 & 32 & 32 & 32 & 32 & 16 \\
\hline IV. & 32 & 32 & 32 & 48 & 48 & 48 & 48 & 48 & 32 & 32 & 32 & 32 \\
\hline V. & 32 & 32 & 48 & 48 & 48 & 48 & 48 & 48 & 48 & 32 & 32 & 32 \\
\hline VI........ & 48 & 48 & 48 & 64 & 64 & 64 & 64 & 64 & 48 & 48 & 48 & 48 \\
\hline
\end{tabular}

Dumper delay time for sampling, weighing, and releasing the milk is 0.04 minute per delay when a two-man crew is used.

Table 26 lists receiving crew organizations selected for each plant to match the corresponding ranges in daily milk receipts. Table 27 lists daily receiving labor inputs by plants and months. 


\section{Evaporating Stage}

Two men are assigned to the evaporating stage for each plant. One man operates the evaporator while the other assists in controlling the flow of whole milk from storage tanks and the flow of evaporated milk to storage tanks. The helper also cleans and sterilizes tanks, pipe lines, and other equipment when not otherwise occupied.

\section{Canning Stage}

Labor categories for the canning stage are working foreman, can feeder, filler operator, sterilizer operator, labeler and caser operator, case stacker, and fork-lift operator. Since the canning line is in continuous operation, extra personnel are needed for the larger crews to allow for personal and

TABLE 28

DIRECT PROCESSING CREW ORGANIZATIONS BY PLANTS

\begin{tabular}{|c|c|c|c|c|c|c|}
\hline \multirow{2}{*}{ Item } & \multicolumn{6}{|c|}{ Plant } \\
\hline & I & II & III & IV & $\mathrm{V}$ & VI \\
\hline & & & & & & \\
\hline \multicolumn{6}{|l|}{ Evaporating stage } & \\
\hline Evaporator operator............ & 1 & 1 & 1 & 1 & 1 & 1 \\
\hline Assistant evaporator operator.$\ldots \ldots \ldots \ldots \ldots$ & 1 & 1 & 1 & 1 & 1 & 1 \\
\hline \multicolumn{7}{|l|}{ Canning stage } \\
\hline Working foreman... & 1 & 1 & 1 & 1 & 1 & 1 \\
\hline Can feeder.......... & 2 & 3 & 3 & 4 & 5 & 6 \\
\hline Can filler operator... & 1 & 3 & 3 & 4 & 4 & 6 \\
\hline Sterilizer operator.............. & 1 & 1 & 1 & 1 & 2 & 2 \\
\hline Labeler and caser operator...... & 1 & 1 & 2 & 2 & 2 & 2 \\
\hline Case stacker....... & 1 & 1 & 1 & 1 & 2 & 2 \\
\hline Fork-lift operator. & 1 & 1 & 1 & 1 & 1 & 1 \\
\hline Relief $\operatorname{man} . . . . . .$. & 1 & 1 & 1 & 2 & 2 & 3 \\
\hline \multicolumn{7}{|l|}{ Cleaning stage } \\
\hline Cleaner..... & 1 & 1 & 2 & 2 & 3 & 3 \\
\hline Janitor. & 1 & 1 & 1 & 1 & 1 & 1 \\
\hline Total, direct processing. & 13 & 16 & 18 & 21 & 25 & 29 \\
\hline
\end{tabular}

fatigue time allowance. Standard rate for can feeders is approximately $100 \mathrm{cpm}$. Three operators are typically assigned to each pair of can fillers. One sterilizer operator is typically assigned for one or two sterilizers. For the smaller plants, one man operates the labeler and caser. For the larger plants, one man inserts labels into the labeler while a second man operates the caser. Standard rate for stacking cases on pallets is nine cases per minute. One fork-lift truck and operator are adequate for all plants.

\section{Cleaning Stage}

Although, when time permits, some cleaning and sterilizing of equipment is done by equipment operators, all plants require a cleaning crew to complete this work after the direct processing line is shut down. Modern plants 
clean many of their pipes and much equipment in place. Older plants still require a fairly large labor input to disassemble, hand clean, and reassemble equipment. Cleaning crews specified here utilize modern methods.

\section{Direct Processing Crew Organizations for Each of Six Plants}

Table 28 summarizes the direct processing crew organizations for each of the six plants. Variation in output per month is achieved by altering the number of days per month during which the direct processing stages operate, not by changing crew organization or rate of output per hour.

\section{Number of Processing Days Per Month}

Integration of the receiving and processing stages of Plant $I$ is illustrated by Figure 12. This chart traces the flow of milk from the receiving stage into raw-product storage, from raw-product storage through the evaporating stage into finished-product storage, and from finished-product storage into the canning stage. The height of the shaded areas indicates the volume of milk stored in each tank at every point of time during the day. The chart begins at midnight at which time the receipts from the preceding evening and a carry-over of 2,000 gallons of evaporated milk are stored. The evaporating and receiving stages begin at 7:00 A.M. while the canning stage begins at 9:00 A.M. ${ }^{41}$

Figure 13 illustrates the integration of receiving and processing stages for a day in March following a day during which no processing takes place. At 12:00 P.M. there are approximately 19,400 gallons of whole milk in storage, the amount of milk received during the preceding three receiving shifts. There are approximately 2,000 gallons of evaporated milk in storage. In order to handle this volume of stored milk, starting times for the evaporating and canning stages are moved up to 3:00 A.M. and 6:00 A.M., respectively. It is apparent that the storage capacity is almost fully utilized to allow Plant I to skip a processing day during March. Increased storage capacity would be required to be able to skip a processing day during months when the average daily receipt of milk is greater than that of March.

During March, Plant I produces 39,190 cases of evaporated milk. At 1,600 cases per eight-hour day, this amount can be produced in 25 days. So the processing stages of Plant I operate 25 days and are idle six days during March. This method is used to determine the number of operating days for all of the months during which average daily receipts are less than those of March. Table 29 summarizes the results. The same schedule applies to all plants.

${ }^{41}$ Data used to prepare the chart are:

Receipts per day........................ 17,000 gal.

Recipts per shift...................... 8,500 gal.

Receipts per hour........................ 2,100 gal.

Evaporator input rate..................... 2,220 gal. per hr.

Evaporator output rate.................... 1,030 gal. per hr.

Canning input rate....................... 985 gal. per hr.

Whole milk weighs approximately $8.6 \mathrm{lbs}$. per gal.

Evaporated milk weighs approximately 8.85 lbs. per gal. 


\section{Whole milk Evaporated milk}

Tank 1

5000 gals.
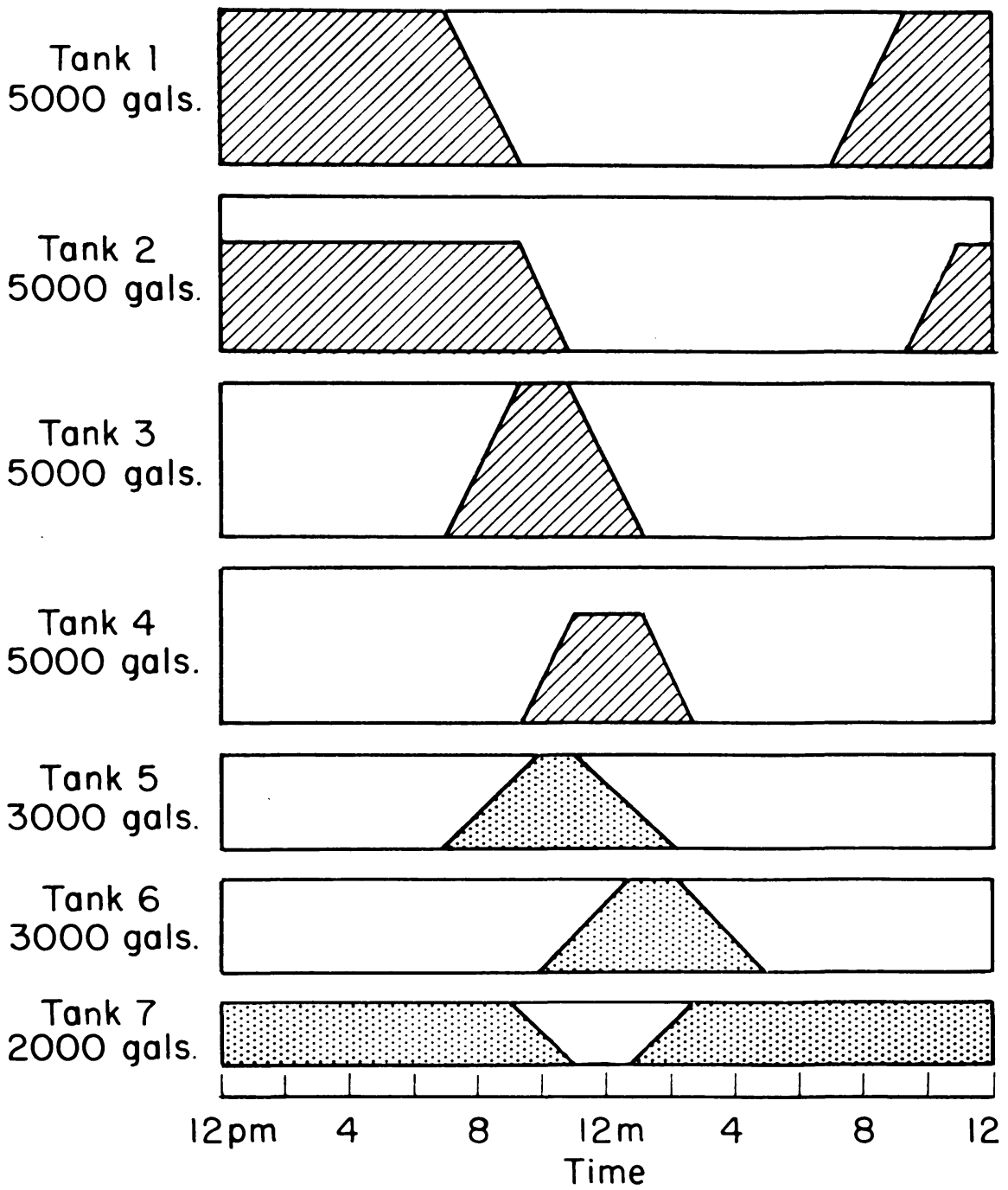

Fig. 12. Integration of processing stages through storage operations when processing occurs every day. 

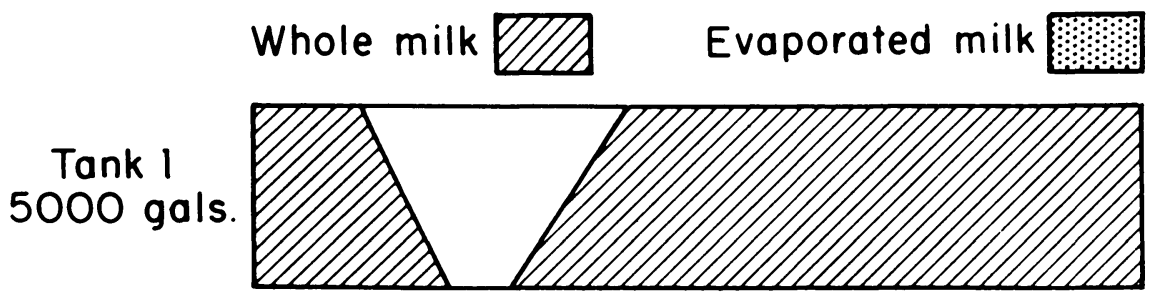

Tank 2 5000 gals.
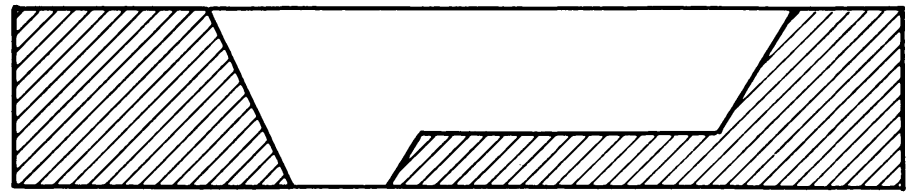

Tank 3 5000 gals.

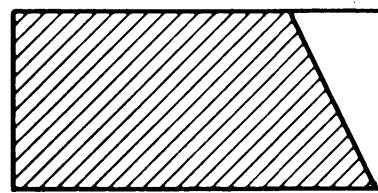

Tank 4 5000 gals.

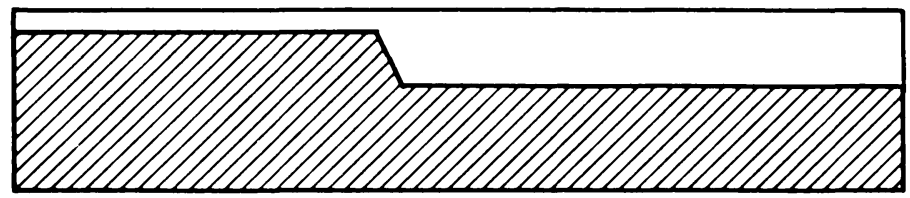

Tank 5 3000 gals.

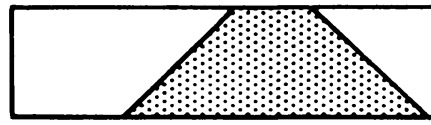

Tank 6 3000 gals.

Tank 7 2000 gals.
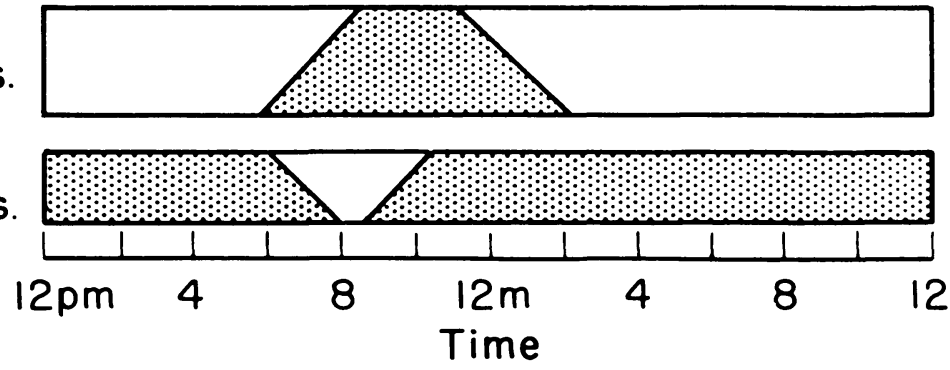

Fig. 13. Integration of processing stages when there has been no processing on previous day. 

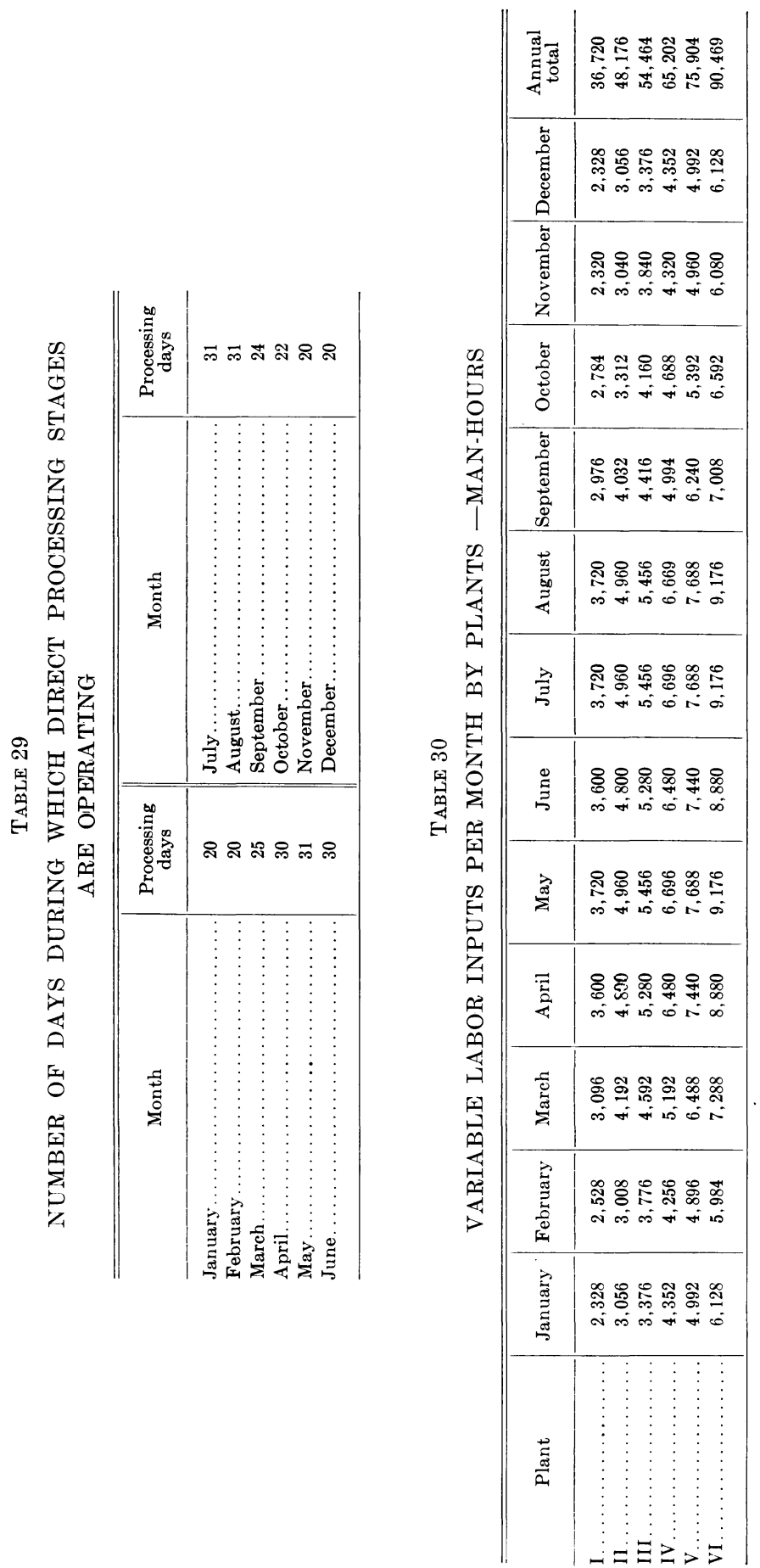


\section{Summary of Variable Labor Inputs}

Table 30 summarizes the variable labor input per month for each plant. The entries are calculated by multiplying the daily labor input for the receiving stage by the number of days in the month and adding the product of eight hours per man per day times the number of men in the processing erew times the number of processing days per month.

\section{Cost Rate Per Man-Hour}

Rather than attempt the complex classification of total variable man-hours worked per month into categories depending upon pay bracket, regular assignment or relief assignment, and day work or night work, the approxi-

TABLE 31

ANNUAL VARIABLE LABOR COST

BY PLANTS, 1953

\begin{tabular}{|c|c|}
\hline Plant & $\begin{array}{c}\text { Annual } \\
\text { variable } \\
\text { labor cost }\end{array}$ \\
\hline & dollars \\
\hline I. . & 75,600 \\
\hline II. & 99,200 \\
\hline III. & 112,200 \\
\hline 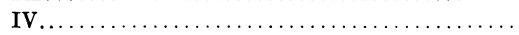 & 134,300 \\
\hline 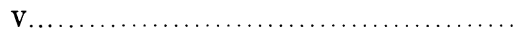 & 156,400 \\
\hline 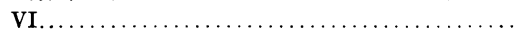 & 186,400 \\
\hline
\end{tabular}

mate weighted average wage rate of $\$ 1.80$ per hour is used. This rate applied to the annual total variable man-hours scheduled for Plant I gives an annual direct cost of $\$ 66,096$.

In order to reduce the number of relief men required during the months when milk is processed every day and, consequently, to provide a reasonable number of working days per man per month during the slack season, six working days per week per man are scheduled during the months from April through August when milk is processed every day. During these months, Plant I has a receiving and processing crew of $15 \mathrm{men}$. Three men are adequate to afford each of these 15 men at least one day off per week, making a total crew of 18 men.

As a result of this scheduling, approximately one out of every six manhours worked during the months from April through August are paid overtime rates. This results in an added cost for Plant I of $\$ 2,754 .^{42}$

Additional labor costs per man per year are $\$ 84$ for welfare payments, $\$ 54$ per year for social security payments, $\$ 144$ for two weeks' vacation, and $\$ 86$ for holiday payments, making a total of $\$ 368$ per man. The added cost for 18 men is $\$ 6,624$.

Thus, total annual variable labor cost for Plant $I$ is approximately $\$ 75,500$. This corresponds to a cost rate of $\$ 2.06$ per hour, approximately 14 per cent higher than the average wage rate. This cost rate is used to calculate annual variable labor costs for all the plants listed in table 31 .

$421 / 6(18,360$ man-hours $)(\$ 0.90$ per hr. $)=\$ 2,754$. 


\title{
Section VII \\ ESTIMATION OF FIXED AND VARIABLE SUPPLY COSTS
}

\author{
Fixed Supply Costs
}

\section{Office Supply Cost}

No attempt is made to estimate all the necessary quantities of laboratory, office, and cleaning supplies. Accounting data from evaporated milk plants, and technical data from which to construct reasonable estimates of the physical quantities needed of each of a long list of separate items, were not available. Consequently, estimates are based on a variety of sources.

In a cost study of butter-powder plants utilizing accounting data, office supply expenses for 12 plants during 1948 and 1949 ranged from 1 to 15 cents per thousand pounds of milk received. ${ }^{43}$ The weighted average cost for all plants was 7 cents per thousand. There was no clear tendency for the cost rate to decline for the larger plants.

The wholesale price index for office supplies and accessories of the Bureau of Labor Statistics increased from an average of 103 for 1948-49 to 112.4 in 1953, an increase of 9 per cent. A cost rate of 7.6 cents per thousand pounds of milk received, 9 per cent higher than the 1948-49 average, is used to estimate annual office supply cost for each of the six plants.

\section{Laboratory Supply Cost}

The cost of laboratory supplies per thousand pounds of milk received also varies considerably from one plant to another. It is relatively small and often is included in the category of general plant supplies rather than in a separate eategory. ${ }^{44}$ Principal determinants of laboratory supply cost are: (1) Number of producers; (2) Policy with respect to cumulating samples; (3) Method of receiving milk, i.e., in cans or bulk tanks; and (4) Variety and frequency of quality control tests.

Analysis of recent cost audits made by the California Bureau of Milk Control of three large fluid milk plants in the San Francisco Bay area reveal laboratory supply cost rates of $0.9,1.9$, and 1.6 cents per thousand pounds of milk received. These plants receive almost all their milk from relatively large producers in bulk tanks. Consequently, these rates are probably lower than those experienced by evaporated milk plants receiving milk from relatively small producers in 10-gallon cans.

In a recent economic study of the cost of receiving milk, laboratory supply cost for a plant receiving 114,000 pounds of milk per day in 10-gallon cans was estimated from accounting data to be 4.7 cents per thousand pounds of milk received. The estimate for a plant receiving 15,400 pounds of milk

${ }^{43}$ Walker, et al., op. cit., p. 15.

${ }^{4}$ For example, see Walker, et al., op. cit., p. 12. 
per day in bulk tanks was 2.3 cents per thousand pounds of milk received. ${ }^{45}$

In view of the evidence presented, a rate of 4 cents per thousand pounds of milk received is reasonably conservative and is used to estimate annual laboratory supply cost for each of the six plants.

Fixed supply costs are summarized in table 32 .

TABLE 32

ANNUAL OF'FICE AND LABORATORY SUPPLY

COST, BY PLANTS, 1953

\begin{tabular}{|c|c|c|}
\hline Plant & $\begin{array}{c}\text { Annual } \\
\text { office supply } \\
\text { cost* }\end{array}$ & $\underset{\substack{\text { Annual } \\
\text { cost* }}}{\text { laboratory supply }}$ \\
\hline & dollars & dollars \\
\hline $\mathbf{I} \ldots \ldots \ldots \ldots \ldots \ldots \ldots \ldots \ldots \ldots \ldots \ldots \ldots \ldots \ldots$ & 3,100 & 1,600 \\
\hline II $\ldots \ldots \ldots \ldots \ldots \ldots \ldots \ldots \ldots \ldots \ldots$ & 5,100 & 2,700 \\
\hline III $\ldots \ldots \ldots \ldots \ldots \ldots \ldots \ldots \ldots \ldots$ & 6,200 & 3,300 \\
\hline IV $\ldots \ldots \ldots \ldots \ldots \ldots \ldots \ldots \ldots \ldots$ & 7,600 & 4,000 \\
\hline $\mathrm{V}$. & 9,400 & 4,900 \\
\hline VI. . . . . & 12,500 & 6,600 \\
\hline
\end{tabular}

* Figures are rounded to the nearest hundred dollars.

In the butter-powder cost study, no separate estimate was made of laboratory supply cost. "General Factory Supply Expense" averaged 17 cents per thousand pounds of milk received for the 12 sample plants. Here, too, a wide range of rates was found, from 8 to 40 cents per thousand, with no apparent correlation with size of plant. ${ }^{40}$ In a later section, cleaning supply cost is here estimated to be 12 cents per thousand pounds of milk received. The sum of laboratory and cleaning supply cost rates, 16 cents per thousand, is fairly close to the average found in the butter-powder study.

An additional benchmark is available for comparison. One California evaporated milk plant experienced in 1951 a cost rate for general supplies of 23.1 cents per thousand pounds of milk received. This is also similar to the total used here, 23.6 cents per thousand.

\section{Variable Supply Costs}

\section{Cleaning Supply Cost}

One component of cleaning supplies is that used to clean the 10-gallon cans in which milk is delivered. One type of can washer uses 15 ce of an acid solution per can. This solution is prepared by mixing one quart of concentrate with 10 gallons of water. At $\$ 3$ per gallon of concentrate, and 65 pounds of milk per ean, this is equivalent to $\$ 0.38$ per thousand pounds of milk received and an annual cost for Plant I of $\$ 156.59 .^{47}$ The same rate is applied to each plant.

${ }^{45}$ Baum, E. L., R. D. Riley, and E. E. Weeks, "Economies of Scale in the Operation of Can and Tank Milk Receiving Rooms, with Special Reference to Western Washington." Washington Agr. Exp. Sta. Tech. Bul, 12:43, 47. 1954.

${ }^{4 n}$ Walker, et al., op. cit., p. 17.

${ }^{47}$ These data are taken from a technical bulletin issued by the equipment manufacturer. 
Estimates of daily cleaning costs for the remainder of the plant are based on notes taken from a series of reports given by industry members at a dairy conference at the University of California at Davis in 1953. Cleaning supply cost depends largely on the method of cleaning used. As an example of this and the kind of data made available, it was reported that spraycleaning a 25,000-pound per hour evaporator requires cleaning supplies costing $\$ 7.16$ compared with $\$ 20.65$ by the older hand method.

The estimate of total cleaning supply cost per operating day (excluding can washing supply cost) for Plant I is $\$ 16.00$. Annual cost for 304 operating days is $\$ 4,864$. Total annual cleaning supply cost is $\$ 5,000$ per year or 12 cents per thousand pounds of milk received or $\$ 0.011$ per case of evaporated milk. ${ }^{48}$ Table 33 lists the corresponding estimates of annual cleaning supply cost for 304 days operation for each of the plants.

\section{Packaging Supply Cost}

The number of cans, labels, cartons, et cetera, per case of evaporated milk is easy to determine. Price information is not so easily available. Cans may be purchased or produced. Quantity discounts may be available to the larger firms. Accounting data from one plant show total packaging cost per case of $\$ 1.19$. This figure is used for all six plants.

For several reasons, packaging supply cost is omitted from most of the subsequent analysis. In common with the milk components, packaging materials are included as a part of the physical product. Since the cost of milk is excluded, there is the feeling that the cost of packaging supplies should also be excluded. A more important reason is that other costs more directly result from internal operations of the plant. While the ratio between packaging supplies and output is fixed for all plants, other ratios are, to a greater extent, the result of managerial choices. Finally, the cost of packaging supplies per case of evaporated milk is large relative to processing cost per case and, if included, would tend to overshadow the later.

\section{Machinery Rental}

All the plants rent sterilizing equipment. Rates are $\$ 0.025$ per case for the first four plants using one or two sterilizers and $\$ 0.020$ per case for larger plants using three or more. (Detailed leasing arrangements between the equipment supplier and the evaporated milk companies are not available. The rates used above, however, are substantially correct.)

\section{Utility Costs}

The primary use of gas is to produce steam, an intermediate product used in several of the processing stages. Electricity, on the other hand, is used directly in each of the processing stages and is also used to produce intermediate products, steam, refrigeration, and water. Water is used in the production of steam and refrigeration. Steam, water, and electricity are also used in the cleaning stage.

The first step in estimating the total quantities of gas and electricity con-

${ }^{48} \$ 4864+156=\$ 5020 . \$ 5020 / 41,043$ thousand lbs. of milk $=12.23$ cents per thousand lbs. of milk. Figures in text are rounded. 
sumed per month is to estimate consumption rates per thousand pounds of milk received of electricity, steam, water, and refrigeration used in each of the stages. Then the steam consumption rates are added and converted to equivalent consumption rates of gas, electricity, and water. The refrigeration rates are added and converted to equivalent rates of electricity and water. Water rates are added and converted to an equivalent rate of electricity. Finally electricity rates are added to obtain the total electricity con-

TABLE 33

ANNUAL CLEANING SUPPLY COST, BY PLANTS, 1953

\begin{tabular}{|c|c|}
\hline Plant & $\underset{\substack{\text { Annual } \\
\text { cost* }}}{\text { Aning supply }}$ \\
\hline I. & $\$ 5,000$ \\
\hline II. . & 8,100 \\
\hline III. & 10,000 \\
\hline IV. . & 12,200 \\
\hline V... & 15,100 \\
\hline 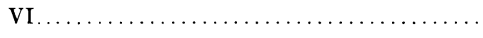 & 20,100 \\
\hline
\end{tabular}

* Annual milk receipts in thousands of pounds times $\$ 0.1223$ per thousand pounds, rounded to nearest hundred dollars.

sumption rate per thousand pounds of milk. Total gas and electricity rates are multiplied by monthly milk receipts to obtain total monthly gas and electricity consumption. These quantities are then valued by the cost rate schedules listed in Section II to obtain total monthly utility costs.

\section{Estimation of Electricity Consumption Rates and Cost}

Electrical consumption rates for pumping operations are computed from the following engineering equation:

$$
\mathrm{kw}=\frac{\mathrm{W} \times \mathrm{H} \times 0.746}{\mathrm{Em} \times \mathrm{Ep} \times 33,00}
$$

$\mathrm{W}=$ Weight of fluid in pounds per minute

$\mathrm{H}=$ Static head plus friction head in feet

$\mathrm{Em}=$ Efficiency of motor

$\mathrm{Ep}=$ Efficiency of pump ${ }^{40}$

For example, a 3-hp motor on an 8-cpm can washer pumps 180 gpm against a pressure or head of 40 feet. $^{50}$ Since 1 gallon of water weighs approximately 8.4 pounds, this is equivalent to 1,512 pounds per minute.

$$
\mathrm{kw}=\frac{(1512)(40)(0.746)}{(.8)(.6)(33,000)}=2.8^{51}
$$

\footnotetext{
${ }^{49}$ Farrall, op. cit., p. 62 . The equation in the text is in horsepower. One hp equals 0.746 kw.

${ }_{50}$ These specifications are taken from a technical bulletin issued by the equipment manufacturer.

${ }^{51}$ Motor efficiency of 0.8 and pump efficiency of 0.6 are reasonable estimates which imply an over-all efficiency of 0.48 .
} 
TABLE 34

ELECTRICITY CONSUMPTION RATES (IN KW) FOR RECEIVING STAGE, BY PLANTS

\begin{tabular}{|c|c|c|c|c|c|c|c|c|c|}
\hline \multirow{3}{*}{ Item } & \multicolumn{9}{|c|}{ Plant number and capacity of can washer } \\
\hline & \multirow{2}{*}{ Plant I } & \multirow{2}{*}{$\begin{array}{c}\text { Plant II } \\
10 \mathrm{cpm}\end{array}$} & \multirow{2}{*}{$\frac{\text { Plant III }}{12 \mathrm{cpm}}$} & \multicolumn{2}{|c|}{ Plant IV } & \multicolumn{2}{|c|}{ Plant V } & \multicolumn{2}{|c|}{ Plant VI } \\
\hline & & & & $8 \mathrm{cpm}$ & $10 \mathrm{cpm}$ & $8 \mathrm{cpm}$ & $12 \mathrm{cpm}$ & $12 \mathrm{cpm}$ & $12 \mathrm{cpm}$ \\
\hline Can washer*. & 5.2 & 8.6 & 9.8 & 5.2 & 8.6 & 5.2 & 9.8 & 9.8 & 9.8 \\
\hline Pump to coolert. & 0.6 & 0.8 & 1.0 & 0.6 & 0.8 & 0.6 & 1.0 & 1.0 & 1.0 \\
\hline Pump to tanks $\dagger$. & 0.4 & 0.4 & 0.5 & 0.4 & 0.4 & 0.4 & 0.5 & 0.5 & 0.5 \\
\hline Miscellaneous $\ddagger$. . & 1.0 & 1.0 & 1.5 & 1.0 & 1.0 & 1.0 & 1.5 & 1.5 & 1.5 \\
\hline \multirow[t]{2}{*}{ Total.. } & 7.2 & 10.8 & 12.8 & 7.2 & 10.8 & 7.2 & 12.8 & 12.8 & 12.8 \\
\hline & & & & \multicolumn{2}{|c|}{18.0} & \multicolumn{2}{|c|}{20.0} & \multicolumn{2}{|c|}{25.6} \\
\hline
\end{tabular}

* Electricity consumption rate for pump estimated from engineering equation. For drive motor and motor used for combined pump and air blower, kw per design hp.

$\dagger$ Estimated from engineering equation.

$\ddagger$ One kw per design hp.

TABLE 35

ELECTRICITY CONSUMPTION RATES FOR RECEIVING STAGE BY PLANTS AND TIME PERIODS

\begin{tabular}{|c|c|c|c|c|c|}
\hline Plant & Time period & $\begin{array}{c}\text { Receiving } \\
\text { rate }\end{array}$ & Crew & Organization & $\begin{array}{c}\text { Electricity } \\
\text { consump- } \\
\text { tion rate }\end{array}$ \\
\hline & & lbs milk/hr & & & $\begin{array}{l}\text { kwh/1,000 } \\
\text { lbs milk }\end{array}$ \\
\hline I. & All year & 21,000 & 1 man & $8 \mathrm{cpm}$ & 0.34 \\
\hline \multirow[t]{2}{*}{ II. } & Oct.-Feb. & 21,500 & $1 \mathrm{man}$ & $10 \mathrm{cpm}$ & 0.50 \\
\hline & Mar.-Sept. & 34,500 & 2 men & $10 \mathrm{cpm}$ & 0.31 \\
\hline \multirow[t]{2}{*}{ III. } & Dec.-Jan. & 22,000 & $1 \operatorname{man}$ & $12 \mathrm{cpm}$ & 0.58 \\
\hline & Feb.-Nov. & 37,300 & 2 men & $12 \mathrm{cpm}$ & 0.34 \\
\hline \multirow[t]{2}{*}{ IV. } & Sept.-Mar. & 34,500 & 2 men & $10 \mathrm{cpm}$ & 0.31 \\
\hline & April-Aug. & 55,500 & 3 men & $10 \mathrm{cpm}+8 \mathrm{cpm}$ & 0.32 \\
\hline \multirow[t]{2}{*}{ V. } & Oct.-Feb. & 37,300 & 2 men & $12 \mathrm{cpm}$ & 0.34 \\
\hline & Mar.-Sept. & 58,800 & 3 men & $12 \mathrm{cpm}+10 \mathrm{cpm}$ & 0.34 \\
\hline \multirow[t]{2}{*}{ VI. } & Sept.-Mar. & 59,300 & 3 men & $2-12 \mathrm{cpm}$ & 0.43 \\
\hline & April-Aug. & 74,600 & 4 men & $2-12 \mathrm{cpm}$ & 0.34 \\
\hline
\end{tabular}

Other electrical consumption rates are reported estimates based on measurement of operating equipment. For example, one company supplying refrigeration equipment reports that $0.87 \mathrm{kwh}$ is required per ton of refrigeration for operating conditions specified here.

Finally, in some cases rough estimates are made based on the design hp of electrical motors. A conservative procedure is to estimate a consumption rate of one $\mathrm{kw}$ per design $\mathrm{hp}$.

Tables 34 and 35 summarize estimates of electricity consumption for the receiving stage. 
The homogenizer uses most of the electricity required for the evaporating stage. A pressure of 2,500 psi (pounds per square inch) is equivalent to 57,750 feet of head. At a rate of 10,000 pounds of evaporated milk per hour, a 90 per cent motor efficiency and an 85 per cent pump efficiency, the electricity consumption rate is:

$$
\frac{\left(\frac{10,000}{60}\right)(57,750)(.746)}{(.90)(.85)(33,000)}=28.4 \mathrm{kw}
$$

Thus, $2.84 \mathrm{kwh}$ per thousand pounds of evaporated milk is the rate used for all plants.

At $70^{\circ} \mathrm{F}, 403$ gallons of condensing water are required per thousand pounds of whole milk evaporated..$^{52}$ In a later section, 330 pounds of steam

TABLE 36

ELECTRICITY CONSUMPTION RATES (kwh/hr) FOR EVAPORATING STAGE, BY PLANTS

\begin{tabular}{|c|c|c|c|c|c|c|}
\hline Item & Plant I & Plant II & Plant III & Plant IV & Plant V & Plant VI \\
\hline Tank agitators*. & 2.0 & 3.0 & 4.0 & 4.0 & 4.0 & 4.0 \\
\hline Pump to preheatert.............. & 0.7 & 0.9 & 1.7 & 1.8 & 1.2 & 2.0 \\
\hline Recirculating pump $\dagger \ldots \ldots \ldots \ldots \ldots$ & 0.5 & 0.8 & 1.2 & 1.3 & 0.8 & 1.8 \\
\hline Evaporation unload $\dagger \ldots \ldots \ldots \ldots \ldots$ & 0.3 & 0.5 & 0.7 & 0.8 & 0.8 & 1.0 \\
\hline Condensate unload $\dagger$. & 2.1 & 3.4 & 4.5 & 5.0 & 5.3 & 7.4 \\
\hline Homogenizer $\dagger$. & 25.9 & 42.6 & 55.1 & 61.9 & 64.7 & 91.7 \\
\hline Total. & 31.5 & 51.2 & 67.2 & 74.8 & 76.8 & 107.9 \\
\hline $\begin{array}{l}\text { Evaporator input rate } 1,000 \mathrm{lbs} \\
\mathrm{milk} / \mathrm{hr} \ldots \ldots \ldots \ldots \ldots \ldots \ldots\end{array}$ & 19.1 & 31.3 & 40.5 & 45.7 & 47.8 & 67.6 \\
\hline $\mathrm{kwh} / 1,000 \mathrm{lbs}$ milk & 1.65 & 1.64 & 1.66 & 1.64 & 1.61 & 1.60 \\
\hline
\end{tabular}

* One' kw per design hp.

† Estimated from engineering equation.

per thousand pounds of milk is the estimated rate. Also, approximately one half of the milk input is changed to vapor and later condensed. Therefore, approximately 4,200 pounds of condensate per hour must be pumped from the evaporator per thousand pounds of whole milk evaporated. Application of the pumping formula results in an estimate of $0.11 \mathrm{kwh}$ per thousand pounds of whole milk for unloading condensate from the evaporator.

Tables 36 and 37 summarize electricity consumption rates for the evaporating and canning stages of all plants.

Cleaning operations have not been specified in sufficient detail to synthesize electricity consumption rates. A reasonably conservative estimate is provided by the quantity of electricity used by the evaporating stage during a two-hour period, excluding the homogenizer. ${ }^{53}$ For example, the evaporating stage of Plant I, excluding the homogenizer, uses approximately $6 \mathrm{kw}$

\footnotetext{
${ }^{52}$ An average between the rates listed by an equipment company for $55^{\circ}$ and $85^{\circ}$ condensing water.

${ }^{53}$ Using spray cleaning, the evaporator is operated for approximately 30 minutes.
} 
TABLE 37

ELECTRICITY CONSUMPTION RATES (kwh/hr) FOR CANNING STAGE, BY PLANTS

\begin{tabular}{|c|c|c|c|c|c|c|}
\hline Item & Plant I & Plant II & Plant III & Plant IV & Plant V & Plant VI \\
\hline Pump*. & 0.2 & 0.3 & 0.4 & 0.5 & 0.6 & 0.7 \\
\hline Can fillert. & 0.8 & 1.5 & 1.5 & 2.3 & 2.3 & 3.0 \\
\hline Sterilizer $\dagger \ldots \ldots \ldots \ldots \ldots \ldots \ldots \ldots$ & 8.5 & 17.0 & 17.0 & 17.0 & 25.5 & 34.0 \\
\hline Canning line $† \ldots \ldots \ldots \ldots \ldots \ldots$ & 2.6 & 2.6 & 3.0 & 3.0 & 3.4 & 5.8 \\
\hline Misc. $\dagger \ldots \ldots \ldots \ldots \ldots \ldots \ldots \ldots$ & 1.0 & 1.0 & 1.0 & 1.0 & 2.0 & 2.0 \\
\hline Total... & 13.1 & 22.4 & 22.9 & 23.8 & 33.8 & 45.5 \\
\hline Output rate (cases/hr). & 200 & 325 & 400 & 487.5 & 600 & 800 \\
\hline $\mathrm{kwh} /$ case.............. & 0.0655 & 0.0689 & 0.0573 & 0.0488 & 0.0563 & 0.0569 \\
\hline $\mathrm{kwh} / 1,000 \mathrm{lbs}$ milk $\ddagger \ldots \ldots \ldots$ & 0.75 & 0.79 & 0.65 & 0.56 & 0.64 & 0.65 \\
\hline
\end{tabular}

* Estimated from engineering equation.

† One kw per design hp.

\$ Previous line multiplied by 11.42 cases per $1,000 \mathrm{lbs}$, the average yield.

TABLE 38

ELECTRICITY CONSUMPTION RATES FOR STEAM PRODUCTION BY PLANTS AND TIME PERIODS

\begin{tabular}{|c|c|c|}
\hline Plant & Time period & $\begin{array}{c}\text { Electricity } \\
\text { consumption } \\
\text { rate }\end{array}$ \\
\hline & & $\begin{array}{l}\text { kwh } / 1,000 \\
\text { lbs milk }\end{array}$ \\
\hline I. ....... & All year & 1.44 \\
\hline II. & $\begin{array}{l}\text { October-February } \\
\text { March-September }\end{array}$ & $\begin{array}{l}1.46 \\
1.42\end{array}$ \\
\hline$\ldots \ldots \ldots \ldots$ & $\begin{array}{l}\text { December-January } \\
\text { February-November }\end{array}$ & $\begin{array}{l}1.47 \\
1.43\end{array}$ \\
\hline IV. & $\begin{array}{l}\text { September-March } \\
\text { April-August }\end{array}$ & $\begin{array}{l}1.42 \\
1.43\end{array}$ \\
\hline V. . & $\begin{array}{l}\text { October-February } \\
\text { March-September }\end{array}$ & $\begin{array}{l}2.09 \\
2.10\end{array}$ \\
\hline VI. & $\begin{array}{l}\text { September-March } \\
\text { April-May }\end{array}$ & $\begin{array}{l}2.11 \\
2.09\end{array}$ \\
\hline
\end{tabular}

per hour. For 304 operating days this corresponds to 3,650 kwh per year or an average of $0.09 \mathrm{kwh}$ per thousand pounds of milk. This rate is used for all plants.

For the steam boilers, selected for the various plants, the first four plants require $2.6 \mathrm{kwh}$ per thousand pounds of steam while the two largest plants require $3.8 \mathrm{kwh}$ per thousand pounds of steam. ${ }^{54}$ Using the steam requirements estimated in a later section, electricity consumption rates per thousand pounds of milk are computed from these rates per thousand pounds of steam. The results are summarized in table 38 .

\footnotetext{
${ }^{\text {it }}$ One kwh per design hp.
} 
Electricity consumption rates for refrigeration vary from month to month in response to variation in temperature and in the percentage of milk receipts cooled. Based on refrigeration estimates made in a later section, table 39 summarizes electricity consumption rates for refrigeration. A conversion rate of $0.87 \mathrm{kwh}$ per ton of refrigeration is used..$^{55}$

There is a small seasonal variation in water requirements in response to variation in refrigeration requirements. Relative to total water use the variation is insignificant. In a later section water requirements for all plants are estimated to be 1.44 thousand gallons per thousand pounds of milk.

TABLE 39

ELECTRICITY CONSUMPTION RATES FOR REFRIGERATION FOR ALL PLANTS, BY MONTHS

\begin{tabular}{|c|c|c|c|}
\hline Month & $\begin{array}{c}\text { Electricity } \\
\text { consumption } \\
\text { rate }\end{array}$ & Month & $\begin{array}{c}\text { Electricity } \\
\text { consumption } \\
\text { rate }\end{array}$ \\
\hline & kwh/1,000 lbs milk & & $\mathrm{kwh} / 1,000 \mathrm{lbs}$ milk \\
\hline January ... & 2.92 & July......... & 3.61 \\
\hline February.. & 3.16 & August.. & 3.64 \\
\hline March...... & 3.40 & September.... & 4.85 \\
\hline April....... & 2.97 & October........ & 4.33 \\
\hline May...... & 3.12 & November................... & 3.49 \\
\hline June......... & 3.46 & December................ & 2.94 \\
\hline
\end{tabular}

Using the engineering formula for pumping operations, and specifying a total head of 200 feet, each thousand gallons of water requires $1.0 \mathrm{kwh}$ of electricity. Therefore, $1.44 \mathrm{kwh}$ per thousand pounds of milk are used by each plant for pumping water.

Table 40 illustrates the computed cost of electricity for Plant I. A similar procedure applied to each plant yields the electricity costs for each plant listed in table 41.

\section{Estimation of Refrigeration Rates}

Refrigeration is required to cool milk receipts prior to storage and to cool evaporated milk prior to storage or canning. During the period when processing takes place every day only the evening receipts need to be cooled. During the remainder of the year an average of approximately 85 per cent of the milk must be cooled. The milk is cooled to $40^{\circ} \mathrm{F}$. For example, the average maximum temperature specified for January is $54.3^{\circ} \mathrm{F}$. However, the milk may not have cooled to this level through contact with the air so a cooling range of $60^{\circ} \mathrm{F}$ to $40^{\circ} \mathrm{F}$ is used to estimate the tons of refrigeration needed per thousand pounds of milk. Approximately 850 pounds of milk are cooled per thousand pounds received. With an approximate specific heat of 0.94 and a $20^{\circ} \mathrm{F}$ temperature difference, 15,980 Btu's are required. One ton of refrigeration equals $12,000 \mathrm{Btu}$ 's, so 1.33 tons of refrigeration are required per thousand pounds of milk received in January.

Evaporated milk is cooled from approximately $140^{\circ} \mathrm{F}$ to $90^{\circ} \mathrm{F}$ by water

${ }^{55}$ This estimate is the result of empirical measurement by the equipment company under conditions specified here. 
TABLE 40

TOTAL ELECTRICITY CONSUMPTION RATE, TOTAL ELECTRICITY CONSUMED, AND ELEGTRICITY COST FOR PLANT I, BY MONTHS, 1953

\begin{tabular}{|c|c|c|c|c|}
\hline Month & $\begin{array}{c}\text { Total } \\
\text { electricity } \\
\text { consumption } \\
\text { rate }^{*}\end{array}$ & $\underset{\text { receipts } \dagger}{\text { Total milk }}$ & $\begin{array}{c}\text { Total } \\
\text { electricity } \\
\text { consumption }\end{array}$ & $\begin{array}{c}\text { Electricity } \\
\text { cost } \$\end{array}$ \\
\hline & $\begin{array}{c}k w h / 1,000 \\
\text { lbs milk }\end{array}$ & $1,000 \mathrm{lbs}$ & $1,000 \mathrm{kwh}$ & dollars \\
\hline $\operatorname{March} \ldots \ldots \ldots \ldots \ldots$ & 9.11 & 3,429 & 34.4 & 594 \\
\hline April.............. & 8.68 & 4,080 & 40.0 & 662 \\
\hline 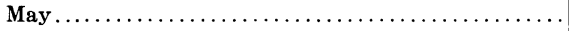 & 8.83 & 4,526 & 44.0 & 710 \\
\hline June............. & 9.17 & 4,320 & 43.6 & 705 \\
\hline July ............ & 9.32 & 4,217 & 43.2 & 700 \\
\hline November......... & 9.20 & 2,606 & 26.4 & 498 \\
\hline December............ & 8.65 & 2,572 & 24.5 & 476 \\
\hline 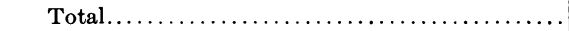 & & 41,043 & 416.5 & 7,177 \\
\hline
\end{tabular}

* Sum of individual rates listed in previous sections.

+ Table 5 .

\pm Column $1 \times$ Column $2 \times 1.10$. The estimate is increased by $10 \%$ to allow for lighting and other miscellaneous uses of electricity. This allowance adds $\$ 0.001$ to variable cost per case for Plant $\mathrm{I}$.

$\$$ Estimated from rate schedule given in Section II. Billing demand is $230 \mathrm{kw}$.

TABLE 41

TOTAL ELECTRICITY COST BY PLANTS, 1953

\begin{tabular}{|c|c|c|}
\hline Plant & $\begin{array}{c}\text { Billing } \\
\text { demand* }\end{array}$ & $\begin{array}{l}\text { Total annual } \\
\text { electricity cost } \dagger\end{array}$ \\
\hline & $k w$ & dollars \\
\hline$\ldots$ & 230 & 7,180 \\
\hline II $\ldots \ldots \ldots \ldots \ldots \ldots \ldots \ldots$ & 308 & 10,740 \\
\hline III $\ldots \ldots \ldots \ldots \ldots \ldots \ldots$ & 426 & 13,140 \\
\hline IV $\ldots \ldots \ldots \ldots \ldots \ldots \ldots \ldots$ & 506 & 15,510 \\
\hline $\mathrm{v} \ldots \ldots \ldots \ldots \ldots \ldots \ldots \ldots$ & 623 & 20,000 \\
\hline VI $\ldots \ldots \ldots \ldots \ldots \ldots \ldots \ldots$ & 729 & 25,330 \\
\hline
\end{tabular}

* Approximate peak demand.

† Estimated from rate schedule given in Section II. Figures are rounded.

and then from $90^{\circ} \mathrm{F}$ to $40^{\circ} \mathrm{F}$ by refrigeration. In January, 1,000 pounds of milk yield approximately 531 pounds of evaporated milk. Using a specific heat of 0.92 for evaporated milk and a cooling range of $50^{\circ} \mathrm{F}$, this quantity of evaporated milk requires 2.03 tons of refrigeration. Table 42 lists estimates of total refrigeration requirements by months for all plants.

\section{Estimation of Water Rates}

The principal use of water in the receiving room is to wash 10 -gallon cans. Farrall estimates 0.85 gallon of water per can..$^{56} \mathrm{~A}$ conservative estimate of one gallon per can is used here, or, with an average weight of milk per can

\footnotetext{
${ }^{50}$ Farrall, op. cit., p. 350.
} 
of 65 pounds, 15.4 gallons of water per thousand pounds of milk. In one of the equipment bulletins, an evaporator capable of processing 40.5 thousand pounds of milk per hour and using a vapor heater requires $205 \mathrm{gpm}$ of $55^{\circ} \mathrm{F}$ condensing water or $339 \mathrm{gpm}$ of $85^{\circ} \mathrm{F}$ condensing water. Since water temperature is here specified to be $70^{\circ} \mathrm{F}$, the average requirement is $272 \mathrm{gpm}$ or 403 gallons of condensing water per thousand pounds of milk.

Approximately 500 pounds of evaporated milk per thousand pounds of milk are cooled from $140^{\circ} \mathrm{F}$ to $90^{\circ} \mathrm{F}$. If the water increases in temperature

TABLE 42

RATES OF REFRIGERATION FOR COOLING MILK RECEIPTS AND EVAPORATED MILK FOR ALL PLANTS

\begin{tabular}{|c|c|c|c|c|c|c|}
\hline Month & $\begin{array}{l}\text { Milk } \\
\text { receipts } \\
\text { cooled }\end{array}$ & $\begin{array}{l}\text { Range } \\
\text { of cooling } \\
\text { required }\end{array}$ & $\begin{array}{l}\text { Refrigeration } \\
\text { requirement } \\
\text { per } 1,000 \mathrm{lbs} \\
\quad \text { of milk }\end{array}$ & $\begin{array}{l}\text { Evaporated } \\
\text { milk } \\
\text { per } 1,000 \mathrm{lbs} \\
\text { of milk }\end{array}$ & $\begin{array}{c}\text { Refrigeration } \\
\text { requirement } \\
\text { for cooling } \\
\text { evaporated } \\
\text { milk } \\
\text { equivalent }\end{array}$ & $\begin{array}{l}\text { Total } \\
\text { refrigeration } \\
\text { requirement } \\
\text { per } 1,000 \mathrm{lbs} \\
\quad \text { of milk }\end{array}$ \\
\hline & per cent & degrees $F$ & tons & $l b s$ & tons & tons \\
\hline February $\ldots \ldots \ldots \ldots \ldots \ldots$ & 85 & $65-40$ & 1.67 & 512 & 1.96 & 3.63 \\
\hline $\operatorname{March} \ldots \ldots \ldots \ldots \ldots \ldots$ & 85 & $70-40$ & 2.00 & 498 & 1.91 & 3.91 \\
\hline April........ & 50 & $80-40$ & 1.57 & 481 & 1.84 & 3.41 \\
\hline May ......... & 50 & $85-40$ & 1.76 & 478 & 1.83 & 3.59 \\
\hline June...... & 50 & $95-40$ & 2.15 & 478 & 1.83 & 3.98 \\
\hline October..... & 85 & $85-40$ & 3.00 & 516 & 1.98 & 4.98 \\
\hline November.. & 85 & $70-40$ & 2.00 & 526 & 2.01 & 4.01 \\
\hline December............... & 85 & $60-40$ & 1.33 & 534 & 2.05 & 3.38 \\
\hline
\end{tabular}

from $70^{\circ} \mathrm{F}$ to $80^{\circ} \mathrm{F}, 2,500$ pounds or 300 gallons of water are required. An estimate of 700 gallons per thousand pounds of milk is used for total water consumption in the evaporating stage.

The sterilizer equipment company reports a water consumption rate of $196 \mathrm{gpm}$ for a sterilization rate of $200 \mathrm{cpm}$. This is equivalent to 550 gallons per 1,000 pounds of milk.

A refrigeration company reports a rate of 3 gallons of $70^{\circ} \mathrm{F}$ cooling water per ton of refrigeration. This corresponds to an average of about 12 gallons of water per thousand pounds of milk.

Approximately 470 pounds of steam are used per thousand pounds of milk. This quantity of steam is equivalent to 56 gallons of water.

It is difficult to synthesize water requirements for cleaning. For the smallest plant, processing 146,000 pounds per 8-hour day, a rate of 15,000 gallons per day is specified. This amount is slightly more than is used in the evaporating stage during a two-hour period. For 304 operating days and for annual receipts of 41,043 thousand pounds of milk, this is equivalent to approximately 110 gallons of cleaning water per thousand pounds of milk.

Total water consumption is the sum of these estimates, 1.44 thousand gallons of water per thousand pounds of milk. This figure is used for all plants. 


\section{Estimation of Gas Consumption Rates and Gas Cost}

A manufacturer of automatic can washers reports steam requirements of 16 and 21 boiler hp for 8 and $13 \mathrm{cpm}$ can washers. These rates are equivalent to 1.1 and 0.9 pounds of steam per can. Farrall, on the other hand, reports a consumption rate of 1.84 pounds of steam per can for a $6.5 \mathrm{cpm}$ washer operated at capacity. ${ }^{57} \mathrm{~A}$ figure of 1.2 pounds of steam per can is used here. The resulting estimates are summarized in table 43 .

TABLE 43

STEAM CONSUMPTION RA'TES FOR RECEIVING STAGE BY PLANTS AND TIME PERIODS

\begin{tabular}{|c|c|c|c|c|c|}
\hline Plant & Time period & $\begin{array}{l}\text { Receiving } \\
\text { rate }\end{array}$ & Equipment used & $\underset{\begin{array}{c}\text { Steam } \\
\text { consumption } \\
\text { rate }\end{array}}{ }$ & $\underset{\substack{\text { Steam } \\
\text { consumption } \\
\text { rate }}}{.}$ \\
\hline & & lbs milk/hr & & $l b s / h r$ & $\begin{array}{c}l b s / 1,000 ~ l b s \\
\text { milk }\end{array}$ \\
\hline I.. & All year & 21,000 & $1-8 \mathrm{cpm}$ & 580 & 27.6 \\
\hline \multirow[t]{2}{*}{ II. } & Oct.-Feb. & 21,500 & $1-10 \mathrm{cpm}$ & 720 & 33.5 \\
\hline & Mar.-Sept. & 34,500 & $1-10 \mathrm{cpm}$ & 720 & 20.9 \\
\hline \multirow[t]{2}{*}{ III. } & Dec.-Jan. & 22,000 & $1-12 \mathrm{cpm}$ & 860 & 39.1 \\
\hline & Feb.-Nov. & 37,300 & $1-12 \mathrm{cpm}$ & 860 & 23.1 \\
\hline \multirow[t]{2}{*}{ IV. } & Sept.-Mar. & 34,500 & $1-10 \mathrm{cpm}$ & 720 & 20.9 \\
\hline & April-Aug. & 55,500 & $1-10+1-8 \mathrm{cpm}$ & 1,300 & 23.4 \\
\hline \multirow[t]{2}{*}{ V... } & Oct.-Feb. & 37,300 & $1-12 \mathrm{cpm}$ & 860 & 23.1 \\
\hline & Mar.-Sept. & 58,800 & $1-12$ and $1-10 \mathrm{cpm}$ & 1,580 & 26.9 \\
\hline \multirow[t]{2}{*}{ VI. } & Sept.-Mar. & 59,300 & $2-12 \mathrm{cpm}$ & 1,720 & 29.0 \\
\hline & April-May & 74,600 & $2-12 \mathrm{cpm}$ & 1,720 & 23.1 \\
\hline
\end{tabular}

Steam is used in the evaporating stage to preheat and evaporate milk. Assuming that the preheater using milk vapor at $170^{\circ} \mathrm{F}$ raises the temperature of the milk to $160^{\circ} \mathrm{F}$, steam is used to raise the temperature from $160^{\circ}$ $\mathrm{F}$ to $210^{\circ} \mathrm{F}$. At 85 per cent efficiency, 1,000 pounds of milk with a specific heat of 0.94 would require $55,200 \mathrm{Btu}$ or approximately 55 pounds of steam.

One evaporator company reports steam consumption for its line of evaporators at 275 pounds per thousand pounds of milk, making a total requirement of 330 pounds. A second company reports total consumption, including preheating of milk, from 327 to 329 pounds per thousand pounds of milk. The rate used here for all plants is 330 pounds of steam per thousand pounds of milk.

The sterilizer company reports a steam consumption rate of 9 pounds per case of evaporated milk or 103 pounds of steam per thousand pounds of milk.

Steam consumption for cleaning is estimated in the same manner as were the other cleaning utilities, the quantity of steam consumed during two hours operation of the evaporating stages. At a processing rate of 19,100 pounds of milk per hour, the evaporating stage of Plant I uses 12,600 pounds of

\footnotetext{
${ }^{57}$ Farrall, op. cit., p. 350.
} 
TAPLE 44

TOTAL STEAM CONSUMPTION RATES, TOTAL GAS CONSUMPTION RATES BY PLANTS AND TIME PERIODS

\begin{tabular}{|c|c|c|c|}
\hline Plant & Time period & $\begin{array}{c}\text { Steam } \\
\text { consumption } \\
\text { rate }\end{array}$ & $\underset{\text { consumption }}{\text { rate* }}$ \\
\hline & & $\begin{array}{l}\text { lbs steam } / 1,000 \\
\quad \text { lbs milk }\end{array}$ & Mcf/1,000 lbs milk \\
\hline I. & All year & 554 & 0.698 \\
\hline \multirow[t]{2}{*}{ II. } & Oct.-Feb. & 560 & 0.706 \\
\hline & Mar.-Sept. & 547 & 0.689 \\
\hline \multirow[t]{2}{*}{1.1} & Dec.-Jan. & 565 & 0.712 \\
\hline & Feb.-Nov. & 549 & 0.692 \\
\hline \multirow[t]{2}{*}{ IV } & Sept.-Mar. & 547 & 0.689 \\
\hline & April-Aug. & 550 & 0.693 \\
\hline \multirow[t]{2}{*}{ V. } & Oct.-Feb. & 549 & 0.692 \\
\hline & Mar.-Sept. & 553 & 0.697 \\
\hline \multirow[t]{2}{*}{ VI. } & Sept.-Mar. & 555 & 0.699 \\
\hline & April-May & 549 & 0.692 \\
\hline
\end{tabular}

* Conversion rate of $1.26 \mathrm{Mcf}$ per $1,000 \mathrm{lbs}$ of steam.

TABLE 45

ANNUAL GAS COST BY PLANTS

\begin{tabular}{|c|c|}
\hline Plant & $\begin{array}{c}\text { Annual gas cost } \\
1953\end{array}$ \\
\hline & dollars \\
\hline I. & 11,470 \\
\hline II. & 18,120 \\
\hline III. & 22,100 \\
\hline IV ......... & 26,570 \\
\hline$\ldots \ldots \ldots \ldots \ldots \ldots \ldots$ & 32,600 \\
\hline 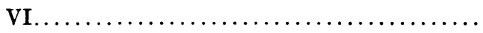 & 42,820 \\
\hline
\end{tabular}

steam in two hours. Total annual steam for cleaning for 304 days' operation is $3,830,400$ pounds or 93.3 pounds of steam per 1,000 pounds of milk. ${ }^{58}$

Table 44 summarizes total steam consumption rates for each plant. Gas consumption rates are derived from these by using a conversion rate of 1.26 Mef per thousand pounds of steam. This rate corresponds to an efficiency of 70 per cent in the production of steam, an efficiency reported by the boiler manufacturer in a technical bulletin.

Total gas consumption per month for a given plant is obtained by multiplying total milk receipts per month by the appropriate gas consumption rate and then by increasing the result by 10 per cent to allow for other minor uses of gas and/or inefficiencies in operation. The corresponding quantities of gas are valued by the rate schedule given in Section II and summed to obtain annual cost of gas. Table 45 lists annual gas cost for each plant.

\footnotetext{
${ }^{58} 3,830,400 \mathrm{lbs}$. of steam

41,043 thousand lbs. of milk
} 


\section{Section VIII \\ ESTIMATION OF LONG AND SHORT RUN COST FUNCTIONS}

Annual processing costs have been estimated for 10 cost categories for each of the six plants. ${ }^{59}$ For ease in interpretation these annual costs are converted to average costs per case. The results are summarized in table 46 . For the specified plants, operating under the conditions enumerated in earlier sections, average processing cost per case of evaporated milk de-

TABLE 46

FIXED AND VARIABLE COSTS PER CASE, BY COST CATEGORY, 1953

\begin{tabular}{|c|c|c|c|c|c|c|}
\hline Item & Plant I & Plant II & Plant III & Plant IV & Plant V & Plant VI \\
\hline \multirow[t]{2}{*}{ Output 1,000 cases.. } & 468.6 & 760.6 & 937.2 & $1,142.6$ & $1,405.8$ & $1,874.4$ \\
\hline & \multicolumn{6}{|c|}{ cents per case } \\
\hline Annual equipment cost. & 9.20 & 7.81 & 7.32 & 7.51 & 7.03 & 6.78 \\
\hline Annual building cost... & 1.25 & 0.94 & 0.86 & 0.81 & 0.76 & 0.69 \\
\hline Fixed labor and management cost. & 13.08 & 8.80 & 8.18 & 7.50 & 6.82 & 5.75 \\
\hline Office supply cost* ${ }^{*} \ldots \ldots \ldots \ldots \ldots$ & 0.67 & 0.67 & 0.67 & 0.67 & 0.67 & 0.67 \\
\hline Laboratory supply cost*. & 0.35 & 0.35 & 0.35 & 0.35 & 0.35 & 0.35 \\
\hline Average fixed cost... & 24.55 & 18.57 & 17.38 & 16.84 & 15.63 & 14.24 \\
\hline Variable labor cost..... & 16.13 & 13.04 & 11.97 & 11.75 & 11.13 & 9.94 \\
\hline Cleaning supply cost* $\ldots \ldots \ldots \ldots \ldots \ldots$ & 1.07 & 1.07 & 1.07 & 1.07 & 1.07 & 1.07 \\
\hline Machinery rental cost................. & 2.50 & 2.50 & 2.50 & 2.50 & 2.00 & 2.00 \\
\hline Electricity cost................... & 1.53 & 1.41 & 1.40 & 1.36 & 1.42 & 1.35 \\
\hline Gas cost $\ldots \ldots \ldots \ldots \ldots \ldots \ldots \ldots \ldots \ldots$ & 2.45 & 2.38 & 2.36 & 2.33 & 2.32 & 2.28 \\
\hline A verage variable cost. & 23.68 & 20.40 & 19.30 & 19.01 & 17.94 & 16.64 \\
\hline Average total cost.... & 48.23 & 38.97 & 36.68 & 35.85 & 33.57 & 30.88 \\
\hline
\end{tabular}

* Data not available to estimate economies of scale, if any.

creases from 48.2 cents for Plant I to 30.9 cents for Plant VI, a decrease of about 36 per cent. The principal differences occur in the labor and management categories. The cost of fixed labor and management for Plant VI is 7.3 cents per case less than for Plant I, while the cost of variable labor is 6.2 cents less. Another major difference is that of 3.0 cents per case for the cost of equipment and building. These categories account for 16.5 cents of the total difference of 17.3 cents per case. Minor savings occur in machinery rental and electricity and gas cost.

\section{Long Run Cost Functions}

These estimates are conveniently summarized in a long run cost function under the assumption that annual total costs of other plants with intermediate capacities will behave in the same manner as those for the specific plants already analyzed.

\footnotetext{
${ }^{59}$ Packaging costs are excluded.
} 
For a variety of reasons, all cost categories exhibit a close linear relationship with annual output. For example, the correlation between annual equipment cost and annual output is 0.9986 . This high correlation indicates that a straight line graph will closely approximate the six specific estimates already obtained and will serve to indicate annual equipment cost for plants having intermediate capacities. ${ }^{00}$ The equation obtained by the method of least squares is:

$$
\mathrm{EC}=14.120+0.0604 \mathrm{Q}
$$

where EC is estimated annual equipment cost measured in thousands of dollars and $Q$ is annual output measured in thousands of cases of evaporated

TABLE 47

REGRESSION EQUATIONS FOR ESTIMATING ANNUAL COSTS BY COST CATEGORIES, 1953

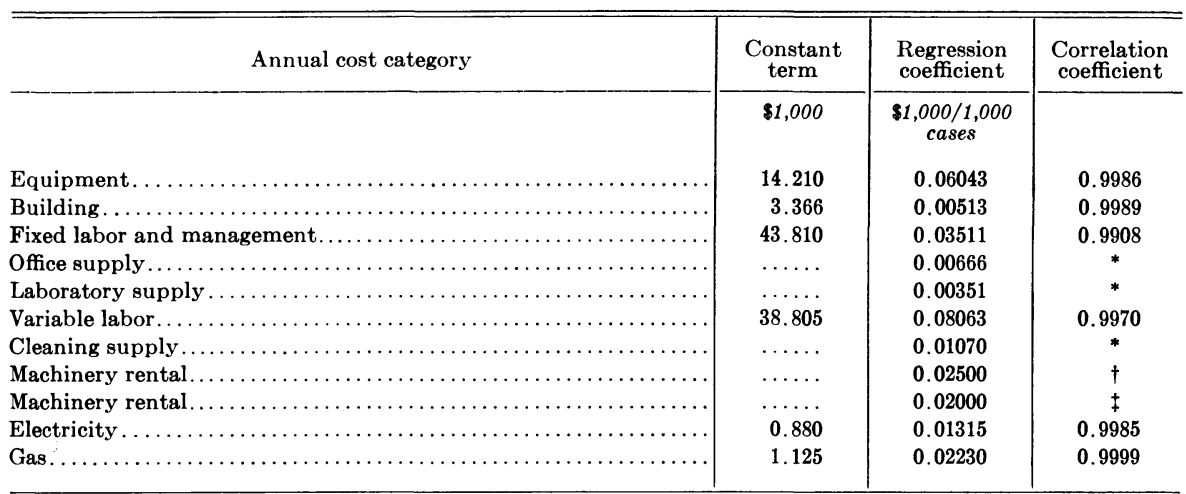

* Estimates were made for the cost per case for Plant I and then used for all plants.

$\dagger$ This rate applies to plants having one or two sterilizers, i.e., for plants having annual output less than or equal to 1,143 thousand cases per year.

$\ddagger$ This rate applies to plants having more than two sterilizers, i.e., for annual output greater than 1,143 thousand cases.

milk. Thus a plant with an annual capacity, as here defined, of one million cases of evaporated milk would have an estimated annual equipment cost of $(14.210)+(0.0604)(1000)=74.6$ thousands of dollars.

The results of similar analyses are found in table 47 . These equations are added to obtain total annual cost as a function of annual output. Because of the discontinuity in the machinery rental rate, one equation is needed for annual output less than or equal to 1,143 thousand cases per year and another for outputs greater than this quantity. The two equations are:

$$
\begin{gathered}
\mathrm{TC}=102.196+0.2626 \mathrm{Q}, \mathrm{Q} \leq 1143 \\
\text { and } \\
\mathrm{TC}=102.196+0.2576 \mathrm{Q}, \mathrm{Q}>1143,
\end{gathered}
$$

where TC is estimated total annual cost measured in thousands of dollars and $Q$ is annual output measured in thousands of cases of evaporated milk.

\footnotetext{
${ }^{60}$ Even when there is a limited number of alternative sizes of equipment for particular stages, the aggregation of step functions is likely to be closely approximated by a smooth function.
} 
These total cost functions are converted to average cost functions by dividing both sides of the equations by $\mathrm{Q}$ to obtain:

$$
\begin{aligned}
& \mathrm{AC}=\frac{102.196}{\mathrm{Q}}+0.2626 \\
& \mathrm{And} \\
& \mathrm{AC}=\frac{102.196}{\mathrm{Q}}+0.2576
\end{aligned}
$$

where $\mathrm{AC}$ is average processing cost per case (see tables 46 and 47 ).

The degree to which these equations approximate the specific estimates already obtained is illustrated in table 48 . The average difference between the previous estimates of annual total processing cost and the approxima-

TABLE 48

A COMPARISON BETWEEN SPECIFIC COST ESTIMATES AND APPROXIMATIONS DERIVED FROM LONG RUN COST FUNCTIONS,

\begin{tabular}{|c|c|c|c|c|c|c|}
\hline Item & Plant I & Plant II & Plant III & Plant IV & Plant V & Plant VI \\
\hline \multirow[t]{2}{*}{ Output 1,000 cases..... } & 468.6 & 760.6 & 937.2 & $1,142.6$ & $1,405.8$ & $1,874.4$ \\
\hline & \multicolumn{6}{|c|}{ Annual total processing cost, thousands of dollars } \\
\hline Previous estimate.. & 226.0 & 296.5 & 343.7 & 409.5 & 472.0 & 578.9 \\
\hline Cost function..... & 225.3 & 301.9 & 348.3 & 402.2 & 465.1 & 585.0 \\
\hline Difference....... & 0.7 & -5.4 & $\begin{array}{c}-4.6 \\
\text { (per cent) }\end{array}$ & 7.3 & 6.9 & -6.1 \\
\hline \multirow[t]{2}{*}{ Per cent difference..... } & 0.3 & -1.8 & -1.3 & 1.8 & 1.5 & -1.1 \\
\hline & \multicolumn{6}{|c|}{ Average processing cost per case, dollars } \\
\hline Previous estimate...... & 0.4823 & 0.3897 & 0.3668 & 0.3585 & 0.3357 & 0.3088 \\
\hline Cost function. ..... & 0.4807 & 0.3970 & 0.3716 & 0.3520 & 0.3303 & 0.3121 \\
\hline Difference............. & 0.0016 & -0.0073 & -0.0048 & 0.0065 & 0.0054 & 0.0033 \\
\hline
\end{tabular}
BY PLANTS, 1953

tions based on the cost functions is 5.2 thousand dollars and 1.3 per cent. The average difference in average cost per case is $\$ 0.0048$ per case. These deviations are small relative to the probable margin of error in the original estimates. Consequently, the long run cost functions conveniently summarize the preceding analysis of the six specific plants and at the same time indicate total and average costs for plants of intermediate capacity.

\section{Short Run Cost Functions}

The primary objective of this study is to measure economies of scale for evaporated milk plants. For this objective, it is unnecessary to make a distinction between fixed and variable cost categories. With such a dichotomy, however, short run cost functions can be estimated from the same data. However, classification of costs as fixed or variable is meaningful only in specified ranges of output variation. If annual milk receipts exceed those specified in Section II, overtime payments will be required during the flush season. Also, receiving rooms may need to be redesigned so that the increased 
daily receipts can be handled in a reasonable time. If annual milk receipts fall far below those specified, certain of the fixed costs might become variable. Consequently, the short run cost functions below are not valid for outputs in excess of annual plant capacity as here defined and tend to overestimate costs for outputs far below capacity. Such overestimation is partially offset by the increase in electricity and gas cost rates associated with reduced consumption.

Total annual processing cost for a particular plant is estimated by adding the estimate of total annual fixed cost to the product of total annual output

TABLE 49

SHORT RUN COST FUNCTIONS BY PLANTS, 1953

\begin{tabular}{|c|c|c|c|}
\hline Plant & $\begin{array}{l}\text { Annual fixed } \\
\text { cost }\end{array}$ & $\begin{array}{l}\text { Variable cost } \\
\text { per case }\end{array}$ & $\begin{array}{c}\text { Plant } \\
\text { capacity }\end{array}$ \\
\hline & $\$ 1,000$ & dollars & 1,000 cases \\
\hline I. & 115.0 & 0.2369 & 468.6 \\
\hline II. & 141.3 & 0.2040 & 760.7 \\
\hline III. & 162.8 & 0.1930 & 937.2 \\
\hline IV. . & 192.4 & 0.1900 & $1,142.6$ \\
\hline V. & 219.8 & 0.1794 & $1,405.8$ \\
\hline VI $\ldots \ldots \ldots \ldots \ldots \ldots \ldots \ldots \ldots \ldots \ldots \ldots$ & 266.8 & 0.1665 & $1,874.4$ \\
\hline
\end{tabular}

and estimated variable processing cost per case. For example, the short run cost function for Plant $I$ is:

$$
\mathrm{TC}_{\mathrm{I}}=115.0+0.2369 \mathrm{Q}_{\mathrm{I}},
$$

where $\mathrm{TC}_{\mathrm{I}}$ is total annual processing cost for Plant I measured in thousands of dollars and $Q_{\text {I }}$ is annual output for Plant I measured in thousands of cases of evaporated milk.

Short run cost functions for each plant are listed in table 49. Note that the larger plants have larger fixed costs but smaller variable costs. In general, however, it is more economical to use a smaller plant operating at capacity than it is to operate a larger plant at less than capacity to process the same quantity. For example, Plant II has an annual fixed cost that is $\$ 26,300$ larger than Plant I. If Plant II were used to produce 468,600 cases, the capacity of Plant I, annual variable processing cost would be reduced only $\$ 15,400$.

These short run total processing cost functions are converted to average functions by dividing both sides of the equations by the corresponding quantity of output. For example, the short run average function for Plant I is:

$$
\mathrm{APC}_{\mathrm{I}}=\frac{115.0}{\mathrm{Q}_{\mathrm{I}}}+0.2369
$$

where $\mathrm{APC}_{\mathrm{I}}$ is average processing cost per case for Plant I. Thus, if Plant I were to process only 400,000 cases of evaporated milk, average processing cost per case would be estimated at 52 cents per case rather than 48 cents per case at capacity output. Short run average cost functions are illustrated in table 49. 


\section{Section IX}

\section{CONCLUSIONS}

The long run cost functions derived in preceding sections show the net covariation of two variables, unit processing cost and output, where the scale of plant is adjusted to each alternative output rate but all other potential cost determinants such as technology and operating conditions are not allowed to vary. Suceeding analyses could break from this two-dimensional pattern and investigate the effect on processing cost of variation in one or more of the basic specifications. For example, the various plants could be redesigned to use triple-effect rather than double-effect evaporators. Alternative refrigeration systems could be provided. Each plant could be equipped with receiving stages having twice the present capacity, resulting in doubling the potential output range through two-shift operation of the rest of the plant.

While the detailed specifications of Sections II and III may seem to narrow the range of potential application of the results of this study, such a conclusion does not necessarily follow. In the first place, the specifications and analysis are sufficiently detailed to enable interested persons not only to alter the specifications but also to estimate the effect of such alteration on unit cost. In the second place, many changes in specifications would be likely to result in only minor modifications of the cost functions or at least would affect primarily the level of cost while preserving cost differences between plants.

Assuming the long run cost functions are valid, how can they be used? In combination with studies of procurement and site costs, they can be used as an aid in selecting the size and location of a new plant to minimize the sum of procurement and processing costs. This question does not seem to be a particularly pertinent one in California in the near future. However, it is likely to be of interest in those areas of the Northwest which are being developed for dairy production.

Secondly, they can be used to give some indication of the saving in processing cost associated with the reorganization of part or all of the evaporated milk industry in the Western Region. Most of the California plants are located in an area which also supplies large quantities of fluid milk to the San Francisco Bay area. Declining per-capita milk production and/or declining per-capita demand for evaporated milk may make existing plant locations and sizes quite inefficient. Even in 1951, three plants produced less than 60 per cent of their largest annual output since 1941; two plants produced only about 75 per cent of their largest annual output; while the remainder almost equalled or exceeded their largest annual output. No attempt was made to relate the largest annual output to the technical definition of capacity used here, but the presumption remains that unit costs in the first five plants are substantially higher than they would have been under capacity utilization.

All but two of the 11 California plants have an eight-hour capacity intermediate between Plants I and II. One is larger and one is smaller. In the 
longer run, then, processing costs for evaporated milk in California could be substantially reduced if existing plants were replaced by a smaller number having capacities ranging up to three times as large as most of the current plants. The saving in processing costs associated with such a change might be partially offset by increases in the collection costs necessary to achieve the higher volume of receipts. Disregarding the potential increase in collection costs, the results of the analysis of the preceding sections indicate that, if three plants similar to Plant I were replaced by one plant similar to Plant V, all operating at 100 per cent capacity, exactly the same annual output would be achieved with total processing costs reduced by approximately $\$ 201,000$. If this saving were realized, the total investment required for such a plant would be equivalent to this saving accrued over a period of less than four years.

While less precise than the long run cost functions, the short run functions can be used to estimate the effect of excess capacity and to analyze the effect of alternative patterns of seasonal variation in milk supply.

Perhaps a word of caution should be inserted at this point. It has already been emphasized that this study is not aimed at measuring industry-wide average processing cost per case actually incurred by California plants during some historical period. Consequently, it cannot be used as a basis for price control or as a basis for determining "fair price," so long as these concepts are tied to historical averages or to "bulk-line" cost functions based primarily on accounting data. The analysis might prove useful, on the other hand, for any public program aimed at improving economic efficiency in the evaporated milk industry.

The final section consists of a brief discussion of the methodology used in the preceding analysis. Detailed accounting data from a majority of California plants were not available. Nine out of 11 California plants are of approximately the same capacity. Insufficient personnel were available to use the detailed industrial engineering techniques recently employed with excellent results in studies on cost and efficiency in California fruit packing houses.

It is not clear, however, that any other method would have been chosen if, in fact, other alternatives were possible. The principal advantages of the method used are:

1. Cost estimates are prepared for a set of specific plants which are essentially similar in all cost-determining characteristics except scale of plant. Thus the effect of scale changes is not obscured by other differences which are usually present in a set of existing plants.

2. The method is essentially forward-looking. If the problem is one of estimating the unit processing costs associated with plants of alternative capacities, the construction of which is planned, then the type and efficiency of equipment which need to be considered is that which is currently available, not that which was manufactured and installed sometime during the past 10 or 20 years.

3 . It is possible to adjust the cost estimates in response to varia- 
tion in any one of the cost determinants. In other words, the relationship between the assumed operating conditions and technology on the one hand and the cost estimates on the other are specific. Other procedures, such as the statistical handling of accounting data, generally are not capable of identifying the effect of changes in the many cost-determining variables.

The results obtained, however, are strongly conditioned by the specifications of operating conditions and technology, and by the data available from which to make estimates. Greater confidence in the applicability of the results would have resulted if it had been possible to obtain more empirical data from the California plants. Specifically, accounting information as to management costs, insurance, repair and maintenance, tax and depreciation rates, as well as certain general supply costs, would have been helpful in determining their range of variation and median values.

Undoubtedly, more refined results would have been possible if some of the industrial engineering measurement techniques had been applied to specific operations in each plant. These procedures would have been necessary if the major objective were to improve labor efficiency or to suggest the most efficient stage technology for each scale of operation. For the more limited objective here, it is a moot question whether the increased precision would have justified the increased research input. So many of the jobs in evaporated milk plants are machine-paced and supervisory rather than manual that more refined techniques might not significantly improve the precision of labor estimates. 


\section{BIBLIOGRAPHY}

BREMS, HANS

1952. A discontinuous cost function. Amer. Econ. Rev. 42:577-86.

BRESSLER, R. G.

1945. Research determination of economies of scale. Jour. Farm Econ. 27:526-39.

1950. Efficiency in the production of marketing services. University of Chicago Social Science Research Council Project in Agricultural Economics, Economic Efficiency Series Paper No. 6.

1952. City milk distribution. Cambridge, Harvard University Press.

1952. Efficiency in fruit marketing: marketing costs for deciduous fruits. Berkeley, Giannini Foundation Agricultural Economics Mimeographed Report 127.

California Crop and Livestock Reporting Service. Dairy information bulletin, Sacramento. (Monthly issues.)

California Crop and Livestock Reporting Service. Manufactured dairy products, milk production, utilization and prices. Sacramento. (Annual issues.)

Carlson, Sune

1939. A study on the pure theory of production. London, P. S. King and Son, Ltd.

Chenery, Hollis B.

1953. Process and production functions from engineering data. In Studies in the Structure of the American Economy, by Wassily Leontief and others. PP. 297-325.

Clark, J. MaUrice

1923. Studies in the economics of overhead costs. Chicago, University of Chicago Press.

Committee on Price Determination

1943. Cost behavior and price policy. New York, National Bureau of Economic Research.

Croxton, Frederick E., and DudLey J. Cowden

1939. Applied general statistics. New York, Prentice-Hall, Inc.

DORFMAN, ROBERT

1951. Application of linear programming to the theory of the firm. Berkeley, University of California Press, 1951.

Dubov, IRving

1954. The evaporated milk industry in the Western Region. (Doctoral dissertation, University of California, Berkeley.)

Farrall, ARThur W.

1953. Dairy engineering. $2 d$ ed. New York, John Wiley and Son, Inc.

French, BenJamin Carver

1953. Economic efficiency in California pear packing plants. (Doctoral dissertation, University of California, Berkeley.)

French, B. C., L. L. SAmmet, and R. G. Bressler

1956. Economic efficiency in plant operations with special reference to the marketing of California pears. Hilgardia 24(19):543-721.

French, Charles E., G. B. Wood, and V. C. ManharT

1952. Labor utilization in receiving rooms of Indiana milk plants. Purdue Agr. Exp. Sta. Bull. 576.

Grocery Manufacturers of America

1953. Evaporated milk, a study of the spread between the price of raw farm products and the price paid at the store by the consumer. New York, September. (Reprinted from the National Grange Monthly.)

Hall, CARL V.

1953. Up receiving-room efficiency. Food Eng. 25(4):66ff.

Harrington, A. H., and Wendell Calmoun

1952. The dairy balance of the Pacific slope. Washington Agr. Exp. Sta. Cir. 191. 
Hart, Albert G.

1942. Risk, uncertainty, and the unprofitability of compounding probabilities. Studies in Mathematical Economics and Econometrics. Chicago, University of Chicago Press.

Hassler, JAMEs B.

1953. Pricing efficiency in the manufactured dairy products industry. Hilgardia 22 (8) :235-334.

Hedges, Trimble R., and Warren R. Bailey

1952. Appraisal of California agricultural productive capacity attainable in 1955 . Berkeley, Giannini Foundation Agricultural Economics, Mimeographed Report 130.

HUNZIKER, OTTO FREDERICK

1946. Condensed milk and milk powder. 6th ed. La Grange, Illinois. Otto Frederick Hunziker.

JACK, E. L., E. B. Roessler, F. H. ABBotT, and A. W. IRWin

1951. Relationship of solids-not-fat to fat in California milk. California Agr. Exp. Sta. Bul. 726.

Joint Council 38 and Milk Products Manufacturers Associatton of California Wage seale and agreement. January 1, 1953 and January 1, 1956.

Lutz, Friedrich, and Vera Lutz

1951. The theory of investment of the firm. Princeton, Princeton University Press.

Mojonnier, Timothy, and Hugh Charles Troy

1925. The technical control of dairy products. $2 \mathrm{~d}$ ed. Chicago, Mojonnier Bros. Company.

Nelson, Glen T.

1954. Input-output relationships in specialized butter-powder and cheese plants. Oregon Agr. Exp. Sta. Tech. Bul. 32.

Page, Clayton M., and SCOTT A. WALker

1953. Building designs for dairy processing plants. Idaho Agr. Exp. Sta. Bul. 297.

Roadhouse, Chester Linwood, and James Lloyd Henderson

1950. The market-milk industry، $2 d$ ed. New York, MeGraw-Hill Book Company, Ine.

Rowe, GoRDoN A.

1952. Economics of cheese manufacturing in Tillamook County, Oregon. Oregon Agr. Exp. Sta. Bul. 529.

SAMMET, L. L.

1953. In-plant transportation costs as related to materials handling methods-apple and pear packing. Berkeley, Giannini Foundation Agricultural Economics Mimeographed Report 142.

SAMmet, L. L., and I. F. Davis

1952. Building and equipment costs, apple and pear packing. Berkeley, Giannini Foundation Agricultural Economics Mimeographed Report 141.

Tinley, J. M., and G. W. Parks

1953. Consolidation of citrus packing houses in the Ontario-Cucamonga area. Berkeley, Giannini Foundation Agricultural Economies Mimeographed Report 154.

TYLER, CHAPLIN

1948. Chemical engineering economies. 3d ed. New York, MeGraw-Hill Book Company, Inc.

U. S. Agricultural Marketing Service Production of manufactured dairy products. Wash., D. C. (Annual issues.)

U. S. Bureau of AGricultural Economics Dry, condensed and evaporated milk report. Wash., D. C. (Monthly issues.)

U. S. Bureau of The Census

Current population reports. Wash., D. C. Series P-25, Nos. 56, 72, and 84. 


\section{U. S. Bureau Internal Revenue}

1948. Bulletin "F", income tax depreciation and obsolescence, estimated useful lives and depreciation rates. (Rev. January, 1942.) Wash., D. C.

U. S. BuREAU REClaMation

1945. Agricultural processing industries, Columbia Basin Joint Investigations, Problem 24. Wash., D. C., U. S. Govt. Print. Off.

\section{U. S. Production and Marketing Administration}

1946. Milk products, costs, prices and products of war food purchases. Wash., D. C.

U. S. WEATHER BUREAU

1934. Summary of the climatological data for the U. S. by sections. Section 15-18, California, Washington.

Walker, SCOTT H., Homer J. Preston, and Glen T. Nelson

1953. An economic analysis of butter-nonfat dry milk plants. Idaho Agr. Exp. Sta. Res. Bul. 20. 
APPENDIX A

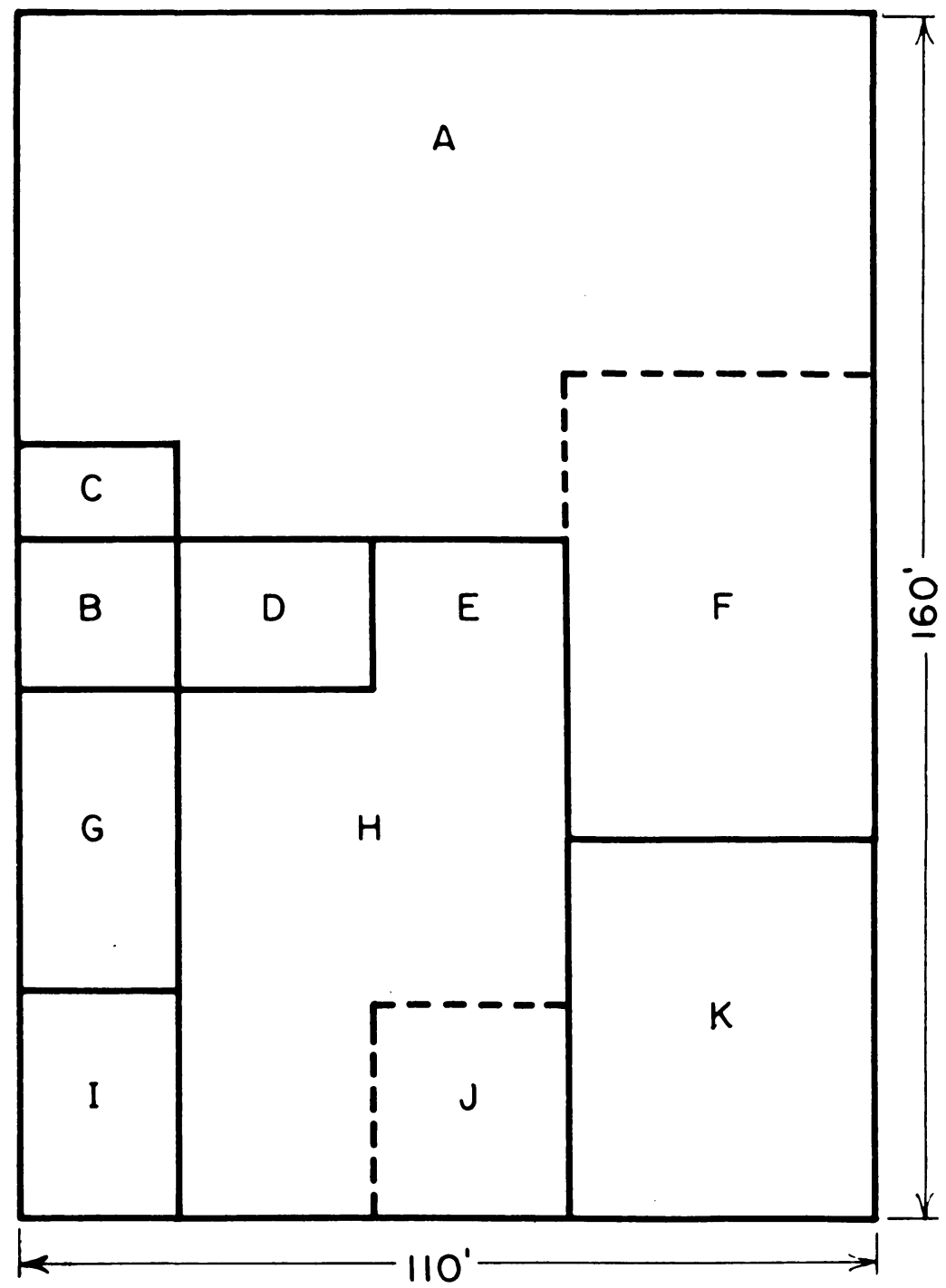

Fig. A-1. Floor plan for Plant II. 


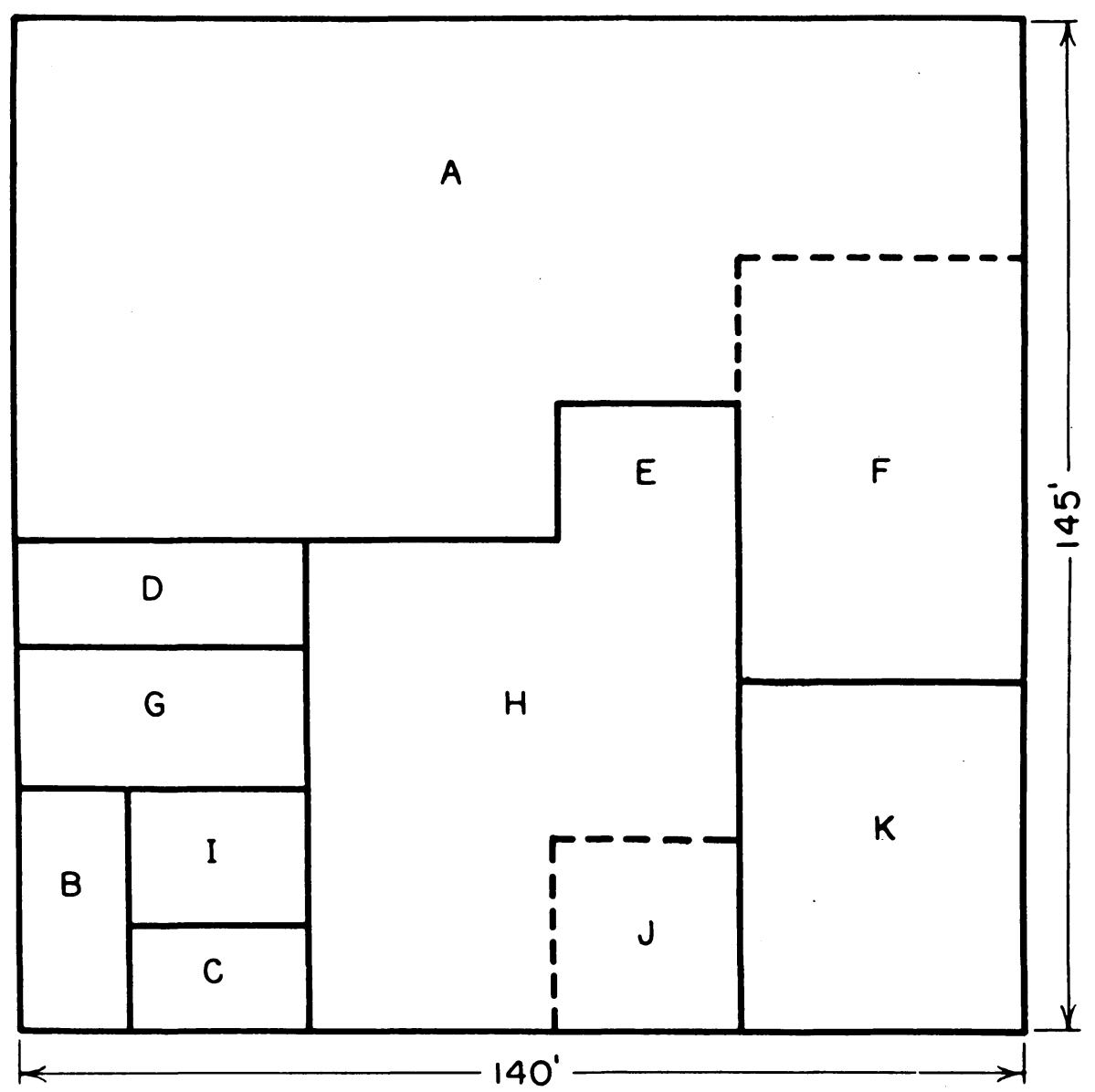

Fig. A-2. Floor plan for Plant III. 


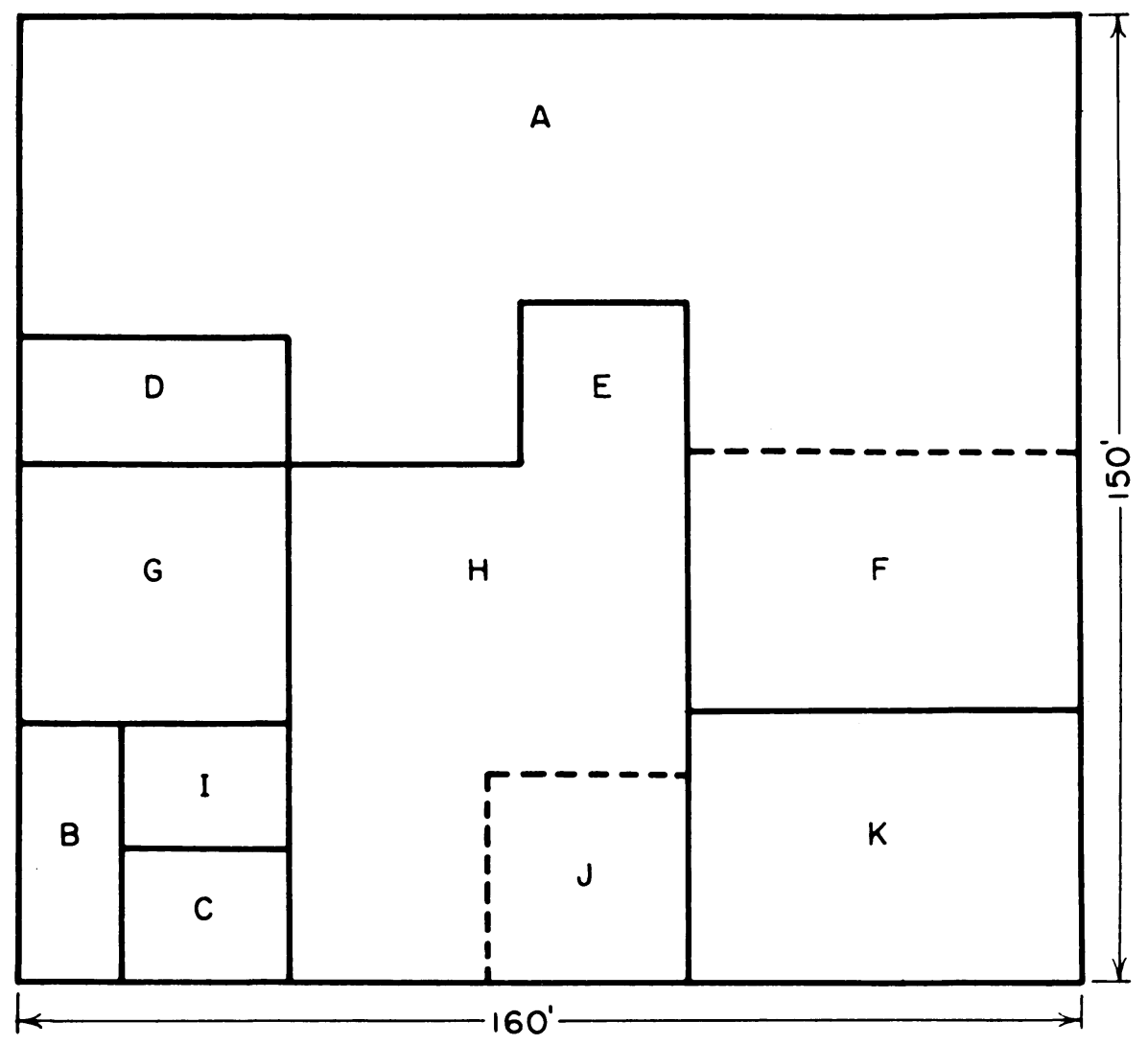

Fig. A-3. Floor plan for Plant IV. 


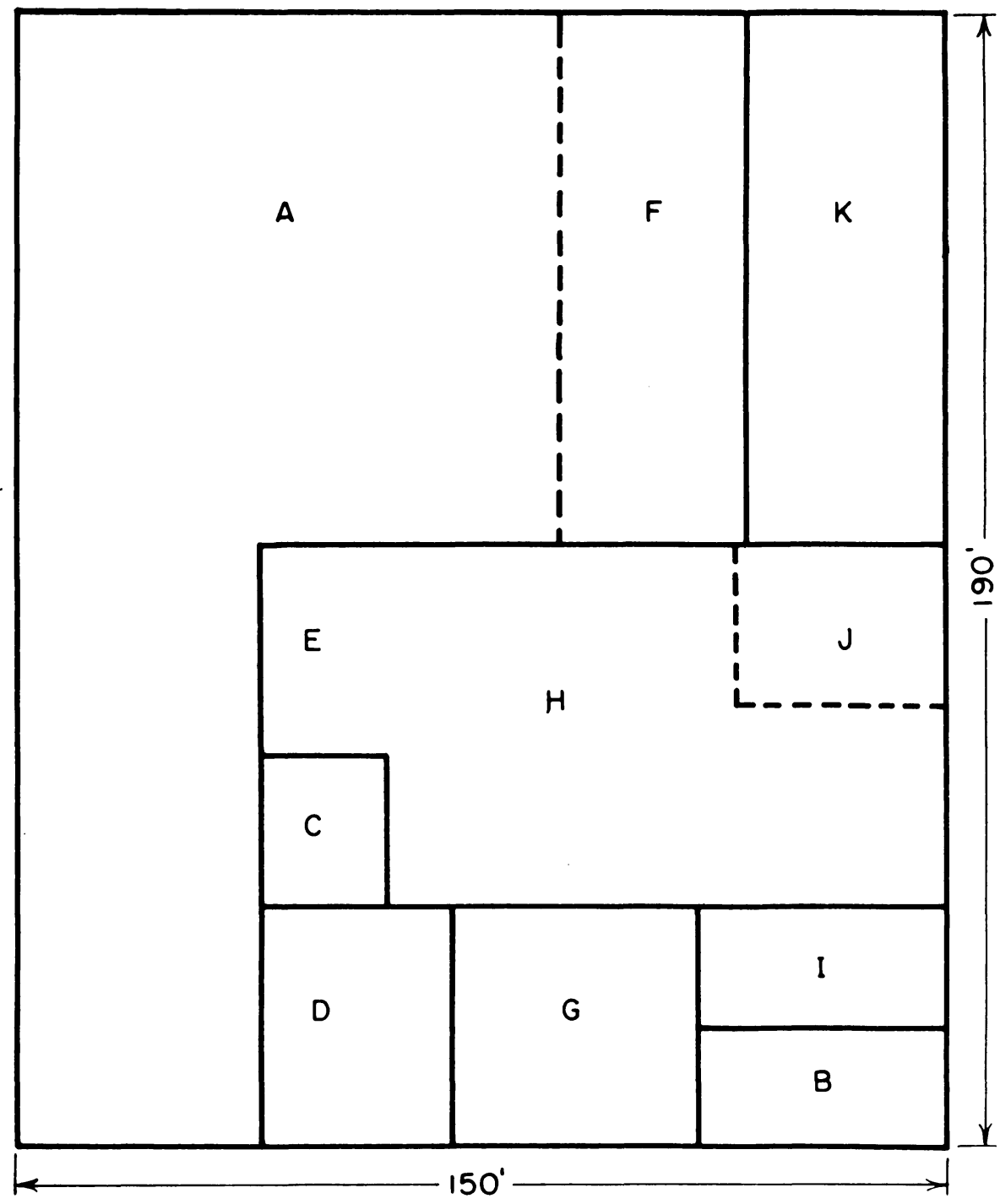

Fig. A-4. Floor plan for Plant V. 


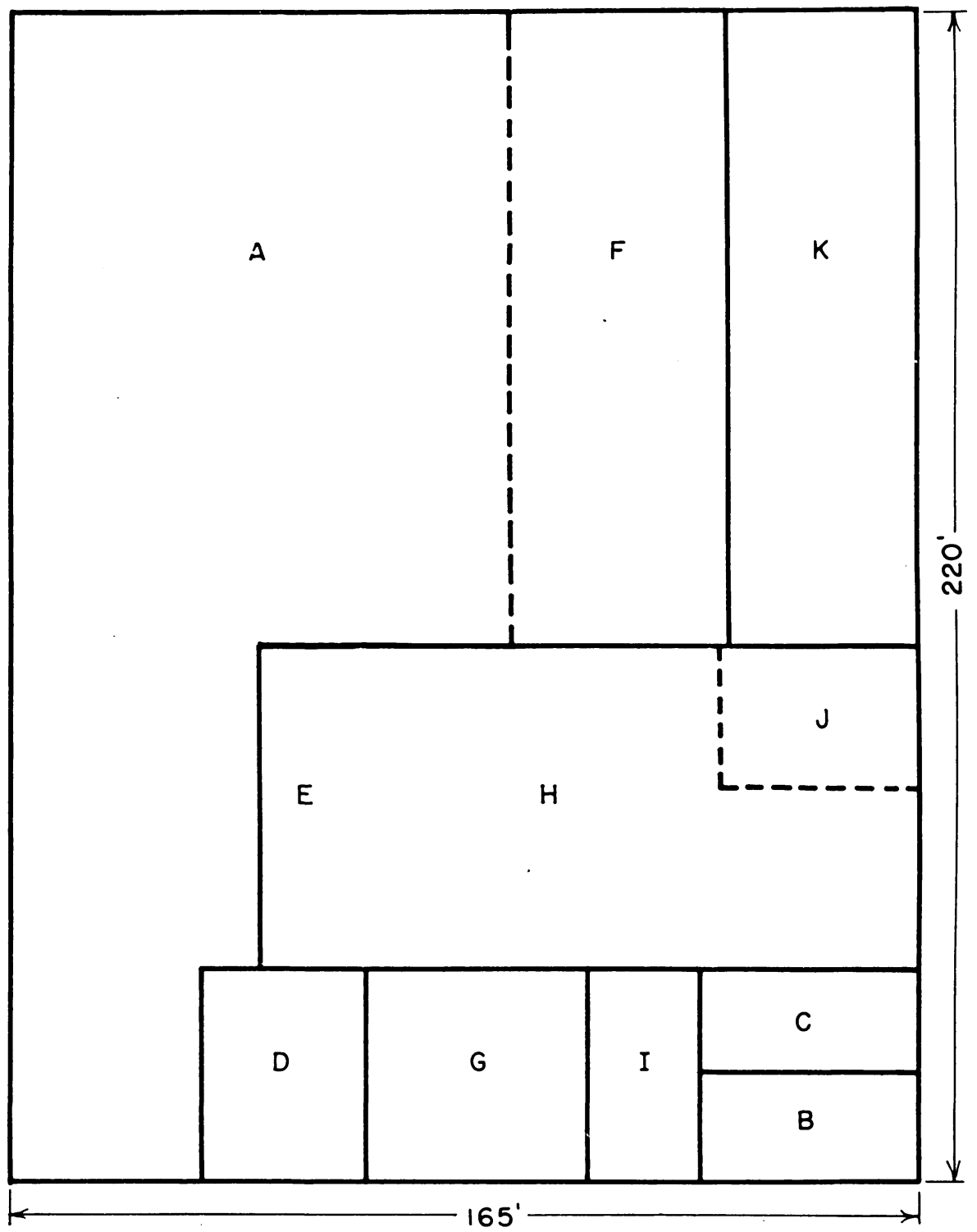

Fig. A-5. Floor plan for Plant VI. 

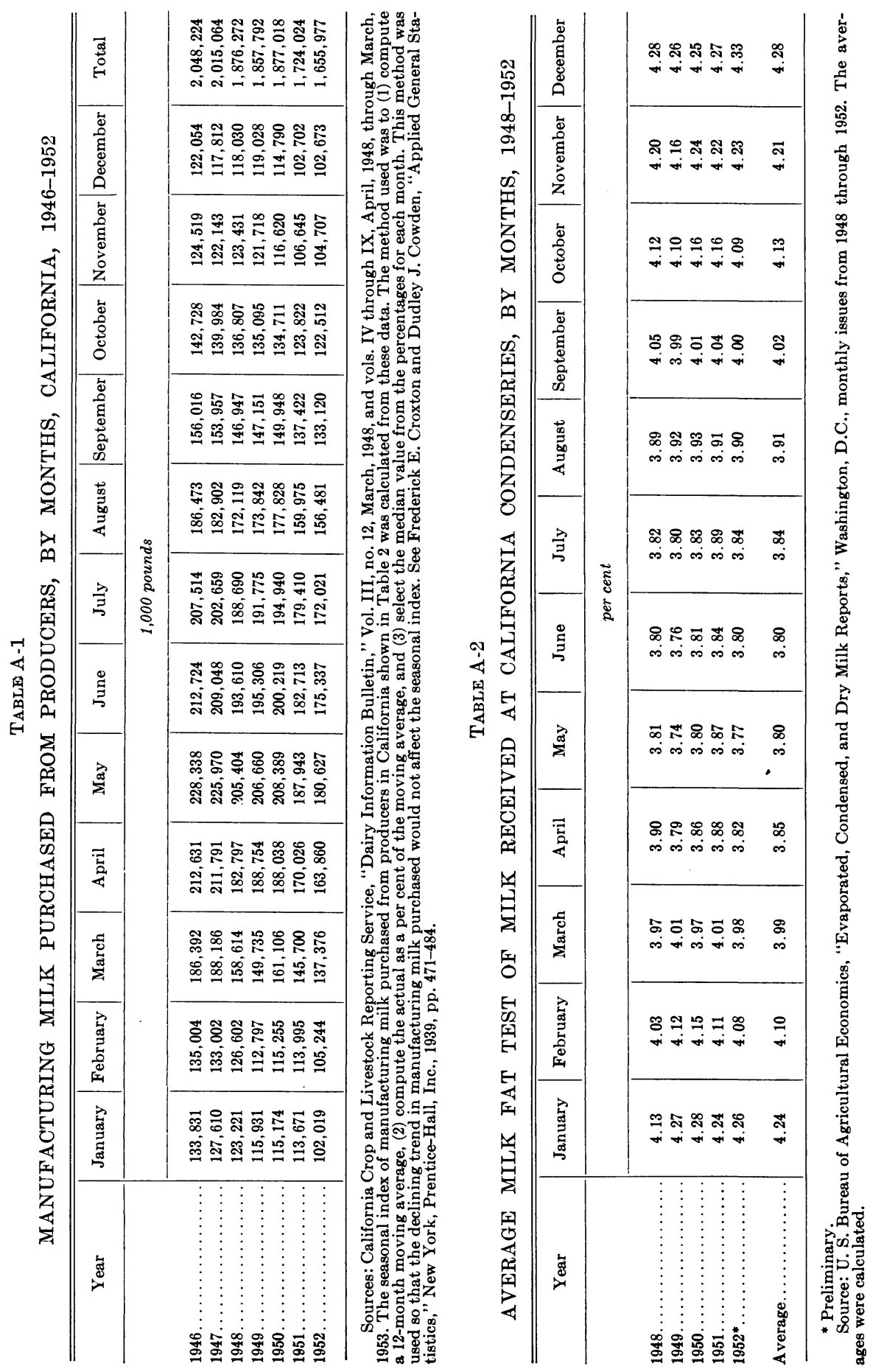
TABLE A-3

EQUIPMENT LIST, INVESTMENT, AND ANNUAL DEPRECIATION FOR RECEIVING STAGE, PLANT II

\begin{tabular}{|c|c|c|c|c|c|c|}
\hline Item & Quantity & Capacity & $\underset{\text { price }}{\text { List }}$ & $\begin{array}{l}\text { Total } \\
\text { cost* }\end{array}$ & $\begin{array}{l}\text { Esti- } \\
\text { mated } \\
\text { life }\end{array}$ & $\begin{array}{c}\text { Annual } \\
\text { deprecia- } \\
\text { tion }\end{array}$ \\
\hline Can conveyor. & 1 & $\ldots \ldots \ldots \ldots \ldots \ldots \ldots \ldots$ & 4,108 & 4,313 & 16 & 270 \\
\hline Weigh tank...... & 1 & $500 \mathrm{lbs} \ldots \ldots \ldots \ldots \ldots \ldots$ & 2,180 & 2,289 & 12 & 191 \\
\hline Scale............ & 1 & $500 \mathrm{lbs} \ldots \ldots \ldots \ldots \ldots \ldots$ & 838 & 880 & 17 & 52 \\
\hline Sample cabinet....... & 1 & 480 bottles $\ldots \ldots \ldots \ldots \ldots$ & 979 & 1,028 & 15 & 69 \\
\hline Can washer .......... & 1 & 10 cases per minute........ & 5,210 & 5,470 & 17 & 322 \\
\hline Pump............. & 1 & 2 hp centrifugal $\ldots \ldots \ldots \ldots$ & 369 & 387 & 12 & 32 \\
\hline Filters........... & 2 duplex & $34,500 \mathrm{lbs}$ per $\mathrm{hr} . \ldots \ldots \ldots$ & 982 & 2,062 & 15 & 137 \\
\hline Itemized total........ & . & $\ldots \ldots \ldots$ & $\ldots \ldots$ & 28,488 & . & 1,781 \\
\hline $\begin{array}{l}\text { Miscellaneous and in- } \\
\text { stallation } \dagger \ldots \ldots \ldots \ldots\end{array}$ & $\cdots$ & $\cdots \cdots \cdots \cdots \cdots \cdots \cdots \cdots \cdots \cdots$ & $\cdots \cdots$ & 2,849 & $\cdots$ & 178 \\
\hline Total installed cost $\ddagger \ldots$ & . & & & 31,300 & . & 1,960 \\
\hline
\end{tabular}

* Includes 3 per cent for sales tax and 2 per cent for freight cost.

$\dagger$ Includes cost of piping and wiring equipment.

$\mp$ Figures are rounded.

TABLE A-4

EQUIPMENT LIST, INVESTMENT, AND ANNUAL DEPRECIATION FOR RECEIVING STAGE, PLANT III

\begin{tabular}{|c|c|c|c|c|c|c|}
\hline Item & Quantity & Capacity & $\begin{array}{l}\text { List } \\
\text { price }\end{array}$ & $\begin{array}{l}\text { Total } \\
\text { cost* }\end{array}$ & $\begin{array}{c}\text { Esti- } \\
\text { mated } \\
\text { life }\end{array}$ & $\begin{array}{c}\text { Annual } \\
\text { deprecia- } \\
\text { tion }\end{array}$ \\
\hline & & & dollars & dollars & years & dollars \\
\hline Can conveyor.. & 1 & & 4,248 & 4,460 & 16 & 279 \\
\hline Weigh $\operatorname{tank} . . . .$. & 1 & $500 \mathrm{lbs} . \ldots \ldots \ldots \ldots$ & 2,180 & 2,289 & 12 & 191 \\
\hline Receiving vat........ & 1 & $1,000 \mathrm{lbs} \ldots \ldots \ldots \ldots \ldots \ldots$ & 1,040 & 1,092 & 12 & 91 \\
\hline Scale............... & 1 & $500 \mathrm{lbs} . \ldots \ldots \ldots \ldots \ldots \ldots$ & 838 & 880 & 17 & 52 \\
\hline Sample cabinet........ & 1 & 672 bottles.............. & 1,183 & 1,242 & 15 & 83 \\
\hline Can washer........... & 1 & 12 cans per minute....... & 5,485 & 5,759 & 17 & 339 \\
\hline \multirow[t]{2}{*}{ Pumps................ } & 1 & $3 \mathrm{hp}$ centrifugal $\ldots \ldots \ldots \ldots$ & 450 & 472 & 12 & 39 \\
\hline & 1 & $2 \mathrm{hp}$ centrifugal $\ldots \ldots \ldots \ldots$ & 368 & 386 & 12 & 32 \\
\hline Filters. . & 2 duplex & 37,300 lbs per hr per duplex & 1,032 & 2,167 & 15 & 144 \\
\hline Cabinet cooler. & 1 & $37,300 \mathrm{lbs}$ per $\mathrm{hr} . \ldots \ldots \ldots$ & 9,392 & 9,862 & 18 & 548 \\
\hline Ammonia control. & 1 & 172 tons $\ldots \ldots \ldots$ & 2,114 & 2,220 & 18 & 123 \\
\hline Itemized total. & . & & $\cdots$ & 30,829 & . & 1,921 \\
\hline $\begin{array}{l}\text { Miscellaneous and in- } \\
\text { stallation } \dagger \ldots \ldots \ldots \ldots\end{array}$ & .. & & ..... & 3,083 & . & 192 \\
\hline Total installed cost $\ddagger \ldots$ & .. & & $\ldots \ldots$ & 33,900 & . & 2,110 \\
\hline
\end{tabular}

* Includes 3 per cent for sales tax and 2 per cent for freight cost. $\dagger$ Includes cost of piping and wiring equipment.

$\ddagger$ Figures are rounded. 
TABLE A-5

EQUIPMENT LIST, INVESTMENT, AND ANNUAL DEPRECIATION FOR RECEIVING STAGE, PLANT IV

\begin{tabular}{|c|c|c|c|c|c|c|}
\hline Item & Quantity & Capacity & $\begin{array}{l}\text { List } \\
\text { price }\end{array}$ & $\begin{array}{l}\text { Total } \\
\text { cost* }\end{array}$ & $\begin{array}{l}\text { Esti- } \\
\text { mated } \\
\text { life }\end{array}$ & $\begin{array}{c}\text { Annual } \\
\text { deprecia- } \\
\text { tion }\end{array}$ \\
\hline & & & dollars & dollars & years & dollars \\
\hline \multirow[t]{2}{*}{ Can conveyors. } & 1 & .. & 4,066 & 4,269 & 16 & 267 \\
\hline & 1 & $\ldots \ldots \ldots, \cdots$ & 4,108 & 4,313 & 16 & 270 \\
\hline Weigh $\operatorname{tank} . \ldots \ldots$ & 2 & $500 \mathrm{lbs} . \ldots \ldots$ & 2,180 & 4,578 & 12 & 382 \\
\hline Receiving vats........ & 2 & $1,000 \mathrm{lbs} \ldots \ldots \ldots \ldots \ldots \ldots$ & 1,040 & 2,184 & 12 & 182 \\
\hline Scales............... & 2 & $500 \mathrm{lbs} \ldots \ldots \ldots \ldots \ldots \ldots$ & 838 & 1,760 & 17 & 104 \\
\hline Sample cabinet. . & 1 & 720 bottles.............. & 1,110 & 1,166 & 15 & 78 \\
\hline \multirow[t]{3}{*}{ Pumps............... } & 1 & 2 hp centrifugal.......... & 369 & 387 & 12 & 32 \\
\hline & 2 & $11 / 2 \mathrm{hp}$ centrifugal. . & 300 & 630 & 12 & 52 \\
\hline & 1 & $1 / 2$ hp centrifugal. . & 161 & 169 & 12 & 14 \\
\hline \multirow[t]{2}{*}{ Can washers. } & 1 & 8 cans per minute $\ldots \ldots \ldots$ & 4,965 & 5,213 & 17 & 307 \\
\hline & 1 & 10 cans per minute $\ldots \ldots \ldots$ & 5,210 & 5,470 & 17 & 322 \\
\hline \multirow[t]{2}{*}{ Filters. } & 1 duplex & 21,000 lbs per hr per unit. . & 1,082 & 1,136 & 15 & 76 \\
\hline & 2 duplex & 34,500 lbs per hr per duplex & 982 & 2,062 & 15 & 137 \\
\hline \multirow[t]{2}{*}{ Cabinet coolers......... } & 1 & $21,000 \mathrm{lbs}$ per $\mathrm{hr} \ldots \ldots \ldots \ldots$ & 5,946 & 6,243 & 18 & 347 \\
\hline & 1 & $34,500 \mathrm{lbs}$ per $\mathrm{hr}$. & 8,030 & 8,432 & 18 & 468 \\
\hline \multirow{2}{*}{ Ammonia controls...... } & 1 & 97 tons..... & 1,728 & 1,814 & 18 & 101 \\
\hline & 1 & 159 tons................ & 2,114 & 2,220 & 18 & 123 \\
\hline Itemized total.......... & . & & $\ldots \ldots$ & 52,046 & .. & 3,262 \\
\hline $\begin{array}{l}\text { Miscellaneous and in- } \\
\text { stallation } \dagger \ldots \ldots \ldots \ldots\end{array}$ & . & $\ldots \ldots$ & $\cdots \cdots$ & 5,205 & . & 326 \\
\hline Total installed cost $\ddagger \ldots$ & .. & & $\ldots \ldots$ & 57,300 & .. & 3,590 \\
\hline
\end{tabular}

* Includes 3 per cent for sales tax and 2 per cent for freight cost.

$\dagger$ Includes cost of piping and wiring equipment.

$\ddagger$ Figures are rounded. 
TABIE A-6

EQUIPMENT LIST, INVESTMENT, AND ANNUAL DEPRECIATION FOR RECEIVING STAGE, PLANT V

\begin{tabular}{|c|c|c|c|c|c|c|}
\hline Item & Quantity & Capacity & $\begin{array}{l}\text { List } \\
\text { price }\end{array}$ & $\begin{array}{l}\text { Total } \\
\text { cost* }\end{array}$ & $\begin{array}{l}\text { Esti- } \\
\text { mated } \\
\text { life }\end{array}$ & $\begin{array}{c}\text { Annual } \\
\text { deprecia- } \\
\text { tion }\end{array}$ \\
\hline & & & dollars & dollars & years & dollars \\
\hline \multirow[t]{2}{*}{ Can conveyors.......... } & 1 & $\ldots \ldots \ldots \ldots \ldots \ldots \ldots \ldots \ldots \ldots$ & 4,066 & 4,269 & 16 & 267 \\
\hline & 1 & 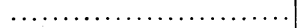 & 4,248 & 4,460 & 16 & 279 \\
\hline Weigh tanks....... & 2 & $500 \mathrm{lbs} . \ldots \ldots \ldots \ldots \ldots \ldots$ & 2,180 & 4,578 & 12 & 382 \\
\hline Receiving vats. & 2 & $1,000 \mathrm{lbs} . \ldots \ldots \ldots \ldots \ldots \ldots$ & 1,040 & 2,184 & 12 & 182 \\
\hline Scales................ & 2 & $500 \mathrm{lbs} . \ldots \ldots \ldots \ldots \ldots \ldots$ & 838 & 1,760 & 17 & 104 \\
\hline Sample cabinet. . & 1 & 1,008 bottles.............. & 1,460 & 1,533 & 15 & 102 \\
\hline \multirow[t]{2}{*}{ Can washers. } & 1 & 8 cans per minute $\ldots \ldots \ldots$ & 4,965 & 5,213 & 17 & 307 \\
\hline & 1 & 12 cans per minute...$\ldots \ldots$ & 5,485 & 5,759 & 17 & 339 \\
\hline \multirow[t]{4}{*}{ Pumps............... } & 1 & $1 / 2$ hp centrifugal. . & 161 & 169 & 12 & 14 \\
\hline & 1 & $11 / 2 \mathrm{hp}$ centrifugal. & 300 & 315 & 12 & 26 \\
\hline & 1 & $2 \mathrm{hp}$ centrifugal. . & 368 & 386 & 12 & 32 \\
\hline & 1 & $3 \mathrm{hp}$ centrifugal. .......... & 450 & 472 & 12 & 39 \\
\hline \multirow[t]{2}{*}{ Filters............... } & 1 duplex & $21,000 \mathrm{lbs}$ per $\mathrm{hr}$ per unit & 1,082 & 1,136 & 15 & 76 \\
\hline & 2 duplex & 37,300 lbs per hr per duplex & 1,032 & 2,167 & 15 & 144 \\
\hline \multirow[t]{2}{*}{ Cabinet coolers.......... } & 1 & $21,000 \mathrm{lbs}$ per $\mathrm{hr} . \ldots \ldots \ldots$ & 5,946 & 6.243 & 18 & 347 \\
\hline & 1 & $37,300 \mathrm{lbs}$ per $\mathrm{hr} . \ldots \ldots \ldots$ & 9,392 & 9,862 & 18 & 548 \\
\hline \multirow[t]{2}{*}{ Ammonia controls...... } & 1 & 97 tons....................... & 1,728 & 1,814 & 18 & 1,101 \\
\hline & 1 & 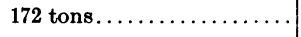 & 2,114 & 2,220 & 18 & 123 \\
\hline Itemized total.......... & . & & $\ldots \ldots$ & 54,540 & .. & 3,412 \\
\hline $\begin{array}{l}\text { Miscellaneous and in- } \\
\text { stallation } \dagger \ldots \ldots \ldots \ldots\end{array}$ & $\cdots$ & & $\cdots$ & 5,454 & $\cdots$ & 341 \\
\hline Total installed cost $\ddagger . .$. & .. & $\ldots \ldots$ & ...... & 60,000 & . & 3,750 \\
\hline
\end{tabular}

* Includes 3 per cent for sales tax and 2 per cent for freight cost.

$\dagger$ Includes cost of piping and wiring equipment.

$\ddagger$ Figures are rounded. 
TABLE A-7

EQUIPMENT LIST, INVESTMENT, AND ANNUAL DEPRECIATION FOR RECEIVING STAGE, PLANT VI

\begin{tabular}{|c|c|c|c|c|c|c|}
\hline Can conveyors......... & 2 & $\ldots \ldots$ & 4,248 & 8,921 & 16 & $\mathbf{5 5 8}$ \\
\hline Weigh tanks.......... & 2 & $500 \mathrm{lbs} \ldots \ldots \ldots \ldots \ldots$ & 2,180 & 4,578 & 12 & 382 \\
\hline Scales.............. & 2 & $500 \mathrm{lbs} \ldots \ldots \ldots \ldots \ldots \ldots$ & 838 & 1,760 & 17 & 104 \\
\hline Sample cabinet......... & 1 & 1,728 bottles $\ldots \ldots \ldots \ldots \ldots$ & 2,165 & 2,273 & 15 & 152 \\
\hline Can washers . . . . . . . & 2 & 12 cans per minute. . . . . . & 5,485 & 11,518 & 17 & 678 \\
\hline \multirow[t]{2}{*}{ Pumps............ } & 2 & $3 \mathrm{hp}$ centrifugal ......... & 450 & 945 & 12 & 79 \\
\hline & 2 & 2 hp centrifugal . . . . . . . & 368 & 773 & 12 & 64 \\
\hline Itemized total ......... & $\cdots$ & $\ldots \ldots \ldots \ldots \ldots \ldots \ldots \ldots \ldots \ldots$ & $\ldots \ldots$ & 61,448 & $\cdots$ & 3,831 \\
\hline $\begin{array}{l}\text { Miscellaneous and in- } \\
\text { stallation } \dagger \ldots \ldots \ldots \ldots\end{array}$ & . & $\cdots \cdots \cdots \cdots \cdots \cdots \cdots \cdots \cdots \cdots$ & & 6,145 & $\cdots$ & 383 \\
\hline Total installed cost $\ddagger \ldots .$. & . & 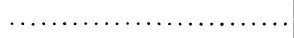 & $\cdots \cdots$ & 67,600 & $\cdots$ & 4,200 \\
\hline
\end{tabular}

* Includes 3 per cent for sales tax and 2 per cent for freight cost.

† Includes cost of piping and wiring equipment.

$\ddagger$ Figures are rounded.

TABLE A-8

EQUIPMENT LIST, INVESTMENT, AND ANNUAL DEPRECIATION FOR EVAPORATING STAGE, PLANT II

\begin{tabular}{|c|c|c|c|c|c|c|}
\hline Item & Quantity & Capacity & $\begin{array}{l}\text { List } \\
\text { price }\end{array}$ & $\begin{array}{l}\text { Total } \\
\text { cost* }\end{array}$ & $\begin{array}{c}\text { Esti- } \\
\text { mated } \\
\text { life }\end{array}$ & $\begin{array}{c}\text { Annual } \\
\text { deprecia- } \\
\text { tion }\end{array}$ \\
\hline Storage tanks.... & 4 & 8,000 gal $\ldots \ldots \ldots$ & 9,030 & 37,926 & 20 & 1,896 \\
\hline Pump............... & 1 & $\begin{array}{l}3 \text { hp positive action vari- } \\
\text { able speed } \ldots \ldots \ldots \ldots \ldots\end{array}$ & 1,144 & 1,201 & 12 & 100 \\
\hline Hotwell............. & 1 & $1,000 \mathrm{gal} \ldots \ldots \ldots \ldots \ldots \ldots$ & 1,110 & 1,166 & 20 & 58 \\
\hline Pump............. & 1 & $11 / 2$ hp centrifugal $\ldots \ldots \ldots$ & 199 & 209 & 12 & 17 \\
\hline Evaporator $† . . . .$. & 1 & 31,300 lbs per hr........ & 53,100 & 55,755 & 20 & 2,788 \\
\hline Surge tank........... & 1 & 300 gal. . . . . . . . . . . & 700 & 735 & 20 & 37 \\
\hline Homogenizer..... & 1 & 15,000 lbs per hr.... & 7,245 & 7,607 & 15 & 507 \\
\hline Refrigerator $\tan k \ldots \ldots$ & 1 & 3,000 gal $\ldots \ldots \ldots \ldots \ldots \ldots$ & 7,770 & 8,158 & 20 & 408 \\
\hline Itemized total. & $\cdots$ & & $\ldots \ldots$ & 144,122 & $\cdots$ & 7,456 \\
\hline $\begin{array}{l}\text { Miscellaneous and in- } \\
\text { stallation } \ddagger \ldots \ldots \ldots \ldots\end{array}$ & $\cdots$ & $\cdots \cdots \cdots$ & $\cdots \cdots$ & 7,206 & $\cdots$ & 373 \\
\hline Total installed cost\$. & . & & $\ldots \ldots$ & 151,300 & $\cdots$ & 7.830 \\
\hline
\end{tabular}

* Includes 3 per cent for sales tax and 2 per cent freight cost.

+ Cost of evaporator includes preheaters and auxiliary equipment.

$\ddagger$ Includes piping and wiring equipment.

$\$$ Figures are rounded. 
TABLE A-9

EQUIPMENT LIST, INVESTMENT, AND ANNUAL DEPRECIATION FOR EVAPORATING S'TAGE, PLANT III

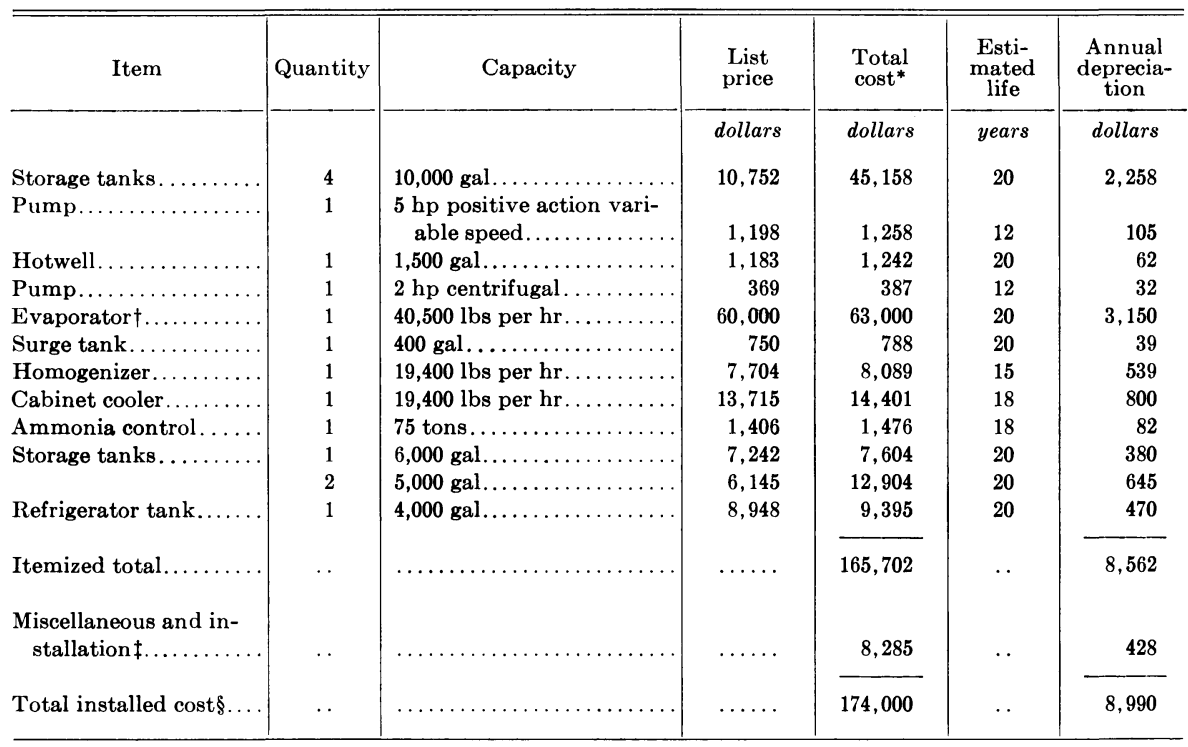

* Includes 3 per cent for sales tax and 2 per cent freight cost.

+ Cost of evaporator includes preheaters and auxiliary equipment.

Includes piping and wiring equipment.

$\$$ Figures are rounded. 
TABLE A-10

EQUIPMENT LIST, INVESTMENT, AND ANNUAL DEPRECIATION FOR EVAPORATING STAGE, PLANT IV

\begin{tabular}{|c|c|c|c|c|c|c|}
\hline Item & Quantity & Capacity & $\begin{array}{l}\text { List } \\
\text { price }\end{array}$ & $\begin{array}{l}\text { Total } \\
\text { cost* }\end{array}$ & $\begin{array}{c}\text { Esti- } \\
\text { mated } \\
\text { life }\end{array}$ & $\underset{\text { tion }}{\text { Annual }}$ \\
\hline & & & dollars & dollars & years & dollars \\
\hline Storage tanks... & 5 & $10,000 \mathrm{gal}$. & 10,752 & 56,448 & 20 & 2,822 \\
\hline Pump................ & 1 & $\begin{array}{l}5 \text { hp positive action vari- } \\
\text { able speed } \ldots \ldots \ldots \ldots \ldots\end{array}$ & 1,198 & 1,258 & 12 & 105 \\
\hline Hotwell.............. & 1 & 1,500 gal. $\ldots \ldots \ldots \ldots \ldots$ & 1,183 & 1,242 & 20 & 62 \\
\hline Pump............... & 1 & $3 \mathrm{hp}$ centrifugal.......... & 467 & 490 & 12 & 41 \\
\hline Evaporator $\dagger$. . & 1 & 45,700 lbs per $\mathrm{hr} . \ldots \ldots$ & 64,900 & 68,145 & 20 & 3,407 \\
\hline Surge tank........ & 1 & 400 gal $\ldots \ldots \ldots \ldots \ldots \ldots$ & 750 & 788 & 20 & 39 \\
\hline Homogenizer........... & 1 & $21,800 \mathrm{lbs}$ per $\mathrm{hr} \ldots \ldots \ldots \ldots$ & 7,796 & 8,186 & 15 & 546 \\
\hline Cabinet cooler........... & 1 & $21,800 \mathrm{lbs}$ per $\mathrm{hr} . \ldots \ldots \ldots$ & 15,807 & 16,597 & 18 & 922 \\
\hline Ammonia control. & 1 & 84 tons. . . . . . . . . . & 1,782 & 1,871 & 18 & 104 \\
\hline \multirow[t]{2}{*}{ Storage tanks......... } & 2 & 7,000 gal.. & 8,146 & 17,107 & 20 & 855 \\
\hline & 1 & 6,000 gal. & 7,242 & 7,604 & 20 & 380 \\
\hline Refrigerator tank. & 1 & $4,000 \mathrm{gal} .$. & 8,948 & 9,395 & 20 & 470 \\
\hline Itemized total. . & .. & & $\ldots \ldots$ & 189,131 & .. & 9,753 \\
\hline $\begin{array}{l}\text { Miscellaneous and in- } \\
\text { stallation } \ddagger \ldots \ldots \ldots \ldots\end{array}$ & .. & & ..... & 9,457 & . & 488 \\
\hline Total installed cost $\$ . .$. & .. & & $\ldots \ldots$ & 198,600 & $\ldots$ & 10,200 \\
\hline
\end{tabular}

* Includes 3 per cent for sales tax and 2 per cent freight cost.

† Cost of evaporator includes preheaters and auxiliary equipment.

$¥$ Includes piping and wiring equipment.

Figures are rounded. 
TABLE A-11

EQUIPMENT LIST, INVESTMENT, AND ANNUAL DEPRECIATION FOR EVAPORATING STAGE, PLANT V

\begin{tabular}{|c|c|c|c|c|c|c|}
\hline Item & Quantity & Capacity & $\begin{array}{l}\text { List } \\
\text { price }\end{array}$ & $\begin{array}{l}\text { Total } \\
\text { cost* }\end{array}$ & $\begin{array}{c}\text { Esti- } \\
\text { mated } \\
\text { life }\end{array}$ & $\begin{array}{c}\text { Annual } \\
\text { deprecia- } \\
\text { tion }\end{array}$ \\
\hline & & & dollars & dollars & years & dollars \\
\hline Storage tanks. & 6 & 10,000 gal. & 10,752 & 67,738 & 20 & 3,387 \\
\hline Pump.......... & 1 & $\begin{array}{l}5 \text { hp positive action vari- } \\
\text { able speed } \ldots \ldots \ldots \ldots \ldots \ldots\end{array}$ & 1,198 & 1,258 & 12 & 105 \\
\hline Hotwell............... & 1 & 1,500 gal $\ldots \ldots \ldots \ldots \ldots \ldots$ & 1,183 & 1,242 & 20 & 62 \\
\hline Pump............... & 1 & $3 \mathrm{hp}$ centrifugal .......... & 467 & 490 & 12 & 41 \\
\hline Evaporator $\dagger \ldots$ & 1 & 47,800 lbs per hr.... & 70,000 & 73,500 & 20 & 3,675 \\
\hline Surge tank........... & 1 & $500 \mathrm{gal} \ldots \ldots \ldots \ldots \ldots \ldots$ & 896 & 941 & 20 & 47 \\
\hline \multirow[t]{2}{*}{ Homogenizers.......... } & 1 & $18,200 \mathrm{lbs}$ per $\mathrm{hr} . \ldots \ldots \ldots$ & 7,796 & 8,186 & 15 & 546 \\
\hline & 1 & 4,600 lbs per $\mathrm{hr} . \ldots$. & 5,337 & 5,604 & 15 & 374 \\
\hline Cabinet cooler.... & 1 & 22,800 lbs per $h r \ldots \ldots \ldots \ldots$ & 16,676 & 17,510 & 18 & 973 \\
\hline Ammonia control. & 1 & 88 tons...$\ldots \ldots \ldots$ & 1,782 & 1,871 & 18 & 104 \\
\hline \multirow[t]{2}{*}{ Storage tanks......... } & 1 & 10,000 gal. . & 10,752 & 11,290 & 20 & 564 \\
\hline & 2 & 7,000 gal. & 8,146 & 17,107 & 20 & 855 \\
\hline Refrigerator tank....... & 1 & 4,000 gal $\ldots \ldots \ldots \ldots \ldots \ldots$ & 8,948 & 9,395 & 20 & 470 \\
\hline Itemized total. & .. & & .. & 216,132 & .. & 11,203 \\
\hline $\begin{array}{l}\text { Miscellaneous and in- } \\
\text { stallation } \neq \ldots \ldots \ldots \ldots\end{array}$ & . & & . & 10,807 & . & 560 \\
\hline Total installed cost $\S \ldots$ & .. & $\ldots$ & $\cdots \cdots$ & 226,900 & . & 11,800 \\
\hline
\end{tabular}

* Includes 3 per cent for sales tax and 2 per cent freight cost.

t Cost of evaporator includes preheaters and auxiliary equipment.

¥ Includes piping and wiring equipment.

$\S$ Figures are rounded. 
TABLE A-12

EQUIPMENT LIST, INVESTMENT, AND ANNUAL DEPRECIATION FOR EVAPORATING STAGE, PLANT VI

\begin{tabular}{|c|c|c|c|c|c|c|}
\hline Item & Quantity & Capacity & $\underset{\text { price }}{\text { List }}$ & $\begin{array}{l}\text { Total } \\
\text { cost* }\end{array}$ & $\begin{array}{c}\text { Esti- } \\
\text { mated } \\
\text { life }\end{array}$ & $\begin{array}{c}\text { Annual } \\
\text { deprecia- } \\
\text { tion }\end{array}$ \\
\hline & & & dollars & dollars & years & dollars \\
\hline Storage tanks. & 7 & 10,000 gal. & 10,752 & 79,027 & 20 & 3,951 \\
\hline Pump............ & 1 & $\begin{array}{l}71 / 2 \mathrm{hp} \text { positive action vari- } \\
\text { able speed.............. }\end{array}$ & 1,307 & 1,372 & 12 & 114 \\
\hline Hotwell.............. & 1 & 2,000 gal $\ldots \ldots \ldots \ldots \ldots \ldots$ & 1,400 & 1,470 & 20 & 74 \\
\hline Pump............... & 1 & 5 hp centrifugal ..... & 500 & 525 & 12 & 44 \\
\hline Evaporator $\dagger$. & 1 & $67,600 \mathrm{lbs}$ per $\mathrm{hr}$. & 85,800 & 90,090 & 20 & 4,504 \\
\hline Surge tank. . & 1 & $600 \mathrm{gal} \ldots \ldots \ldots \ldots \ldots \ldots$ & 900 & 945 & 20 & 47 \\
\hline \multirow[t]{2}{*}{ Homogenizers......... } & 1 & 23,300 lbs per $\mathrm{hr} . \ldots \ldots \ldots$ & 7,796 & 8,186 & 15 & 546 \\
\hline & 1 & 9,000 lbs per $\mathrm{hr} . \ldots \ldots$ & 5,969 & 6,267 & 15 & 418 \\
\hline Cabinet cooler. & 1 & 32,300 lbs per $\mathrm{hr} . .$. & 21,390 & 22,460 & 18 & 1,248 \\
\hline Ammonia control. & 1 & 125 tons $\ldots \ldots \ldots \ldots \ldots \ldots$ & 1,869 & 1,962 & 18 & 109 \\
\hline Storage tanks. & 4 & 8,000 gal. & 9,030 & 37,926 & 20 & 1,896 \\
\hline Refrigerator tank. & 1 & 4,000 gal. & 8,948 & 9,395 & 20 & 470 \\
\hline Itemized total. & .. & & $\ldots \ldots$ & 259,625 & . & 13,421 \\
\hline $\begin{array}{l}\text { Miscellaneous and in- } \\
\text { stallation } \ddagger \ldots \ldots \ldots \ldots\end{array}$ & .. & & $\cdots \cdots$ & 12,981 & . & 671 \\
\hline Total installed cost $\S \ldots$. & .. & $\ldots$ & $\ldots \ldots$ & 272,600 & .. & 14,100 \\
\hline
\end{tabular}

* Includes 3 per cent for sales tax and 2 per cent freight cost.

† Cost of evaporator includes preheaters and auxiliary equipment.

$\ddagger$ Includes piping and wiring equipment.

$\$$ Figures are rounded.

TABLE A-13

EQUIPMENT LIST, INVESTMENT, AND ANNUAL DEPRECIATION FOR CANNING STAGE, PLANT II

\begin{tabular}{|c|c|c|c|c|c|c|}
\hline Item & Quantity & Capacity & $\begin{array}{l}\text { List } \\
\text { price }\end{array}$ & $\begin{array}{l}\text { Total } \\
\text { cost* }\end{array}$ & $\underset{\text { life }}{\text { Esti- }}$ & $\begin{array}{c}\text { Annual } \\
\text { deprecia- } \\
\text { tion }\end{array}$ \\
\hline & & & dollars & dollars & years & dollars \\
\hline Pump.............. & 1 & $1 / 2 \mathrm{hp}$ centrifugal $\ldots \ldots \ldots$ & 226 & 237 & 12 & 20 \\
\hline Can fillers $\nmid \ldots . . .$. & 2 & 48-cell, 130 cans per minute & 7,619 & 16,000 & 12 & 1,333 \\
\hline Labeler........... & 1 & 260 cans per minute...... & 1,500 & 1,575 & 15 & 105 \\
\hline Can ejector........ & 1 & 260 cans per minute...... & 850 & 892 & 15 & 59 \\
\hline Caser........... & 1 & 5.42 cases per minute..... & 950 & 998 & 15 & 67 \\
\hline Gluer and sealer.... & 1 & 5.42 cases per minute... & 3,350 & 3,518 & 20 & 176 \\
\hline Itemized total. & . & & $\ldots \ldots$ & 23,220 & .. & 1,760 \\
\hline $\begin{array}{l}\text { Sterilizer freight and } \\
\text { installation......... }\end{array}$ & $\cdots$ & & $\ldots \ldots$ & 4,000 & 20 & 200 \\
\hline $\begin{array}{l}\text { Miscellaneous and in- } \\
\text { stallation } \ddagger \ldots \ldots \ldots . .\end{array}$ & .. & & $\ldots \ldots$ & 2,322 & .. & 176 \\
\hline Total installed cost $\S .$. & .. & & $\ldots \ldots$ & 29,500 & . & 2,140 \\
\hline
\end{tabular}

* Includes 3 per cent for sales tax and 2 per cent for freight cost.

$\dagger$ Includes leak detector and lightweight detector.

$\ddagger$ Includes piping and wiring equipment.

$\$$ Figures are rounded. 
TABLE A-14

EQUIPMENT LIST, INVESTMENT, AND ANNUAL DEPRECIATION FOR CANNING STAGE, PLANT III

\begin{tabular}{|c|c|c|c|c|c|c|}
\hline Item & Quantity & Capacity & $\begin{array}{l}\text { List } \\
\text { price }\end{array}$ & $\begin{array}{l}\text { Total } \\
\text { cost* }\end{array}$ & $\begin{array}{c}\text { Esti- } \\
\text { mated } \\
\text { life }\end{array}$ & $\underset{\text { deprecia- }}{\text { Annual }}$ \\
\hline Pump............. & 1 & $1 / 2 \mathrm{hp}$ centrifugal $\ldots \ldots \ldots$ & 226 & 237 & 12 & 20 \\
\hline Can fillers $\dagger$. & 2 & 60 -cell, 160 cans per minute & 8,712 & 18,295 & 12 & 1,525 \\
\hline Can ejector........... & 1 & 320 cans per minute. . . . . & 850 & 892 & 15 & 59 \\
\hline Caser . . . . . . . . . . & 1 & $62 / 3$ cases per minute...... & 950 & 998 & 15 & 67 \\
\hline Gluer and sealer....... & 1 & $62 / 3$ cases per minute...... & 3,350 & 3,518 & 20 & 176 \\
\hline Can converger... & 1 & 320 cans per minute. & 800 & 840 & 15 & 56 \\
\hline $\begin{array}{l}\text { Miscellaneous and in- } \\
\text { stallation } \ddagger \ldots \ldots \ldots \ldots\end{array}$ & $\cdots$ & $\cdots \cdots \cdots \cdots \cdots \cdots \cdots \cdots$ & $\ldots \ldots$ & 2,680 & $\cdots$ & 204 \\
\hline Total installed cost $\$ . .$. & . & & $\ldots \ldots$ & 33,500 & $\cdots$ & 2,440 \\
\hline
\end{tabular}

* Includes 3 per cent for sales tax and 2 per cent for freight cost.

† Includes leak detector and lightweight detector.

† Includes piping and wiring equipment.

$\S$ Figures are rounded.

TABLE A-15

EQUIPMENT LIST, INVESTMENT, AND ANNUAL DEPRECIATION FOR CANNING STAGE, PLANT IV

\begin{tabular}{|c|c|c|c|c|c|c|}
\hline Item & Quantity & Capacity & $\begin{array}{c}\text { List } \\
\text { price }\end{array}$ & $\begin{array}{l}\text { Total } \\
\text { cost* }\end{array}$ & $\begin{array}{c}\text { Esti- } \\
\text { mated } \\
\text { life }\end{array}$ & $\begin{array}{l}\text { Annual } \\
\text { deprecia- } \\
\text { tion }\end{array}$ \\
\hline & & & dollars & dollars & years & dollars \\
\hline Pump................ & 1 & $3 / 4$ hp centrifugal .......... & 300 & 315 & 12 & 26 \\
\hline Can fillerst............... & 3 & 48 -cell, 130 cans per minute & 7,619 & 24,000 & 12 & 2,000 \\
\hline Labeler. . . . . . . . . & 1 & 390 cans per minute....... & 1,925 & 2,021 & 15 & 135 \\
\hline Can ejector........... & 1 & 390 cans per minute........ & 850 & 892 & 15 & 59 \\
\hline Caser............ & 1 & 8.1 cases per minute........ & 2,750 & 2,888 & 15 & 193 \\
\hline Gluer and sealer...... & 1 & 8.1 cases per minute........ & 3,550 & 3,728 & 20 & 186 \\
\hline Can converger.......... & 1 & 390 cans per minute........ & 800 & 840 & 15 & 56 \\
\hline Itemized total. & .. & & .. & 34,684 & .. & 2,655 \\
\hline $\begin{array}{l}\text { Sterilizer freight and } \\
\text { installation.......... }\end{array}$ & .. & & & 4,000 & 20 & 200 \\
\hline Miscellaneous and in- & 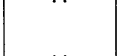 & & & 3.468 & 20 & 266 \\
\hline Total installed cost $\S$. & .. & & $\ldots \ldots$ & 42,200 & $\ldots$ & 3,120 \\
\hline
\end{tabular}

* Includes 3 per cent for sales tax and 2 per cent for freight cost.

$\dagger$ Includes leak detector and lightweight detector.

¥ Includes piping and wiring equipment.

$\$$ Figures are rounded. 
TABLE A-16

EQUIPMENT LIST, INVESTMENT, AND ANNUAL DEPRECIATION FOR CANNING STAGE, PLANT V

\begin{tabular}{|c|c|c|c|c|c|c|}
\hline Item & Quantity & Capacity & $\begin{array}{c}\text { List } \\
\text { price }\end{array}$ & $\begin{array}{l}\text { Total } \\
\text { cost* }\end{array}$ & $\begin{array}{c}\text { Esti- } \\
\text { mated } \\
\text { life }\end{array}$ & $\begin{array}{c}\text { Annual } \\
\text { deprecia- } \\
\text { tion }\end{array}$ \\
\hline & & & dollars & dollars & years & dollars \\
\hline Pump.. & 1 & $1 \mathrm{hp}$ centrifugal. & 354 & 372 & 12 & 31 \\
\hline Can fillerst. & 3 & 60 -cell, 160 cans per minute & 8,712 & 27,443 & 12 & 2,287 \\
\hline Labeler. & 1 & 480 cans per minute.. & 1,925 & 2,021 & 15 & 135 \\
\hline Can ejector..... & 1 & 480 cans per minute... & 850 & 892 & 15 & 59 \\
\hline Caser. . . . . . . . . . . & 1 & 10 cases per minute $\ldots \ldots \ldots$ & 2,750 & 2,888 & 15 & 193 \\
\hline Gluer and sealer....... & 1 & 10 cases per minute....... & 3,750 & 3,938 & 20 & 197 \\
\hline Can converger......... & 1 & 480 cans per minute...... & 1,000 & 1,050 & 15 & 70 \\
\hline Itemized total... & . & & $\ldots \ldots$ & 38,604 & .. & 2,972 \\
\hline $\begin{array}{l}\text { Sterilizer freight and } \\
\text { installation........ }\end{array}$ & .. & & $\ldots$ & 6,000 & 20 & 300 \\
\hline $\begin{array}{l}\text { Miscellaneous and in- } \\
\text { stallation } \ddagger \ldots \ldots \ldots \ldots\end{array}$ & . & & ...... & 3,860 & . & 297 \\
\hline Total installed cost $\S$ & .. & & $\ldots \ldots$ & 48,500 & .. & 3,570 \\
\hline
\end{tabular}

* Includes 3 per cent for sales tax and 2 per cent for freight cost.

† Includes leak detector and lightweight detector.

$\ddagger$ Includes piping and wiring equipment.

$\$$ Figures are rounded.

TABLE A-17

EQUIPMENT LIST, INVESTMENT, AND ANNUAL DEPRECIATION FOR CANNING STAGE, PLANT VI

\begin{tabular}{|c|c|c|c|c|c|c|}
\hline Item & Quantity & Capacity & $\begin{array}{c}\text { List } \\
\text { price }\end{array}$ & $\begin{array}{l}\text { Total } \\
\text { cost* }\end{array}$ & $\begin{array}{c}\text { Esti- } \\
\text { mated } \\
\text { life }\end{array}$ & $\begin{array}{c}\text { Annual } \\
\text { deprecia- } \\
\text { tion }\end{array}$ \\
\hline & & & dollars & dollars & years & dollars \\
\hline Pump... & 1 & $2 \mathrm{hp}$ centrifugal........ & 397 & 417 & 12 & 35 \\
\hline Can fillers $\nmid \ldots \ldots \ldots \ldots$ & 4 & 60 -cell, 160 cans per minute & 8,712 & 36,590 & 12 & 3,049 \\
\hline Labeler.............. & 1 & 640 cans per minute....... & 1,925 & 2,021 & 15 & 135 \\
\hline Can ejector............ & 1 & 640 cans per minute...... & 850 & 892 & 15 & 59 \\
\hline Caser................ & 1 & $131 / 3$ cases per minute...... & 2,750 & 2,888 & 15 & 193 \\
\hline Gluer and sealer........ & 1 & $131 / 3$ cases per minute...... & 3,950 & 4,148 & 20 & 207 \\
\hline Can converger.... & 1 & 640 cans per minute....... & 1,500 & 1,575 & 15 & 105 \\
\hline Itemized total... & . & & ..... & 48,531 & . & 3,783 \\
\hline $\begin{array}{l}\text { Sterilizer freight and } \\
\text { installation.......... }\end{array}$ & . & & 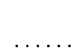 & 8,000 & 20 & 400 \\
\hline $\begin{array}{l}\text { Miscellaneous and in- } \\
\text { stallation } \ddagger \ldots \ldots \ldots \ldots\end{array}$ & . & & & 4,853 & . & 378 \\
\hline Total installed cost $\S$. & . & . & $\ldots$ & 61,400 & . & 4,560 \\
\hline
\end{tabular}

* Includes 3 per cent for sales tax and 2 per cent for freight cost.

$\dagger$ Includes leak detector and lightweight detector.

$\ddagger$ Includes piping and wiring equipment.

\$ Figures are rounded. 
TABLE A-18

EQUIPMENT LIST, INVESTMENT, AND ANNUAL DEPRECIATION FOR UTILITY STAGE, PLANT II

\begin{tabular}{|c|c|c|c|c|c|c|}
\hline Item & Quantity & Depreciation & List price & Total cost* & $\begin{array}{c}\text { Esti- } \\
\text { mated } \\
\text { life }\end{array}$ & $\underset{\substack{\text { Annual } \\
\text { tion }}}{\text { Anecia- }}$ \\
\hline \multirow{3}{*}{$\begin{array}{l}\text { Refrigerator compres- } \\
\text { sors.................. }\end{array}$} & & & dollars & dollars & years & dollars \\
\hline & 2 & 4 cyl. $31 / 2 \times 31 / 2-30.1$ tons... & 3,329 & 6,990 & 20 & 350 \\
\hline & 2 & 6 cyl. $5 \times 5-101.5$ tons. . . . & 8,255 & 17,336 & 20 & 867 \\
\hline \multirow[t]{2}{*}{ Ammonia condensers... } & 3 & evaporative -62 tons. . & 4,815 & 15,167 & 20 & 758 \\
\hline & 1 & evaporative -75 tons... & 5,720 & 6,006 & 20 & 300 \\
\hline $\begin{array}{l}\text { Refrigerator miscella- } \\
\text { neous and installation }\end{array}$ & $\cdots$ & & & 13,650 & 20 & 682 \\
\hline Steam boilers........... & 2 & $200 \mathrm{hp} \ldots \ldots \ldots \ldots \ldots$ & 14,549 & 30,553 & 20 & 1,528 \\
\hline $\begin{array}{l}\text { Boiler miscellaneous } \\
\text { and installation } \dagger . . .\end{array}$ & .. & & & 7,640 & 20 & 382 \\
\hline Water system .......... & 1 & 1,100 gal per minute $\ldots \ldots$ & $\cdots \cdots$ & 16,200 & 20 & 810 \\
\hline Fork-lift truck........ & 1 & 4,000 lbs electric $\ldots \ldots \ldots \ldots$ & 8,000 & 8,400 & 10 & 840 \\
\hline Pallets.............. & 1,390 & $3^{\prime} \times 4^{\prime}$ wooden $\ldots \ldots \ldots \ldots$ & 4.25 & 6,203 & 10 & 620 \\
\hline Total installed cost $\uparrow \ldots$ & .. & & $\cdots$ & 128,100 & .. & 7,140 \\
\hline
\end{tabular}

* Includes 3 per cent for sales tax and 2 per cent for freight cost.

$\dagger$ Figures are rounded.

TABLE A-19

EQUIPMENT LIST, INVESTMENT, AND ANNUAL DEPRECIATION FOR UTILITY STAGE, PLANT III

\begin{tabular}{|c|c|c|c|c|c|c|}
\hline Item & Quantity & Depreciation & List price & Total cost* & $\begin{array}{c}\text { Esti- } \\
\text { mated } \\
\text { life }\end{array}$ & $\underset{\substack{\text { Annual } \\
\text { deprecia- }}}{ }$ \\
\hline & & & dollars & dollars & years & dollars \\
\hline $\begin{array}{l}\text { Refrigerator compres- } \\
\text { sors } \ldots \ldots \ldots \ldots \ldots \ldots\end{array}$ & 3 & 6 cyl. $5 \times 5-101.5$ tons.... & 8,255 & 26,003 & 20 & 1,300 \\
\hline Ammonia condensers... & 4 & Evaporative -75 tons...... & 5,720 & 24,024 & 20 & 1,201 \\
\hline $\begin{array}{l}\text { Refrigerator miscella- } \\
\text { neous and installation }\end{array}$ & .. & & & 15,008 & 20 & 750 \\
\hline Steam boilers......... & 2 & $250 \mathrm{hp} . .$. & 16,193 & 34,005 & 20 & 1,700 \\
\hline $\begin{array}{l}\text { Boiler miscellaneous } \\
\text { and installation.... }\end{array}$ & . & & & 8,500 & 20 & 425 \\
\hline Water system ......... & 1 & 1,400 gal per minute. . & & 19,000 & 20 & 950 \\
\hline Fork-lift truck........ & 1 & 4,000 lbs electric $\ldots \ldots \ldots$ & 8,000 & 8,400 & 10 & 840 \\
\hline Pallets............... & 1,720 & $3^{\prime} \times 4^{\prime}$ wooden...$\ldots \ldots \ldots$ & 4.25 & 7,676 & 10 & 768 \\
\hline Total installed cost $\uparrow \ldots$ & .. & & ...... & 142,600 & .. & 7,930 \\
\hline
\end{tabular}

* Includes 3 per cent for sales tax and 2 per cent for freight cost.

$\$$ Figures are rounded. 
TABLE A-20

EQUIPMENT LIST, INVESTMENT, AND ANNUAL DEPRECIATION FOR UTILITY STAGE, PLANT IV

\begin{tabular}{|c|c|c|c|c|c|c|}
\hline Item & Quantity & Depreciation & List price & Total cost* & $\begin{array}{c}\text { Esti- } \\
\text { mated } \\
\text { life }\end{array}$ & $\underset{\substack{\text { Annual } \\
\text { tion }}}{\stackrel{\text { tiocia- }}{ }}$ \\
\hline & & & dollars & dollars & years & dollars \\
\hline $\begin{array}{l}\text { Refrigerator compres- } \\
\text { sors } \ldots \ldots \ldots \ldots \ldots\end{array}$ & 4 & 6 cyl. $5 \times 5-101.5$ tons. . & 8,255 & 34,671 & 20 & 1,734 \\
\hline Ammonia condensers.. & 3 & Evaporative -62 tons.. & 4,815 & 15,167 & 20 & 758 \\
\hline & 3 & Evaporative -75 tons...... & 5,720 & 18,091 & 20 & 901 \\
\hline $\begin{array}{l}\text { Refrigerator miscella- } \\
\text { neous and installation }\end{array}$ & . & $\ldots$ & $\ldots \ldots$ & 20,357 & 20 & 1,018 \\
\hline Steam boilers......... & 2 & $300 \mathrm{hp} \ldots \ldots \ldots \ldots \ldots \ldots$ & 17,337 & 36,408 & 20 & 1,820 \\
\hline $\begin{array}{l}\text { Boiler miscellaneous } \\
\text { and installation... }\end{array}$ & o & & & 9,100 & 20 & 455 \\
\hline Water system........ & 1 & 1,700 gal. per minute $\ldots \ldots$ & $\ldots \ldots$ & 22,000 & 20 & 1,100 \\
\hline Fork-lift truck........ & 1 & $4,000 \mathrm{lbs}$ electric $\ldots \ldots \ldots \ldots$ & 8,000 & 8,400 & 10 & 840 \\
\hline Pallets............... & 2,080 & $3^{\prime} \times 4^{\prime}$ wooden..$\ldots \ldots \ldots$ & 4.25 & 9,282 & 10 & 928 \\
\hline Total installed cost $\dagger \ldots$. & .. & $\ldots$ & $\ldots \ldots$ & 173,400 & .. & 9,550 \\
\hline
\end{tabular}

* Includes 3 per cent for sales tax and 2 per cent for freight cost. $\S$ Figures are rounded.

TABLE A-21

EQUIPMENT LIST, INVESTMENT, AND ANNUAL DEPRECIATION FOR UTILITY STAGE, PLANT V

\begin{tabular}{|c|c|c|c|c|c|c|}
\hline Item & Quantity & Depreciation & List price & Total cost* & $\begin{array}{c}\text { Esti- } \\
\text { mated } \\
\text { life }\end{array}$ & $\underset{\substack{\text { Annual } \\
\text { teprecia- }}}{ }$ \\
\hline & & & dollars & dollars & years & dollars \\
\hline $\begin{array}{l}\text { Refrigerator compres- } \\
\text { sors } \ldots \ldots \ldots \ldots \ldots \ldots\end{array}$ & 4 & 6 cyl. $5 \times 5-101.5$ tons... & 8,255 & 34,671 & 20 & 1,734 \\
\hline & 1 & 4 cyl. $31 / 2 \times 31 / 2-30.1$ tons. & 3,329 & 3,495 & 20 & 175 \\
\hline Ammonia condensers... & 1 & Evaporative -62 tons...... & 4,815 & 5,056 & 20 & 253 \\
\hline & 5 & Evaporative -75 tons...... & 5,720 & 30,030 & 20 & 1,502 \\
\hline $\begin{array}{l}\text { Refrigerator miscella- } \\
\text { neous and installation }\end{array}$ & . & & ..... & 21,976 & 20 & 1,099 \\
\hline Steam boilers.......... & 2 & $350 \mathrm{hp} \ldots$ & 18,462 & 38,770 & 20 & 1,938 \\
\hline $\begin{array}{l}\text { Boiler miscellaneous } \\
\text { and installation..... }\end{array}$ & & & & 9,690 & 20 & 484 \\
\hline Water system......... & $\ddot{1}$ & 2,000 gal per minute $\ldots \ldots$ & $\cdots \cdots$ & 25,000 & 20 & 1,250 \\
\hline Fork-lift truck......... & 1 & $4,000 \mathrm{lbs}$ electric $\ldots \ldots \ldots \ldots$ & 8,000 & 8,400 & 10 & 840 \\
\hline Pallets.............. & 2,580 & $3^{\prime} \times 4^{\prime}$ wooden $\ldots \ldots \ldots \ldots$ & 4.25 & 11,513 & 10 & 1,151 \\
\hline Total installed cost $\dagger \ldots$. & .. & $\ldots$ & $\ldots \ldots$ & 188,600 & .. & 10,400 \\
\hline
\end{tabular}

* Includes 3 per cent for sales tax and 2 per cent for freight cost.

$\dagger$ Figures are rounded. 
TABLE A-22

EQUIPMENT LIST, INVESTMENT, AND ANNUAL DEPRECIATION FOR UTILITY STAGE, PLANT VI

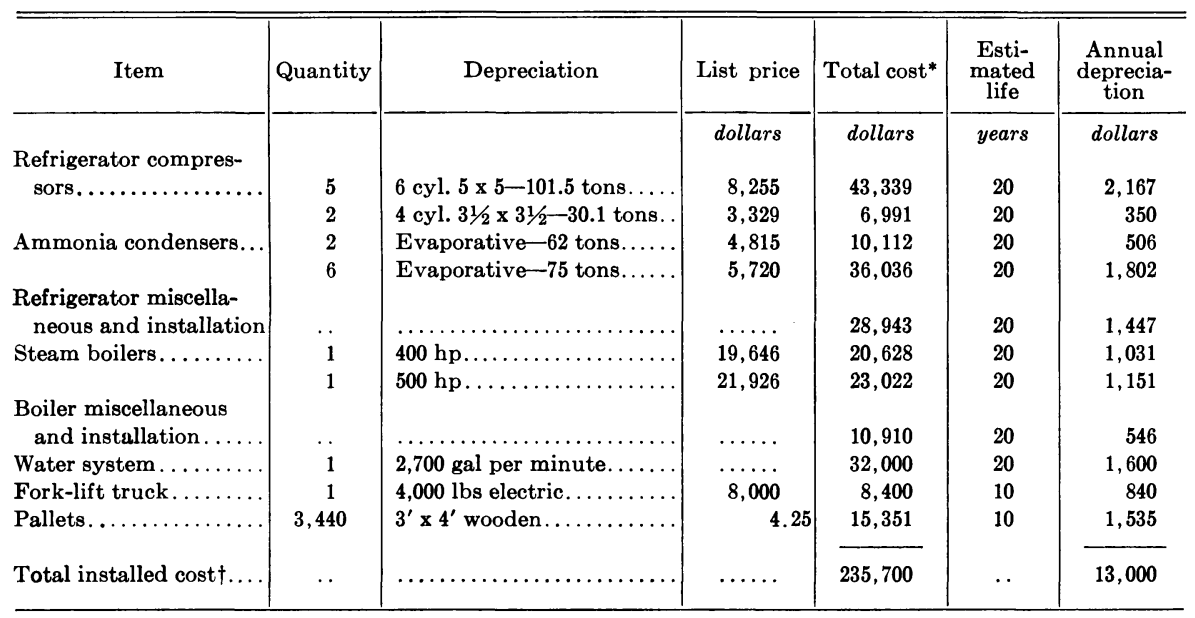

* Includes 3 per cent for sales tax and 2 per cent for freight cost.

$\dagger$ Figures are rounded. 

The journal Hilgardia is published at irregular intervals, in volumes of about 600 pages. The number of issues per volume varies. Subscriptions are not sold. The periodical is sent as published only to libraries, or to institutions in foreign countries having publications to offer in exchange.

You may obtain a single copy of any issue free, as long as the supply lasts; please request by volume and issue number from:
Agricultural Publications
Room 22, Giannini Hall
University of California
Berkeley 4, California

The limit to nonresidents of California is 10 separate issues on a single order. A list of the issues still available will be sent on request. 
(it)

(4) $x=2$

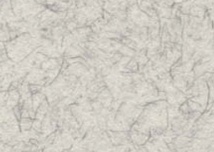

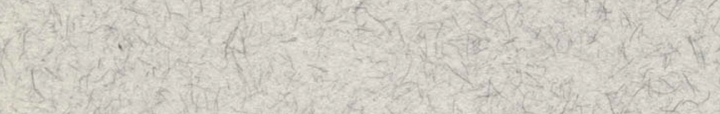

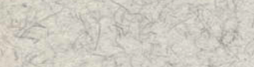

$-5^{2}-(2)+1$

a

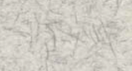

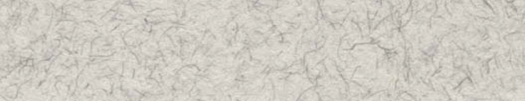

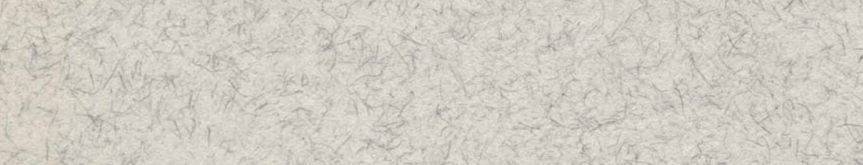

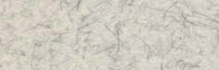

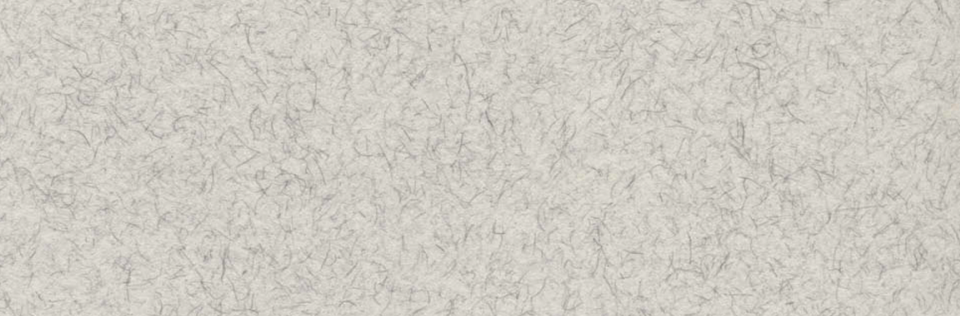

